\title{
Environmental Control Technology for Mining and Milling Low-Grade Uranium Resources
}

\author{
S. A. Weakley \\ D. E. Blahnik \\ L. W. Long \\ C. H. Bloomster
}

April 1981

Prepared for the

Environmental and Safety Engineering Division

U.S. Department of Energy

under Contract DE-AC06-76RLO 1830

Pacific Northwest Laboratory

Operated for the U.S. Department of Energy

by Battelle Memorial Institute 


\title{
NOTICE
}

This report was prepared as an account of work sponsored by the United States Government. Neither the United States nor the Department of Energy, nor any of their employees, nor any of their contractors, subcontractors, or their employees, makes any warranty, express or implied, or assumes any legal liability or responsibility for the accuracy, completeness or usefulness of any information, apparatus, product or process disclosed, or represents that its use would not infringe privately owned rights.

The views, opinions and conclusions contained in this report are those of the contractor and do not necessarily represent those of the United States Government or the United States Department of Energy.

\author{
PACIFIC NORTHWEST LABORATORY \\ operated by \\ BATTELLE \\ for the \\ UNITED STATES DEPARTMENT OF ENERGY \\ Under Contract DE-AC06-76RLO 1830
}

\author{
Printed in the United States of America \\ Available from \\ National Technical Information Service \\ United States Department of Commerce \\ 5285 Port Royal Road \\ Springfield, Virginia 22151
}

Price: Printed Copy \$

$\therefore$ Microfiche $\$ 3.00$

NTIS

-Pages Selling Price

$\begin{array}{ll}001-025 & \$ 4.00 \\ 026-050 & \$ 4.50 \\ 051-075 & \$ 5.25 \\ 076-100 & \$ 6.00 \\ 101-125 & \$ 6.50 \\ 126-150 & \$ 7.25 \\ 151-175 & \$ 8.00 \\ 176-200 & \$ 9.00 \\ 201-225 & \$ 9.25 \\ 226-250 & \$ 9.50 \\ 251-275 & \$ 10.75 \\ 276-300 & \$ 11.00\end{array}$


S. A. Weak ley
D. E. Blahnik
L. W. Long
C. H. Bloomster

Apri 11981

Prepared for the

Environmental and Safety Engineering Division U.S. Department of Energy

under Contract DE-AC06-76RLO 1830

Pacific Northwest Laboratory

Richland, Washington 99352 



\section{SUMMARY AND RECOMMENDATIONS}

In order to meet the increased demands for uranium oxide $\left(\mathrm{U}_{3} \mathrm{O}_{8}\right)$ that will occur in the future, new low-grade domestic deposits will have to be mined. This study examined the type and level of wastes that would be generated in the mining and milling of $\mathrm{U}_{3} \mathrm{O}_{8}$ from four potential domestic sources of uranium. The estimated costs of the technology to control these wastes to different degrees of stringency are presented.

The incremental cost for the control of waste from $\mathrm{U}_{3} \mathrm{O}_{8}$ production could vary not only with the level of control but from site to site (see Table 1). The minimum incremental cost of environmental control technology per pound of $\mathrm{U}_{3} \mathrm{O}_{8}$ ranges from $\$ 22$ at the Thomas Caldera and the Chattanooga shale deposits to $\$ 11$ at the Florida phosphate deposit. These figures represent the minimum cost of meeting present regulations. The maximum incremental cost of environmental control technology per pound of $\mathrm{U}_{3} \mathrm{O}_{8}$ ranges from $\$ 1343$ at the Florida phosphate and Thomas Caldera deposits to $\$ 903$ at the Chattanooga shale deposit. The major difference between the minimum and maximum costs are the methods used to control the mill tailings. The minimum cost alternative is a clay core dam without any pond liner while the maximum cost alternative is to dewater the tailings, blend them with $40 \%$ asphalt, and pump the mixture to a landfill pit or mound. The annual cost of the latter method is very high due to the cost of the asphalt material. The differences between the costs at the four sites at both the maximum and minimum levels of control

TABLE 1. Incremental Environmental Control Technology (ECT) Costs for Four Low-Grade Uranium Deposits

\begin{tabular}{|c|c|c|}
\hline & $\begin{array}{l}\text { Minimum } \\
\text { ECT Cost }\end{array}$ & $\begin{array}{l}\text { Maximum } \\
\text { ECT Cost }\end{array}$ \\
\hline Location & $\$ / 1 \mathrm{~b} \quad U_{3} \mathrm{O}_{8}$ & $\$ / 1 \mathrm{~b} \quad U_{3} \mathrm{O}_{8}$ \\
\hline Chattanooga Shale, Tennessee & 22 & 903 \\
\hline Bokan Mountain, Alaska & 21 & 1309 \\
\hline Thomas Caldera, Utah & 22 & 1343 \\
\hline Phosphates, Central Florida & 11 & 1343 \\
\hline
\end{tabular}


are caused by the amount of ore processed and the treatment process for the tailings from the mine and mill. These differences, as well as many others among the other sites, cause the environmental control technology costs to be highly site-and-process-specific.

The major wastes generated at most sites would be similar in type (dust, water, etc.), but the radioactive content would vary, depending on the ore grade. The major cost would be for controlling the waste water and tailings from the mines and mills. The type of control method that would be used depends on the water volume and its radioactivity level. Waste water control consists of tailings ponds, pond covers, beach dust control, and, in some cases, dewatering and material additions to immobilize the radioactive constituents.

This study indicated that most of the environmental control technology costs (up to 90\%) at each site would be for the control of mill tailings. The unit costs would be lower in all cases if the throughput rates and/or ore grades were higher. It could cost over an order of magnitude more to reduce the amount of a specific waste released by the last 1 or $2 \%$. The technologies examined in this study have the potential to effectively hold the discharge of wastes to very low levels.

There is a lack of data dealing with the wastes from low-grade uranium mining and milling. Most of the environmental control technology data deals with much more radioactive waste streams than are present in this study. If the development of the above deposits becomes probable, research should be undertaken to:

- Obtain site-specific data from the deposit to be developed (e.g., ore analysis, hydrology, ecology, etc.).

- Define flow sheet and processes for the specific sites more accurately.

- Analyze the radon concentrations and retention parameters likely to be encountered in mines and tailings piles at these deposits. Perhaps less stringent methods than assumed in this study may be used for the low-grade ore tailings. 
- Evaluate the performance characteristics of environmental control technology at the waste levels to be encountered at the sites under study.

- Assess the technology and environmental control effectiveness of backfilling underground mines with tailings in greater detail.

- Develop lower cost technologies for long-term storage and stabilization of mill tailings.

- Develop milling processes and tailings control technology that reduce water consumption in arid mining regions. 


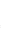




\section{CONTENTS}

SUMMARY AND RECOMMENDATIONS

1.0 INTRODUCTION .

1.1

2.0 SCOPE AND METHODOLOGY

2.1

REFERENCES

3.0 BLACK SHALES • •

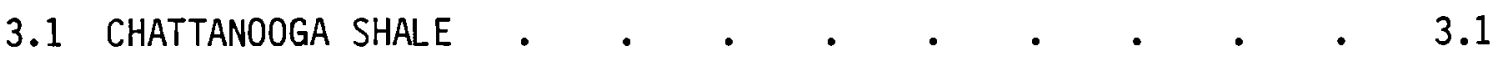

3.1.1 Geography and Demography . . . . . . . 3.1

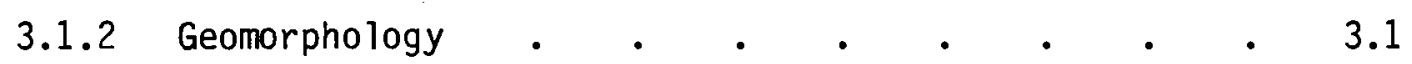

3.1 .3 Meteorology . . . . . . . . . . 3.3

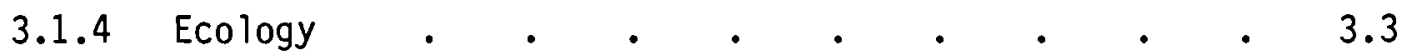

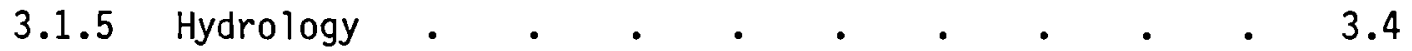

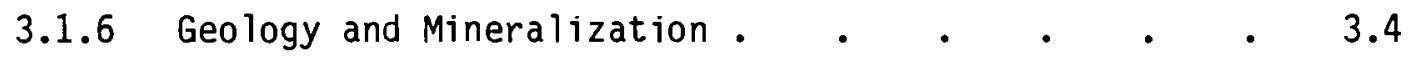

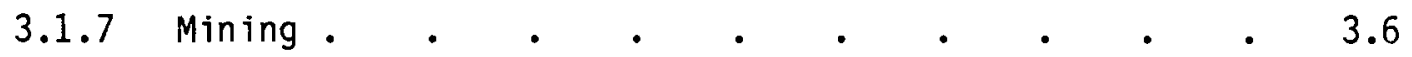

3.1.8 Mining Generated Wastes and Controls . . . . 3.7

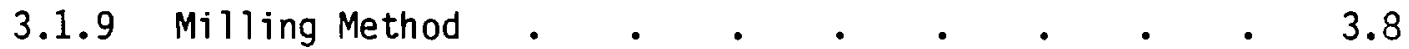

3.1.10 Milling Generated Wastes and Controls . . . 3.11

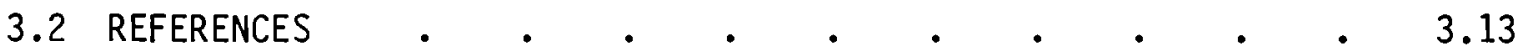

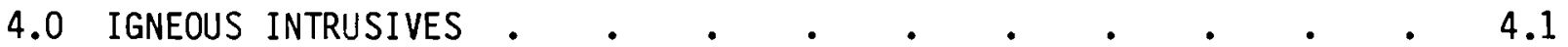

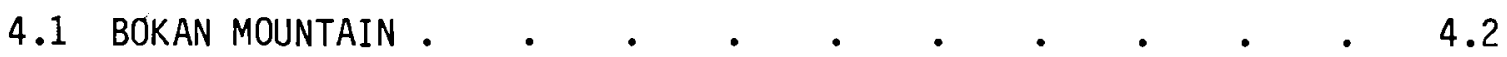

4.1.1 Geography and Demography . . . . . . 4.2

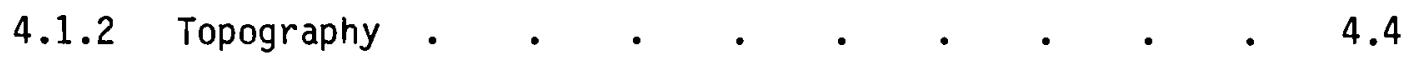

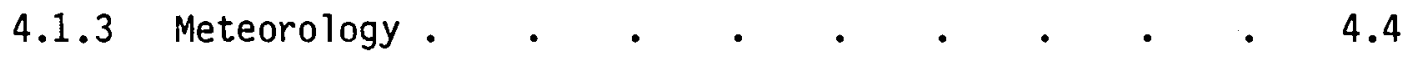

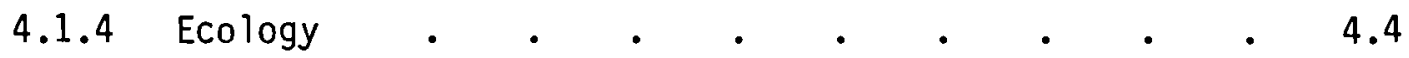

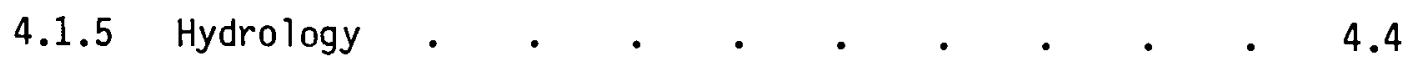


4.1.6 Geology and Mineralization . . . . . . . 4.5

4.1.7 Mining . . . . . . . . . . . . 4.6

4.1.8 Mining Generated Wastes and Controls . . . . 4.6

4.1.9 Milling Method . . . • . . . • . 4.7

4.1.10 Milling Generated Wastes and Controls • . • 4.11

4.2 REFERENCES . • . . . . . . . . . . . . 4.12

5.0 VOLCANIC DEPOSITS

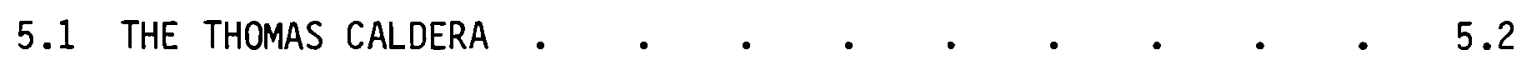

5.1.1 Geography and Demography . • . . . . 5.2

5.1 .2 Geomorphology . . . . . . . . . 5.4

5.1 .3 Meteorology . . . . . . . . . . 5.4

5.1 .4 Ecology $. \quad . \quad . \quad . \quad . \quad . \quad . \quad . \quad .5 .5$

5.1 .5 Hydrology $. \quad . \quad . \quad . \quad . \quad . \quad . \quad . \quad .5 .5$

5.1 .6 Geology and Mineralization . . . . . 5.5

5.1 .7 Mining . . . . . . . . . . . . 5.6 .

5.1.8 Mining Generated Wastes and Controls . • • . 5.6

5.1 .9 Milling Methods • . • • • • • • 5.7

5.1.10 Milling Generated Wastes and Controls . $\quad . \quad 5.10$

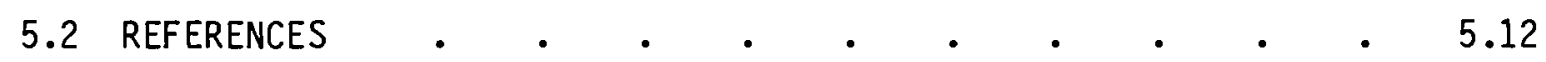

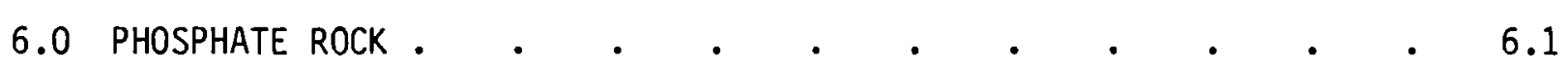

6.1 CENTRAL FLORIDA PHOSPHATE DISTRICT • • • • • • • 6.2

6.1 .1 Geography and Demography . • . . . . 6.2

6.1 .2 Geomorphology • • • • • • • • 6.2

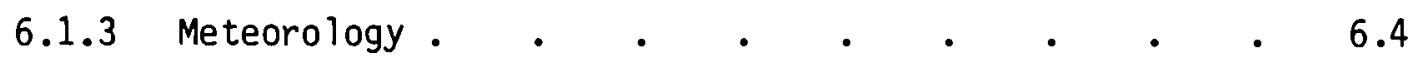

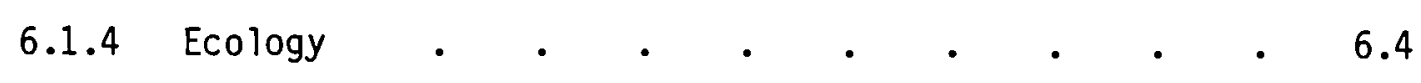

6.1 .5 Hydrology $. \quad . \quad . \quad . \quad . \quad . \quad . \quad . \quad .6 .5$ 
6.1.6 Geology and Mineralization . . . . . . 6.5

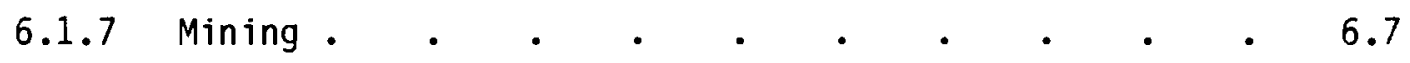

6.1.8 Mining Generated Wastes and Controls . . . . 6.8

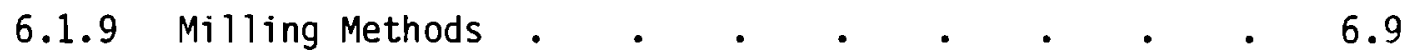

6.1.10 Milling Generated Wastes and Controls . . . 6.11

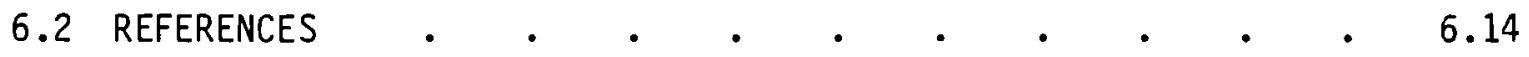

7.0 ASSESSMENT OF AVAILABLE ENVIRONMENTAL CONTROL TECHNOLOGIES • • 7.1

7.1 METHODS OF ENVIRONMENTAL CONTROL FOR MINING $\quad$ • $\quad$ • $\quad$ • 7.2

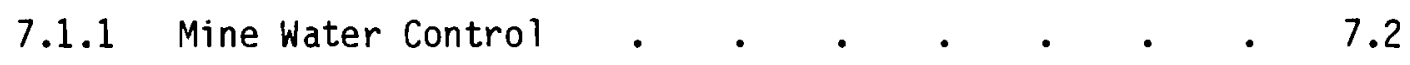

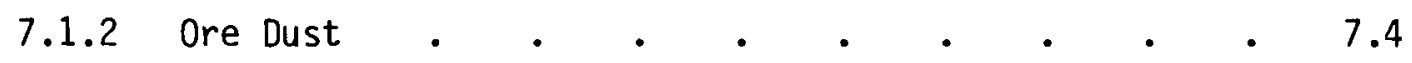

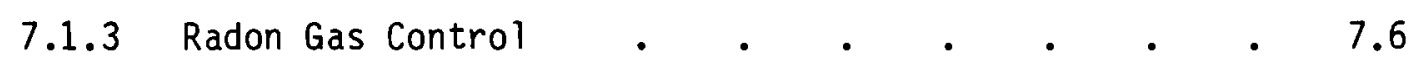

7.1.4 Control of Equipment-Generated Fumes • • • • 7.7

7.2 METHODS OF ENVIRONMENTAL CONTROL FOR MILLING URANIUM • $\quad 7.7$

7.2.1 Control of Mill Dust from Unloading,
Crushing, and Grinding Ore . . . . . . $\quad 7.8$

7.2.2 Control of Dust from Drying, Ignition,
and Packaging Uranium Concentrate . . . . $\quad$. 7.16

7.2.3 Control of Radon Gas from Unloading,
Crushing, and Grinding . . . . . . . $\quad$. 7.17

7.2 .4 Process Fume Control • • • • • • • 7.17

7.2 .5 Tailings Seepage Control • • • • • • • 7.17

7.2.6 Tailings Pond Beach Dust Control . • • • 7.22

7.2.7 Tailings Pond Radon Gas Control • . • . . 7.23

7.2.8 Long-Term Stabilization of the Tailings . $\quad$ • 7.23

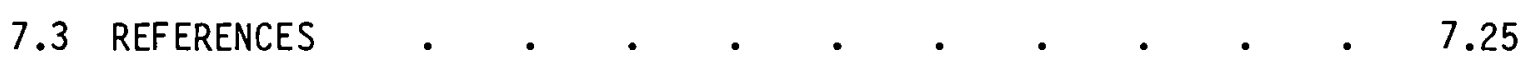

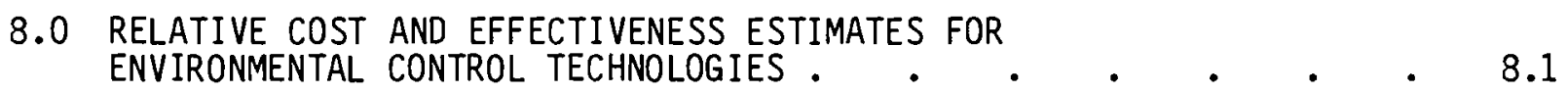


8.1 COST ESTIMATES FOR ENVIRONMENTAL CONTROL TECHNOLOGIES • $\quad 8.13$

8.1.1 Capital Installation Cost . . . . . . 8.14

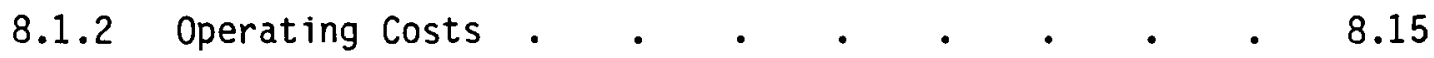

8.1.3 Equivalent Annual Charge for Depreciable
Capital Investment . . . . 8.16

8.1.4 Equivalent Annual Charge for Nondepreciable
Capital Investment $. \quad . \quad . \quad 8.17$

8.1 .5 Annual Cost . . . . . . . . . . . 8.17

8.2 EFFECTIVENESS ESTIMATES FOR ENVIRONMENTAL
CONTROL TECHNOLOGIES..
.

8.2.1 Control of Airborne Dust from Production
Equipment $. \quad . \quad . \quad . \quad . \quad ~$

Control of Airborne Dust from Roads and . . . 8.18
Yards

8.2.3 Control of Airborne Dust from Ore
Storage Piles . $. \quad . \quad . \quad . \quad ~$

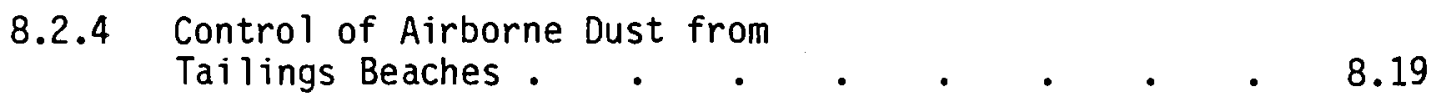

8.2.5 Mine Water Control . . . . . . . . 8.19

8.2.6 Control of Tailings Pond Seepage . . . . 8.19

8.2.7 Tailings Covers . . . . . . . . 8.20

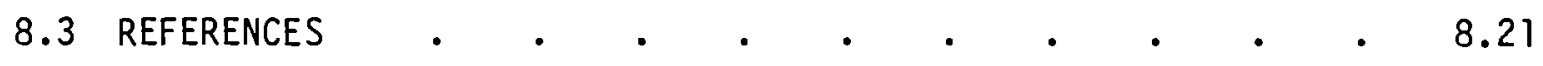

APPENDIX A: RADIOLOGICAL DATA $\quad$ •

A.1 SPECIFIC ACTIVITIES • • • • • • • • • • . A.1

A.2 MAXIMUM PERMISSIBLE CONCENTRATION AND
RELATIVE RADIOTOXICITY..$\quad$. . . . . . . . A.2

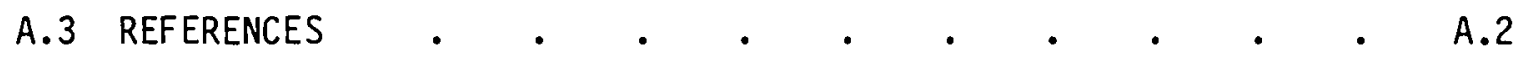

APPENDIX B: MINE GENERATED WASTES . . . . . . . . . . . B. 1

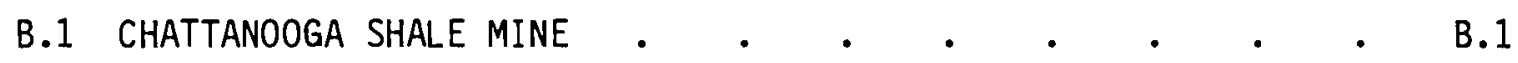




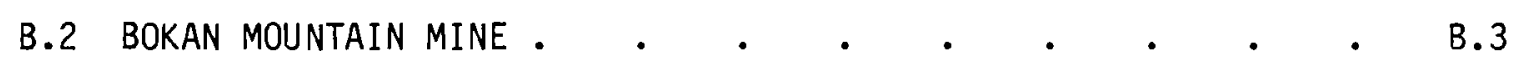

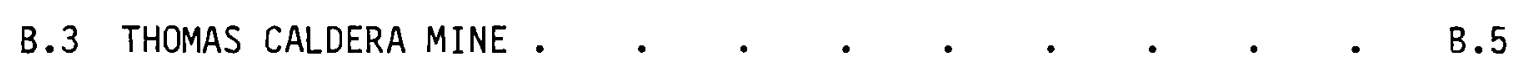

B.4 FLORIDA PHOSPHATE MINE $\quad$ • $\quad$ •

APPENDIX C: MILL GENERATED WASTES •

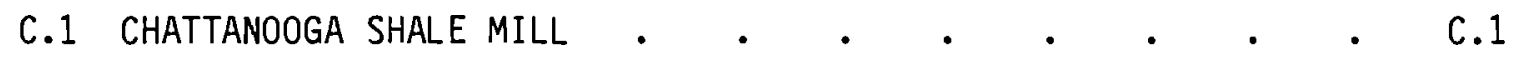

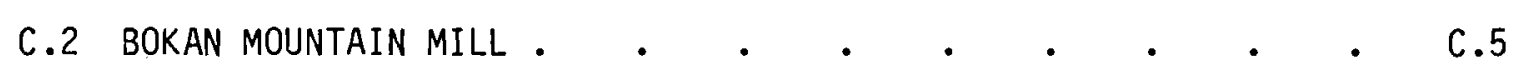

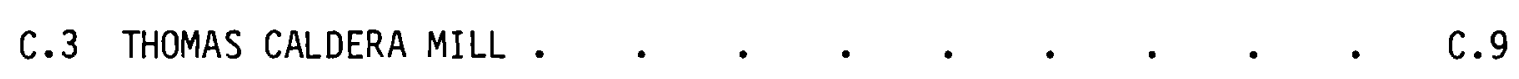

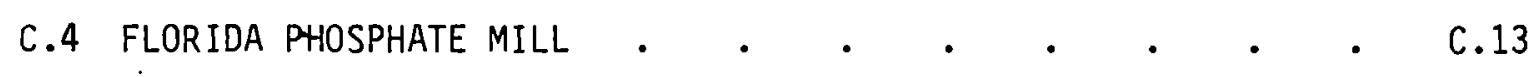





\section{FIGURES}

3.1 Chattanooga Shale Area, Dekalb County, Tennessee . $\quad$ • $\quad$ • 3.2

3.2 Chattanooga Shale Mine and Mill Generated Wastes . . . . 3.10

4.1 Bokan Mountain Area . . . . . . . . . . . . 4.3

4.2 Bokan Mountain Mine and Mill Generated Wastes . . . . 4.9

5.1 Thomas Caldera Area . . . . . . . . . . . . . 5.3

5.2 Thomas Caldera Mine and Mill Generated Wastes $\quad$ • $\quad$ • $\quad$ • 5.9

6.1 Florida Phosphate Areas .

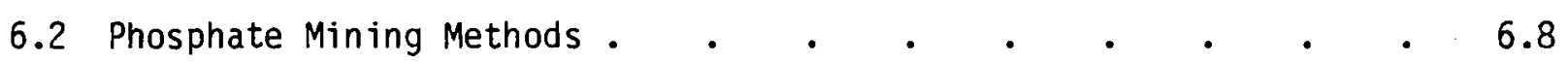

6.3 Florida Phosphate Mill Generated Wastes . . . . . . . 6.10

\begin{tabular}{l}
7.1 Typical Types of Wastes from Mining and Milling \\
of Uranium \\
\hline
\end{tabular}

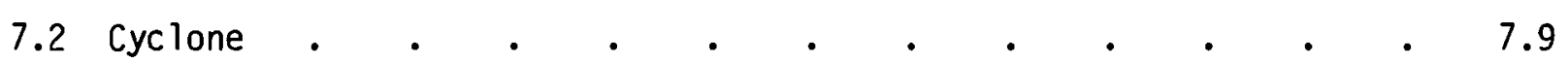

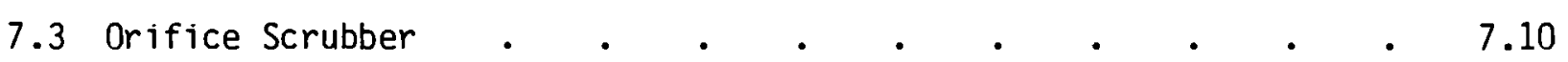

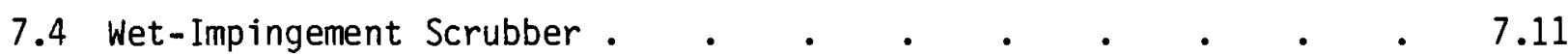

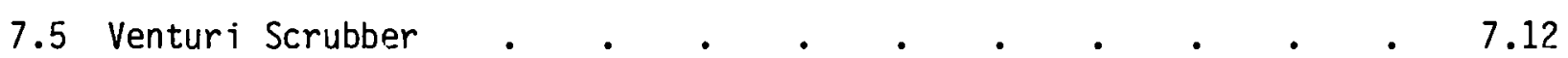

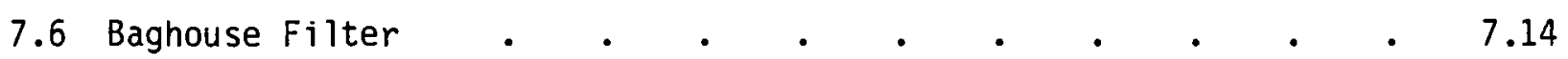

7.7 HEPA FIlter and Manifold Housing for Multiple Filters . • . 7.15

8.1 Mill Unloading, Crushing, and Grinding Dust Collection
Capital Costs as a Function of Efficiency $. \quad . \quad . \quad . \quad . \quad 8.14$

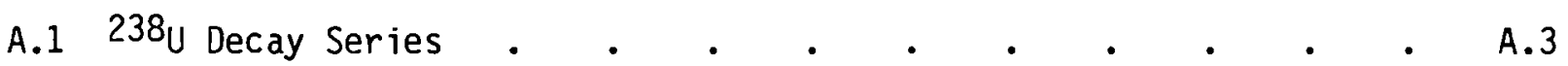

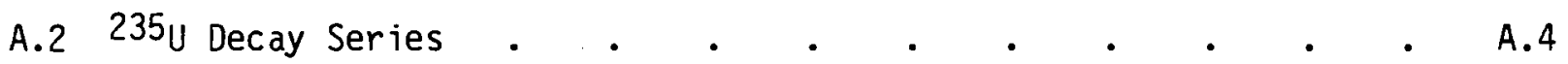

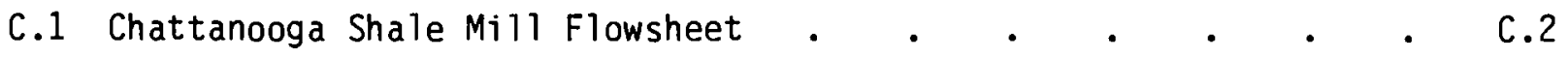

C.2 Bokan Mountain Mill . . . . . . . . . . . . . . . C.6

C.3 Thomas Caldera Mill Flowsheet . • . . . . . . . . C.10

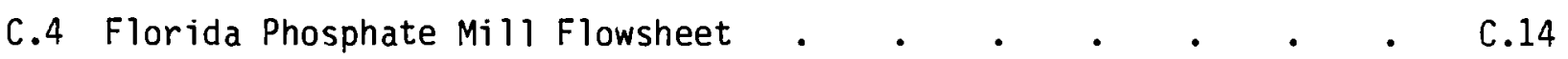





\section{$\underline{\text { TABLES }}$}

1 Incremental Environmental Control Technology Costs

for Four Low-Grade Uranium Deposits

2.1 Major Historic Uranium Producing Environments $\quad$ • $\quad$ e $\quad$ e $\quad$ e 2.1

3.1 Regional Temperature Inversions Over the Chattanooga Shale Area

3.2 Groundwater Quality in Dekalb County, Tennessee . $\quad$ • $\quad$ • 3.5

3.3 Average Mineral Composition of the Chattanooga Shale.$\quad$. $\quad 3.5$

3.4 Estimated Waste Control Costs for Chattanooga Shale Mines and Mill. . . . . . . . . . . . . 3.9

4.1 Principal Minerals of the Bokan Mountain Intrusive Plug . $\quad 4.5$

4.2 Estimated Waste Control Costs for Bokan Mountain

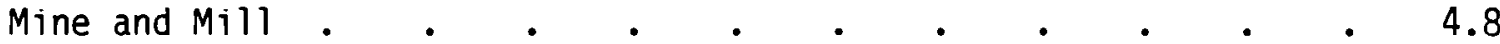

5.1 Afternoon Ventilation Data for the Thomas Range . . . . 5.4

5.2 Sandstone Host Rock Composition, Yellow Chief Mine . $\quad . \quad 5.5$

5.3 Estimated Waste Control Costs for Thomas Caldera Mine and Mill .

6.1 Demography of the Central Florida Phosphate District $\quad$ • $\quad$ e 6.4

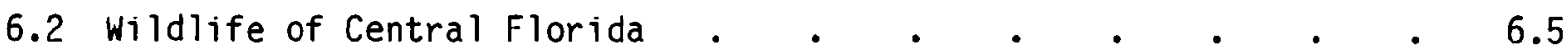

6.3 Significant Minerals in Marine Phosphorite $\quad$ • $\quad . \quad$. $\quad$. 6.6

6.4 Specifications of a Typical Florida Phosphate

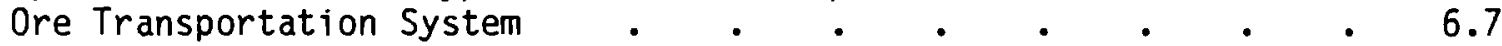

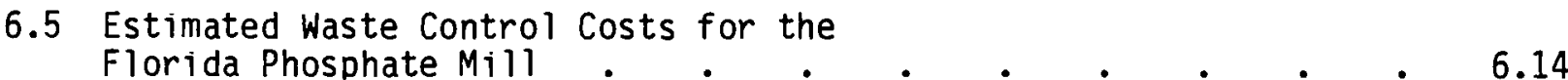

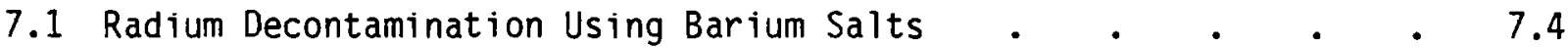

8.1 Cost Range for Environmental Control for the Mining
and Milling of Various Uranium Resources $. . \quad . \quad . \quad 8.2$

8.2 Cost and Effectiveness of Environmental Control Technologies at the Chattanooga Shale Mine and $\mathrm{Mil}$ 
8.3 Cost and Effectiveness of Environmental Control Technologies at the Bokan Mt. Mine and Mill . . . . $\quad$. 8.7

8.4 Cost and Effectiveness of Environmental Control Technologies at Thomas Caldera Mine and Mill . $\quad$. $\quad$. $\quad$. 8.9

8.5 Cost and Effectiveness of Environmental Control Technologies at the Florida Phosphate Mine and Mill $\quad . \quad$ e $\quad$. $\quad 8.11$

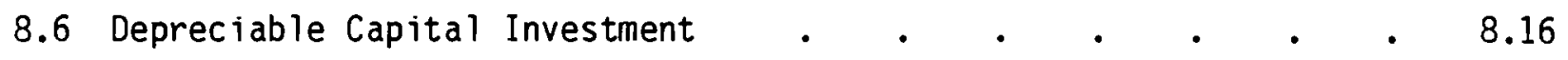

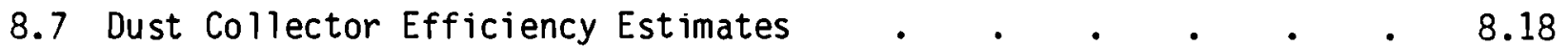

8.8 Estimated Effectiveness of Various Methods of Seepage Control

A.1 Maximum Permissible Concentration of Radionuclides in Air and Water

A. 5 


\subsection{INTRODUCTION}

During the past few years, an increased demand for uranium has caused significantly higher prices for uranium oxide. This has resulted in an increased exploration effort to define additional conventional uranium resources and to reinvestigate uranium resources previously classified as uneconomical. Bringing new mineral regimes into production will result in unique environmental control problems and require technologies heretofore unencountered.

The purpose of this report is to evaluate, in terms of cost and effectiveness, the various environmental control technologies that would be used to control the radioactive wastes generated in the mining and milling of domestic low-grade uranium resources. To be considered for study, the technologies had to reduce the radioactivity of the waste streams to meet Code of Federal Regulations (10 CFR 20) Standards for maximum permissible concentration (MPC) of $U_{238}$ in air and water. Further regulatory standards or licensing requirements, either federal, state, or local, were not examined.

A recent Nuclear Regulatory Commission (NRC) report, the Final Generic Environmental Impact Statement on Uranium Milling (September 1980), which was unavailable during the research section of this study, deals with the environmental effects and cost of controlling radioactive wastes from milling highgrade ore. This study, however, deals only with very low-grade ore $1<0.01 \%$ $\mathrm{U}_{3} \mathrm{O}_{8}$ ) and is not a comprehensive environmental impact statement.

The objectives of this study are: 1) to identify the potential new domestic sources of low-grade uranium that may be developed in the near future, 2) to describe the mining and milling processes for the identified resources and the major waste streams generated from these processes, and 3) to determine the cost and levels of control of existing and advanced environmental control technologies for these waste streams.

Four potential deposits of low-grade domestic uranium oxide are identified in Chapter 2 of this report. Each of these deposits is discussed individually in Chapters 3 through 6 . These chapters include a summary of the 
location and characteristics of the resource, a discussion of the mining and milling methods and associated waste streams, and a presentation of the stateof-the-art or base case technologies and costs for controlling the wastes. Chapter 7 assesses the available environmental control technologies for uranium mines and mills. Chapter 8 presents the cost and effectiveness estimates for those environmental control technologies applicable to the mine and mill for each resource. 


\subsection{SCOPE AND METHODOLOGY}

Waste releases and control technologies associated with producing uranium from sandstone deposits have been addressed by other studies. However, recovering uranium from conventional sandstone deposits by new or unconventional means is within the scope of this report.

To determine new uranium mineral regimes that may be of economic significance in the future, it is necessary to examine their economic viability. Economic viability can be broken down to at least 3 components: the grade and physical characteristics of the ore, the prevailing market price, and externalities such as licensing requirements. Because ore grade and physical characteristics are constant, price and extraction technology play a major role in determining if a given resource is feasible to exploit.

Market price tends to dictate minimum cutoff grades and deposit types that can be economically exploited. As a rule this cutoff grade has been well above $0.05 \%$, with most of the free world's uranium being produced from the three geologic environments listed in Table 2.1.

TABLE 2.1. Major Historic Uranium Producing Environments(1)

Deposit Type Grade Range (\%) Average Grade (\%)

$\begin{array}{lll}\text { Lode Veins } & 0.4-1 & \text { N/A } \\ \text { Sandstone } & 0.04-0.4 & 0.17 \\ \text { Conglomerate } & 0.015-0.1 & 0.12\end{array}$

Between 1973 and 1979 the price of yellow cake rose from $\$ 6 / 1 b$ to over $\$ 40 / 1 b$. During that same period the minimum economic grade decreased from $0.15 \%$ to $0.015 \%$. The Department of Energy's National Uranium Resource Evaluation (NURE) project currently evaluates potential uranium ore down to grades of $0.01 \%$. A study recently completed by Pacific Northwest Laboratory (PNL) estimates that the total quantity of recoverable $\mathrm{U}_{3} \mathrm{O}_{8}$ above $0.01 \%$ grade in the U.S. has a $99 \%$ confidence range of 5.51 to $8.93 \mathrm{million}$ short tons with the mean value being 7.07 million tons (7). The PNL report also estimates that $70 \%$ of the $U_{3}{ }^{0} 8$ is available for $\$ 100 / 1 b$ or less and $90 \%$ is available 
for $\$ 175 / 1 b$ or less. Costs of the remaining $10 \%$ rise rapidly to $\$ 500 / 1 b$. Because a majority of the $\mathrm{U}_{3} \mathrm{O}_{8}$ included in the assessment is contained in sandstone or sandstone-like deposits, it is reasonable to assume that the price exceeds $\$ 150 / 1 b$, low grade deposits in different geologic environments will become economically viable.

In addition to the inverse relationship between price and minimum economic grade, other important factors are involved. Economic viability is also a function of:

- size, depth and stripping ratio of the deposits

- mining methods required to extract the ore

- extractive characteristics of the ore

- other factors of capital and operating cost. (8)

Because of these factors, no attempt has been made to define grade classifications or place individual deposits within categories. Consideration is given to all generic mineral environments deemed potentially viable at some future price. Some of the more significant are: $(8,9)$

- black shales

- igneous intrusives

- volcanic deposits

- phosphate rock.

The environmental control technologies of producing uranium from these mineral regimes are addressed and proximate waste releases for each potential mining area are identified. An environmental impact statement format has been adopted to assess potential impacts of mining. Once environmental factors have been identified, a materials flow from in situ ore through the final processing of yellow cake is outlined and waste released at each stage is estimated.

The processes and environmental control technologies necessary to abate generated wastes are conceptualized from current published data. In addition, the relationship between cost and level of waste control technology is identified. This is estimated using existing cost/control relationships. In order to produce a complete document on representative sources of uranium, comprehensive feasibility studies of the National Uranium Resource Evaluation 
Program (NURE) are referenced and abstracted. This is necessary because generally the feasibility studies do not address waste control technology and associated costs.

In a few of the potential mineral environments, actual mining of uranium has been carried out under the government purchase program. Where this has been the case, those specific deposits were assessed in an attempt to characterize the generic mineral regime. The purpose is twofold. First, data on actual processes, even though dated, are usually more relevant than conceptualizations. Second, due to current licensing requirements new mines are more likely to relocate at previously developed areas. Therefore, assessments herein may apply directly to actual specific sites.

\section{REFERENCES}

1. Environmental Protection Agency. 1975. Group II, Development Document for Interim Final and Proposed Effluent Limitation Guidelines and New Source Performance Standards for the Ore Mining and Dressing Industry, EPA 440/1-75/061, Environmental Protection Agency, Washington, D.C.

2. Sears, M. B., et al. 1975. Correlation of Radioactive Waste Treatment Costs and the Environmental Impact of Waste Effluents in the Nuclear Fuel Cycle for Use in Establishing "As Low as Practicable" Guides - Milling of Uranium Ores, ORNL-TM-4903, Vol. 1, Oak Ridge National Laboratory, 0ak Ridge, Tennessee.

3. "Radiation Protection in Mining and Milling of Uranium and Thorium." 1976. Proceedings from International Symposium, held in Bordeaux, France, September 9-11 1974, ISBN 92-2-101504-1, IL0 Publications, $\mathrm{CH}-1211$ Geneva 22, Switzer land.

4. Environmental Protection Agency. 1975. Group II, Development Document for Interim Final and Proposed Effluent Limitation Guidelines and New Source Performance Standards for the Ore Mining and Dressing Industry, EPA 440/1-75061, U.S. Environmental Protection Agency, Washington, D.C.

5. Hendricks, D. W. 1977. Uranium Mill Tailings Storage, Use and Disposal Problems, Paper at Conference on Uranium Mining Technology, April 25-29, 1977, Reno, Nevada.

6. Koehmstedt, P. L., J. N. Hartley and D. K. Davis. 1977. Use of Asphhalt Emulsion Sealants to Contain Radon and Radium in Uranium Tailings. BNWL-2190, Pacific Northwest Laboratory, Richland, Washington. 
7. Piepel, G. F., L. W. Long, R. A. McLaren and C. E. Ford. 1981. Probabilistic Estimates of U.S. Uranium Supply, PNL-3595, Pacific Northwest Laboratory, Richland, Washington.

8. DeVoto, R. L. 1978. Uranium Geology and Exploration, Colorado School of Mines, Golden, Colorado.

9. McGinley, F. E. 1978. "Low-Grade and Byproduct Uranium Resources," presented at the National Uranium Symposium, October 17-18, 1978, Grand Junction, Colorado. 


\subsection{BLACK SHALES}

Significant amounts of low-grade uranium are contained in a stratigraphic unit of black shale occurring in portions of Kentucky, Tennessee, Alabama and Georgia. The Bureau of Mines estimates between 4 and 5 million short tons of $\mathrm{U}_{3} \mathrm{O}_{8}$ are contained in central Tennessee alone. Total uranium contained in all four states may be in the tens of millions of tons.

Commonly referred to as Chattanooga shale, the deposit has been investigated since it was first considered as a potential uranium resource in the early 1950s. $(1,2,3,4,5)$ More recently, the Department of Energy has commissioned a comprehensive three volume feasibility study of the Chattanooga shale as part of the National Uranium Resource Evaluation Program. ${ }^{(6)}$ The relationship between cost and level of environmental control technology has not been completely addressed, and for that reason, brief descriptions will be abstracted here to provide background information for the cost/control technology problem.

\subsection{CHATTANOOGA SHALE}

\subsubsection{Geography and Demography}

The Chattanooga shale is a regional stratigraphic unit covering 35,000 square miles in south central Kentucky, central Tennessee, and portions of northern Alabama and Georgia. Because surface geology indicated favorable mineral concentrations in Dekalb County, Tennessee, that area has been selected for more detailed investigation. Geographic perspective is given in Figure 3.1.

The four state area is typically rural in character. Environmental factors restrict land use to either forest or agriculture uses except where urban centers have developed. Dekalb County, Tennessee has an approximate population of 11,500 or about 41 people per square mile.

\subsubsection{Geomorphology}

Several regional morphologic districts occur in the Chattanooga shale area. In southern Kentucky, the Mississippian Plateau is characterized by low 


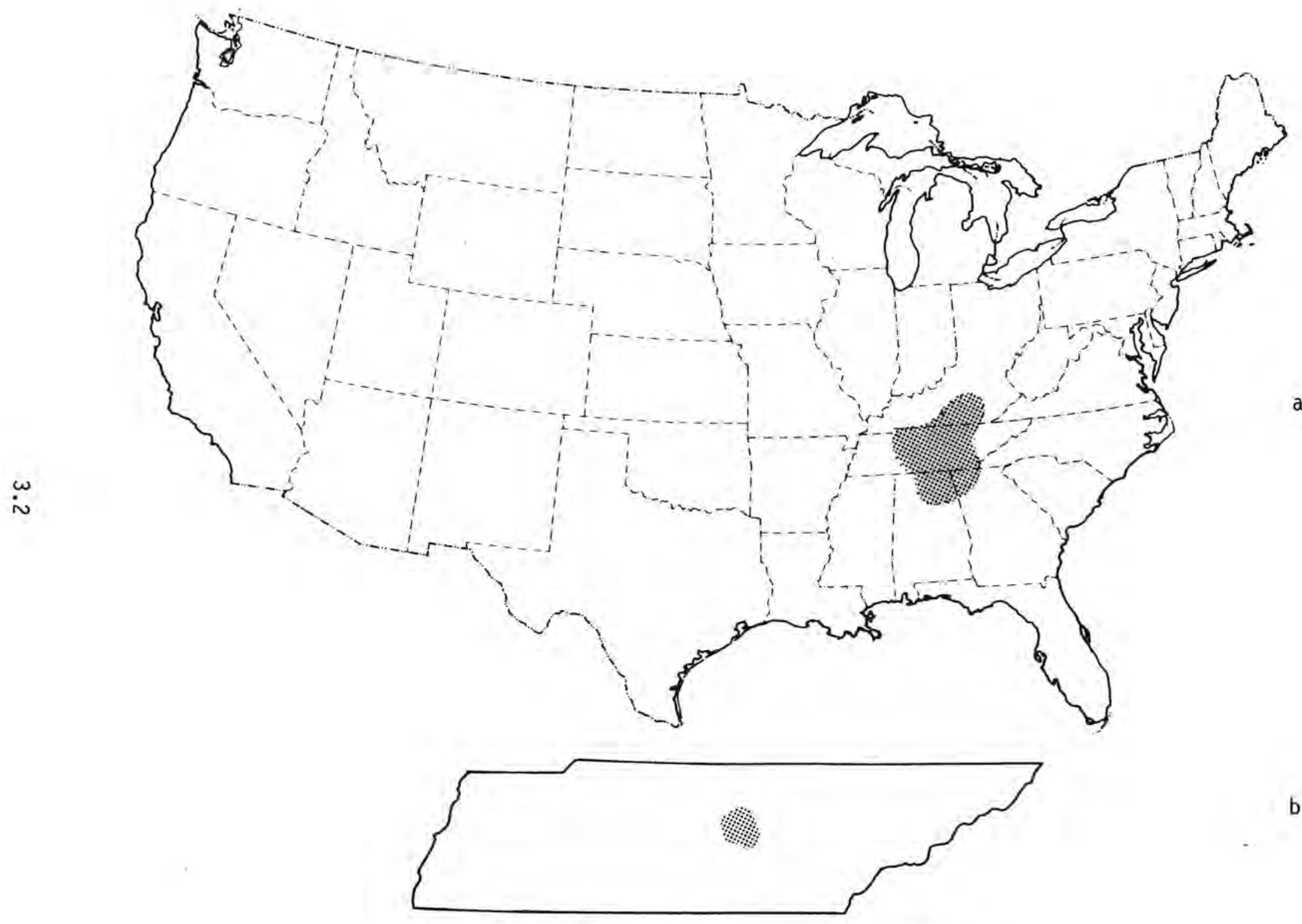

FIGURE 3.1. a. Chattanooga Shale Area

b. Dehalb County, Tennessee 
farmland 600 to $700 \mathrm{ft}$ in elevation. Easterly across central Tennessee, the terrain changes from rolling plains at about $600 \mathrm{ft}$ above sea level in the Nashville Basin to elevations of 1,000 ft along the East Highland Rim. Continuing eastward, the hilly crest of the Cumberland Plateau is 40 miles wide and 2,000 to 3,000 ft high. The Appalachian Valley of northern Alabama and Georgia changes from rolling terrain $400 \mathrm{ft}$ in elevation to hills higher than $1,000 \mathrm{ft}$ at the Cumberland Plateau. Deposits in Dekalb County extend from the Nashville Basin to the East Highland Rim.

\subsubsection{Meteorology}

Because of varying regional topographic features, the Chattanooga shale area displays a wide range of annual precipitation. The lowlands of southern Kentucky receive about $48 \mathrm{in./yr}$ while over $80 \mathrm{in./yr}$ fall in the Smokey Mountains of Tennessee. Northern Alabama and Georgia receive about $56 \mathrm{in./yr}$. Precipitation in Dekalb County averages just over $50 \mathrm{in./yr}$ with $98 \%$ being in the form of rainfall.

Windspeed in the four-state region averages 7 to $10 \mathrm{mph}$. Ventilation over the region, a measure calculated by combining windspeed and mixing depth, is favorable to dispersing pollutants. In a recent 5-year period only 2 days had an index less than $2,000 \mathrm{~m}^{2} / \mathrm{sec}$. Locally, Dekalb County has excellent ventillation due to high wind speeds and good vertical mixing.

Mean annual temperatures throughout the region range from $64^{\circ} \mathrm{F}$ in northern Alabama to $56^{\circ} \mathrm{F}$ around the Cumberland Plateau in Kentucky. Typically, elevation differences change the temperature $2^{0} \mathrm{~F} / 1,000 \mathrm{ft}$. Temperature inversions lead to rapid accumulations of pollutants by trapping rising air. Regional inversion statistics, based on the total number of hours per year of a temperature inversion below $500 \mathrm{ft}$, are shown in Table 3.1 .

\section{1 .4 Ecology}

Because of its rural undeveloped character, a wildlife biome exists in much of the resource area. Generally broadleaf deciduous forests dominate the area of study. Cedar glades and bluestem prairie grasses occupy lowlands. The forests and rivers are occupied by a variety of small mammals, birds, and fish. Recent studies referenced by the Department of Energy feasibility 
TABLE 3.1. Regional Temperature Inversions
Over the Chattanooga Shale Area

$\begin{array}{lc}\text { Season } & \text { Inversion Hours } \\ \text { Winter } & 910 \\ \text { Spring } & 707 \\ \text { Summer } & 994 \\ \text { Fall } & 983 \\ \text { Annual } & 3,594\end{array}$

report indicate man has had a great influence on altering wildlife communities by reducing native environments and changing proximate ecosystems.

\section{1 .5 Hydrology}

The Chattanooga shale area is dissected by numerous surface streams and rivers fed by precipitation runoff, discharge of groundwater, and inflow of streams from adjacent areas. In addition, abundant groundwater is present due to limestone cavities and a thick permeable regolith.

Water quality is often dependent on the lithology of the source aquifer and the amount of organic material entering the runoff flows. Typically, total dissolved solids in surface water of the area varies from 40 to $200 \mathrm{mg} / 1$, while hardness varies from 20 to $150 \mathrm{mg} / 1$. Because much of the groundwater percolates through limestone and dolomite, it tends to be hard and slightly alkaline. Groundwater pH is generally 7.5 to 8.0. Dissolved minerals in both groundwater and surface water are dominated by calcium and bicarbonate. Data on groundwater quality in Dekalb County are listed in Table 3.2. Because the Chattanooga shale has a high organic content, groundwater in contact with it generally contains dissolved hydrogen sulfide and natural gas.

\subsubsection{Geology and Mineralization}

Deposited in a late Devonian marine environment, the Chattanooga shale stratigraphic unit ranges from 0 to $30 \mathrm{ft}$ thick but typically has a uniform thickness of about $15 \mathrm{ft}$. Although several subunits have been identified, 
TABLE 3.2. Groundwater Quality in Dekalb

County, Tennessee (ppm)

Constituent

Sulfate

Sodium Chloride

Total Hardness

Silica

Alkalinity

Total Dissolved Solids

Iron

\section{Concentration}

51

143

183

8

186

442

0.18

generally the rock is a black-brown, laminated, very fine-grained shale with pyrite concretions. Stratigraphically the shale is immediately overlain by approximately $2 \mathrm{ft}$ of claystone interbedded with phosphate nodules. The uppermost member in the geologic column is a competent argillaceous and siliceous limestone over $200 \mathrm{ft}$ thick. Mineral composition of the shale is given in Table 3.3.

TABLE 3.3. Average Mineral Composition of the Chattanooga Shale

\begin{tabular}{lr}
\multicolumn{1}{c}{ Mineral } & \multicolumn{1}{c}{} \\
\hline Illite and Kaolinite & 31 \\
Quartz & 22 \\
Organic Matter & 22 \\
Pyrite and Marcasite & 9 \\
Feldspar & 2 \\
Chlorite & 2 \\
Iron Oxides & 1 \\
Tourmaline, Zircon, Apatite & 100 \\
$\quad$ Total &
\end{tabular}


Uranium has been absorbed by plant life from seawater in a reducing marine environment and is now trapped in amorphous bituminous organic matter. Because of the amorphous form it has been difficult to identify specific uranium minerals. On a regional average, the upper member of the Chattanooga shale contains about $60 \mathrm{ppm}$ uranium $\left(71 \mathrm{ppm} U_{3} 0_{8}\right)$. Also, it is estimated each ton of shale can contain as much as 21.7 gal of crude 011 . In addition, numerous trace elements are present in concentrations greater than the crustal average.

Complete resource estimates on a regional basis are lacking. The U.S. Bureau of Mines has estimated between 4.2 to $5.1 \mathrm{million}$ short tons of in situ . uranium are contained in a 12 county area in central Tennessee. (7) Exploratory drilling in an 18 square mile area of Dekalb County has established approximately 33,000 short tons of proved uranium reserves contained in $595 \mathrm{million}$ tons of shale averaging $55 \mathrm{ppm} \mathrm{U}_{3} \mathrm{O}_{8}$.

Note that there is no special reason to infer Dekalb County contains any more favorable deposits than the other 11 counties investigated or the entire four state resource area. The shale is a remarkably uniform geologic unit and may well display similar uranium concentrations over large areas. Dekalb County was selected for more detailed evaluation because of favorable surface geology.

Detailed descriptions of the prevailing geology and resource estimates as well as estimating techniques are available in earlier investigations. $(6,7)$ 3.1 .7 Mining $^{(6)}$

Mining of Chattanooga shale is currently in the conceptual stages. However, several factors unique to the stratigraphy will greatly influence mining methods. The factors and mining methods recommended by the Department of Energy feasibility study will be summarized.

Because the ore is low-grade, surface mining would seem to be the most economic method. However, the uranium-bearing layer is only $20 \mathrm{ft}$ thick and is buried beneath over $200 \mathrm{ft}$ of hard silica limestone, therefore strip mining is not feasible. In situ leaching to recover minerals would eliminate stripping and minimize other environmental problems. However, the fine-grained 
impermeability of shale inhibits this process to the point where current state-of-the-art leaching methods would not be economical.

At present, underground mining is the only feasible alternative. The hard limestone makes a good roof and requires minimal support. Also, when consideration is given to the recovery of $0 i 1$ and trace elements as well as uranium, underground mining becomes more economical. Three underground mines with a total production of $\simeq 100,000$ tons/day are planned. Each conceptual mine calls for a room and pillar system with a capacity of 36,000 tons/day. Overall extraction ratios are estimated to be $60 \%$. A conveyor belt system would bring ore to the surface. Mining would proceed down dip with an estimated $70 \%$ of tailings being backfilled.

\subsubsection{Mining Generated Wastes and Controls}

The solid waste from the three conceptual mines consists of low-grade wall rock and gangue material. Due to its low level of radioactivity, the waste rock is assumed to be used on-site, either as road material or as backfill in the mine. The solid waste is not seen as posing any threat external to the mine site.

The liquid wastes from the mines are influenced by a number of subsurface hydrologic conditions including the proximity of mine shafts to subsurface aquifers and the size of these aquifers. The amount of water removed from each mine is $5,000 \mathrm{gpm}$. The average $U_{3} 0_{8}$ concentration from presently operating uranium mines is $12.5 \mathrm{ppm}$. Since the ore concentration of presently operating mines is far greater than the $65 \mathrm{ppm}$ of the Chattanooga shale ore, the average concentration of $\mathrm{U}_{3} \mathrm{O}_{8}$ in the mine water is assumed to be $1 \mathrm{ppm}$ or $1 \mathrm{mg} / 1$, which is probably an upper estimate.

The mine water is the most radioactive waste generated at the Chattanooga shale mines. A 7.5 acre settling pond for each mine is needed to control the mine water. This pond will allow the fines to settle out before the water is released. The capital cost of each pond is $\$ 1,859,000$ and the operating cost is $\$ 802,000$ per year.

Water from the mines is used in the mill process as needed and excess mine water is discharged into surface waters. After several years of mill 
operation the leaching and decantation tailings will be disposed of in mined out areas. The tailings slurry will be pumped to the mine for disposal, and any excess water will be returned to the mill.

Dust originates at two areas in each mine. Approximately one quarter of the dust is generated in the underground mine. Most of the dust $(\simeq 3 / 4)$ originates in aboveground mine operations, such as loading and transporting the mined ore to the mill and storing the ore at the mine site.

Dust in the underground mines can be completely controlled by the $1,600,000-c f m$ ventilation system required in each mine for health and safety. Dust collectors are usually not needed because the dust stream is dilute enough to be released directly to the atmosphere with current regulations (10 CFR 20). Thus, the cost of dust control in the underground mine is zero. The cost of the ventilation system is included as part of overall capital cost.

Aboveground dust is controlled by wetting down roads, yards, and storage piles. Barriers are also required around the ore storage piles. Major control costs are for aboveground dust control measures, are shown in Table 3.4. 3.1 .9 Milling Method (6)

The Chattanooga shale mill processes $0.0065 \% \mathrm{U}_{3}{ }_{8}$ ore and produces $90 \%$ $\mathrm{U}_{3} \mathrm{O}_{8}$ powder. At the same time 8,524 tons/day of synthetic crude 0il are also recovered. The hydroretorting of the shale to separate the syncrude from the ore is not shown in Figure 3.2 but would take place after the crushing and grinding point in the flowsheet. The hydroretorting process and the $0 i 1$ recovery steps are not analyzed because we are interested solely in the recovery of $\mathrm{U}_{3} \mathrm{O}_{8}$. The rest of the process after the hydroretorting step is not appreciably affected by oil removal and would be as shown in Figure 3.2 .

The crushing and grinding step has two stages. First the ore is fine crushed to $1 / 4 \mathrm{in}$. and then is ground to 48 -mesh in dry ball mills. The ore is then slurried to $50 \%$ solids and leached with sulfuric acid. Approximately $60 \%$ of the uranium will dissolve in the leach stage of the process. This process takes place in mechanical agitators with 6 hours retention time. 
TABLE 3.4. Estimated Waste Control Costs for Chattanooga Shale Mines and Mill

\begin{tabular}{|c|c|c|c|}
\hline Generated Wastes & Type of Control & $\begin{array}{l}\text { Capital } \\
\text { Cost }(\$ 1000) \\
\end{array}$ & $\begin{array}{c}\text { Annual } \\
\text { Cost }(\$ 1000) \\
\end{array}$ \\
\hline \multicolumn{4}{|l|}{ Mine } \\
\hline Mine Water & $\begin{array}{l}\text { 7.5-acre settling pond, } \\
\text { ditches, etc. }\end{array}$ & 1,860 & 800 \\
\hline $\begin{array}{l}\text { Underground Mine } \\
\text { Dust }\end{array}$ & $\begin{array}{l}1,600,000-c f m \text { ventila- } \\
\text { tion system }\end{array}$ & 0 & 0 \\
\hline $\begin{array}{l}\text { Aboveground Mine } \\
\text { Dust }\end{array}$ & $\begin{array}{l}\text { Spray equipment and wind } \\
\text { barriers }\end{array}$ & 225 & 170 \\
\hline \multicolumn{4}{|l|}{ Mi11 } \\
\hline $\begin{array}{l}\text { Dust from Unloading, } \\
\text { Separation, Crushing } \\
\text { and Grinding }\end{array}$ & $\begin{array}{l}2-50,000-c f m \text { cyclone } \\
\text { collector systems }\end{array}$ & 70 & 50 \\
\hline $\begin{array}{l}\text { Drying and Ignition } \\
\text { Dust }\end{array}$ & $\begin{array}{l}8000 \text {-cfm wet impingement } \\
\text { scrubber system }\end{array}$ & 18 & 10 \\
\hline Packaging Dust & $\begin{array}{l}2000-c f m \text { baghouse filter } \\
\text { system }\end{array}$ & 13 & 6 \\
\hline $\begin{array}{l}\text { Dry Tailing from } \\
\text { Unloading and } \\
\text { Separation }\end{array}$ & $\begin{array}{l}320 \text {-acre landfill with } \\
\text { stacker and conveyor } \\
\text { system }\end{array}$ & 8,400 & 3,900 \\
\hline $\begin{array}{l}\text { Dry Tailings } \\
\text { Radioactivity }\end{array}$ & $\begin{array}{l}6-\mathrm{ft} \text { earth cover and } \\
\text { vegetation ( } 320 \text { acres) }\end{array}$ & 2,900 & 28 \\
\hline \multirow[t]{2}{*}{ Liquid Waste } & $\begin{array}{l}925 \text {-acre clay core dam and } \\
\text { tailings pond system }\end{array}$ & 26,700 & 14,600 \\
\hline & $\begin{array}{l}\text { Pump tailings to mine and } \\
\text { recover water }\end{array}$ & 62,800 & 34,800 \\
\hline $\begin{array}{l}\text { Tailings Pond } \\
\text { Radioactivity }\end{array}$ & $\begin{array}{l}6-\mathrm{ft} \text { earth cover and } \\
\text { vegetation ( } 925 \text { acres) }\end{array}$ & 8,300 & 80 \\
\hline Mine Radioactivity & $\begin{array}{l}\text { Seal mine after mill } \\
\text { shutdown }\end{array}$ & 2,000 & 20 \\
\hline $\begin{array}{l}\text { Tailings Pond Beach } \\
\text { Dust }\end{array}$ & Portable spray equipment & 95 & 170 \\
\hline Total Costs & & 113,381 & 54,600 \\
\hline
\end{tabular}

\section{9}




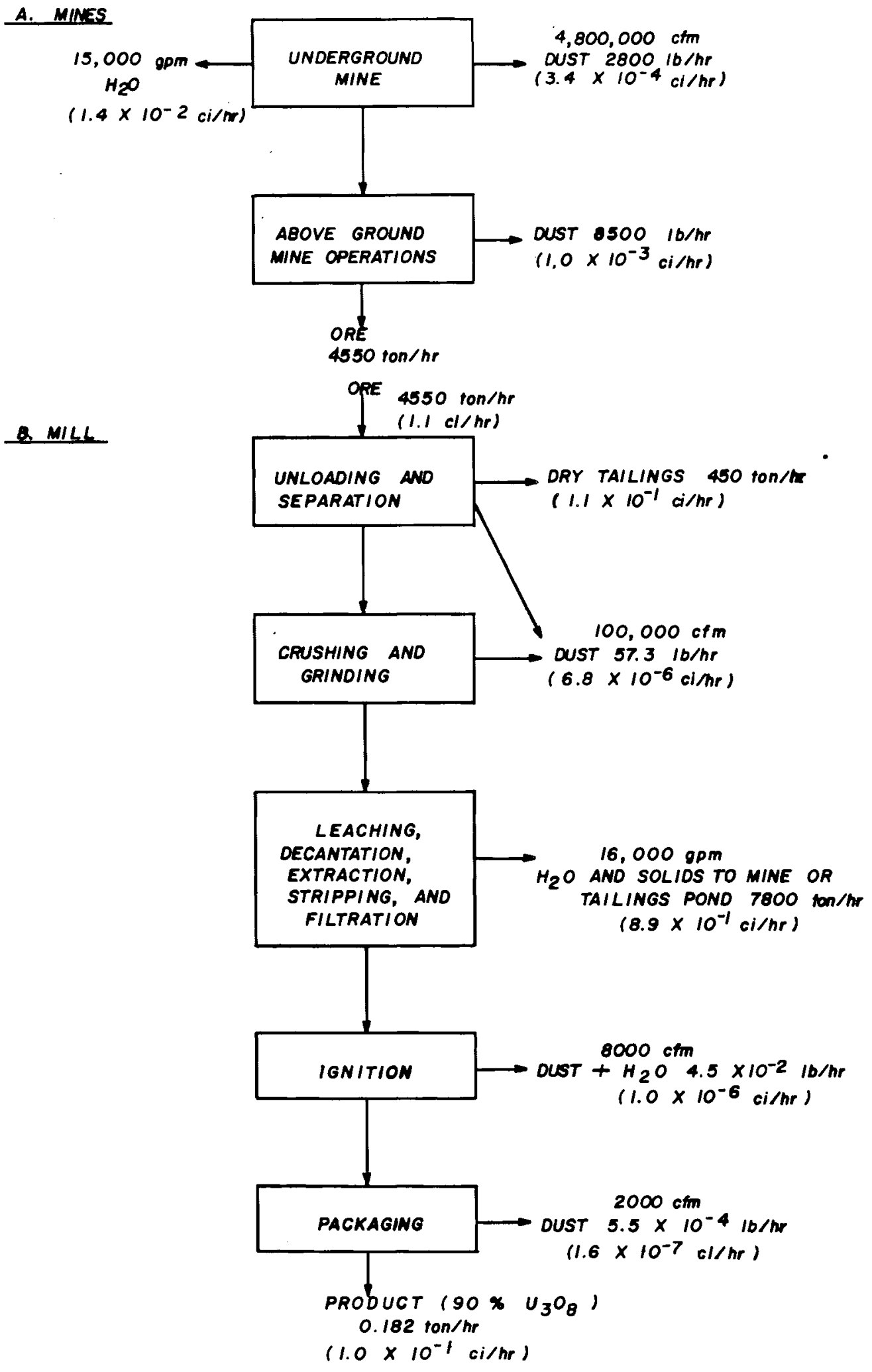

FIGURE 3.2. Chattanooga Shale Mine and Mill Generated Wastes 
The uranium-bearing solution is separated from the waste solids in a series of countercurrent decantation tanks. A 0.05 molar solution of 6-benzylamino-3, 9-diethyltridecane (NBA) dissolved in kerosene is used in the solvent extraction circuit to recover the uranium from solution. An aqueous sodium carbonate solution strips the uranium from the organic solvent. The uranium-bearing sodium carbonate solution is heated and treated with ammonia to precipitate ammonium diuranate. The precipitate is filtered and calcined to form $U_{3} 0_{8}$

The packaged product of $90 \% U_{3} \mathrm{O}_{8}$ is produced at a rate of $364 \mathrm{lb} / \mathrm{hr}$. The $\mathrm{mi} 11$ operates $22 \mathrm{hr} /$ day, 350 days $/ \mathrm{yr}$. In addition to the $U_{3} 0_{8}$ produced, 49,900 bbl/day of synthetic crude oil day are refined. Also vanadium, molybdenum, cobalt, nickel, and thorium may be recovered.

\subsubsection{Milling Generated Wastes and Controls}

There are two main dust streams, two liquid waste streams and one solid waste stream from Chattanooga shale mill operations. The detailed calculations of the waste streams and their levels of radioactivity are shown in Appendix $C$ and summarized in Figure 3.2 .

Airborne wastes are released as the ore from the mine is unloaded, separated according to grade, crushed, and ground. Dust from these operations is released at a rate of $57 \mathrm{lb} / \mathrm{hr}$ and has a radioactive release of $7 \times 10^{-6} \mathrm{Ci} / \mathrm{hr}$. The percentage of $\mathrm{U}_{3} \mathrm{O}_{8}$ in the dust was assumed to be the same as in the ore being crushed $(0.0065 \%)$. Dust is also released from the ignition and packaging operations. The amount released is $4.5 \times 10^{-2} \mathrm{lb} / \mathrm{hr}$, most of which is water from the ignition process. The radioactivity release rate is $1.0 \times 10^{-6} \mathrm{Ci} / \mathrm{hr}$.

The airborne waste streams are controlled by several methods at varying costs. A system of fans and hoods collects dust from the unloading, separating, crushing, and grinding areas and transfer it to two 50,000-cfm cyclone dust collectors. The capital cost for this system is $\$ 70,000$ and the annual cost is $\$ 53,000$. The mill ignition and packaging dust streams are handled separately. The ignition dust stream, because of the water in the stream, is collected by an 8,000-cfm wet impingement scrubber. The capital cost of this 
system is $\$ 18,000$ and the annual cost $\$ 10,000$. The packaging dust, because of its radioactivity level per unit weight, must be closely controlled. A 2,000-cfm baghouse filter system, with a capital cost of $\$ 13,000$ and an annual cost of $\$ 6,000$, is used to control the dust. All of the dust collected in the above systems will be returned to the mill processing stream.

The unloading and separating processes generate 450 tons/hr of dry tailings that require disposal. The radioactivity level of this stream is $1.1 \times$ $10^{-1} \mathrm{Ci} / \mathrm{hr}$. To handle this large stream a belt conveyor system $3 \mathrm{miles}$ long is run from the mill to a landfill site. At the landfill a swing boom stacker distributes the tailings and a bulldozer levels and compacts them. During dry periods of the year the pile will need to be kept wet using sprinklers to prevent offsite release of dust. When the mill is decommissioned the solids pile will cover 320 acres to a depth of $\approx 100 \mathrm{ft}$. (a) A $6 \mathrm{ft}$ earth cover with vegetation will be placed over the pile after the mill ceases operations. The $6 \mathrm{ft}$ earth cover was used for the baseline technology at all of the mills. The capital cost of solids disposal, including the final covering, is $\$ 11,300,000$ with an annual cost of $\$ 3,900,000$.

There are two liquid streams that flow to a tailings pond as shown in Appendix $C$. The largest stream is from the leaching and decantation processes and is $50 \%$ solids. Even the final product has less radioactivity than this waste stream because most of the daughter products are impounded in the pond. The waste stream has a radioactive release rate of $8.9 \times 10^{-1} \mathrm{Ci} / \mathrm{hr}$ at a flow rate of $\simeq 15,700 \mathrm{gpm}$.

In the early years of the mine and mill operations the tailings will be impounded in a 925-acre clay core dam and tailings pond to an average depth of $75 \mathrm{ft}$. This pond will contain a water recycle system so that most of the water is returned to the mill. Even with a clay core dam some seepage ( 0 to 15\%) may take place. In later years the tailings are assumed to be pumped to

\footnotetext{
(a) Volume $=\left(10,000 \frac{\text { ton }}{\text { day }}\right)\left(2000 \frac{\mathrm{lb}}{\text { ton }}\right)\left(\frac{\mathrm{ft}^{3}}{100 \mathrm{lb}}\right)\left(\frac{\mathrm{acre}-\mathrm{ft}}{43,560 \mathrm{ft}^{3}}\right)\left(\frac{350 \text { day }}{\mathrm{yr}}\right)\left(\frac{20 \mathrm{yr}}{\mathrm{mill} 1 \mathrm{ife}}\right)$ $=32,100$ acre-ft
} 
mined out underground areas. Detailed site studies would have to be performed to determine the acceptability of underground disposal. Again, a recycle system will return most of the water to the mill. In both cases lime neutralization of the sludge will take place before disposal to increase the $\mathrm{pH}$ and precipitate out heavy metals and radium. Over the mill's operating lifetime, $\simeq 73 \%$ of these tailings will be returned to the mines and $\simeq 27 \%$ will be disposed of in the tailing pond.

The capital cost of the tailing pond is $\$ 26,700,000$ with an annual cost of $\$ 14,600,000$. The capital cost of the slurry pipeline system from the mill to the mines and a return water pipeline is $\$ 62,800,000$ with an annual cost of $\$ 34,800,000$. In addition to these costs the tailing pond will have to be drained and then covered with $6 \mathrm{ft}$ of earth and vegetation. The capital cost of this cover is $\$ 8,300,000$ with an annual sinking fund cost of $\$ 80,000$. Similarly, the mines will have to be sealed after production at the mill ceases. The cost of sealing the mine will be $\$ 2,000,000$ with an annual sinking fund of $\$ 20,000$. The pond beach dust will also have to be kept wet, using conventional sprayers mounted on trucks, so as to minimize offsite release of dust. The capital cost of controlling the pond beach dust is $\$ 95,000$ and the annual cost is $\$ 170,000$.

Table 3.4 contains a complete cost breakdwn for the above waste control systems. The capital cost of mill waste control systems is $\$ 111,300,000$ and the annual cost is $\$ 53,600,000$. The cost of disposing of the mill tailings, excluding the cost of beach dust control, covering the tails pond, and sealing the mines, is $80 \%$ of the total environmental control capital costs at the Chattanooga mill and $92 \%$ of the total annual costs.

\subsection{REFERENCES}

1. Brown, A. 1956. Uranium in the Chattanooga Shale in Eastern Tennessee, U.S.G.S. prof. paper 300, Washington, D.C.

2. Brown, A. 1962. Preliminary Report on the Economic Potential of the Chattanooga Shale, U.S.G.S. open-file report 75-135, Washington, D.C. 
3. Hickman, R. C. and V. J. Lynch. 1967. Chattanooga Shale Investigations, U.S. Bureau of Mines, R. I. 6932, Washington, D.C.

4. Stockdale, P. B. and H. J. Klepser. 1959. The Chattanooga Shale of Tennessee as a Source of Uranium, University of Tennessee. ORO 205. Chattanooga,. Tennessee.

5. Swanson, V. E. 1960. Geology and Geochemistry of Uranium in Marine Black Shales, U.S.G.S prof. paper 356-C, Washington, D.C.

6. U.S. Department of Energy. 1979. "Engineering Assessment and Feasibility Study of Chattanooga Shale as a Future Source of Uranium", Mountain States Research and Development and PRC Toups Corporation, Grand Junction Colorado. GJBX-4.

7. Mutschler, P. H. et al. 1976. Uranium from the Chattanooga Shale, Some Problems Involved in Development, U.S. Bureau of Mines I.C. 8700, Washington, D.C. 


\subsection{IGNEOUS INTRUSIVES}

Although a majority of proved uranium reserves in the U.S. are associated with sedimentary deposits, igneous rock should not be overlooked as a source of uranium. Recent studies have identified several igneous environments that contain uranium in concentrations that range between 10 to $20 \mathrm{ppm}$. While these concentrations are still low when compared to sandstone deposits with average $\mathrm{U}_{3} \mathrm{O}_{8}$ concentrations around $1000 \mathrm{ppm}$, the size of the igneous deposits represents vast quantities of uranium.

Uranium is a lithophile element with an average crustal abundance of approximately $1.8 \mathrm{ppm}$. Because of its large ionic size, uranium tends to remain in late volatile stages of a magma during fractional crystallization, thus enriching the youngest rocks of an intrusive. Typically this stoichiometric discrimination alone will not produce uranium concentrations greater than about 10 to $20 \mathrm{ppm}$. However, additional geologic processes such as metasomatism and hydrothermal dissolution and redeposition can further concentrate the uranium. Although igneous rock environments currently cannot compete with domestic sandstone deposits as a source of uranium, future market conditions may make them an economically viable alternative.

Igneous intrusives include a myriad of rock types and depositional environments, not all of which may be favorable to uranium concentration. Current studies are attempting to identify and classify those intrusive rock forming regimes with the greatest uranium potential. $(1,2,3,4,5)$ A recent compilation lists major igneous rock formations of the world that contain greater than 10 ppm uranium. (1) The majority of these formations can be included in the 5 following categories:

- granites and alkali granites

- rhyolites

- peralkaline nepheline syenite

- alkaline volcanic rock

- carbonatites.

Alkaline volcanic rock, and generally rhyolites, are extrusive and will be considered as potential uranium resources in another section of this report. 
At least two large deposits of massive carbonatite do occur in the U.S. However, in both cases uranium is too low-grade to be recovered as anything but a by-product of rare earths. One of the deposits, at Mountain Pass, California, is currently extracting rare earths without including a uranium or thorium recovery cycle.

More important domestically are alkaline and peralkaline granitic rock families. Bokan Mountain, in southern Alaska, is often referred to as the domestic type area for peralkaline granite as a uranium source. In fact, the deposit has been mined as a primary source of uranium three different times since the 1950s. Although the ore at Bokan Mountain was in high-grade veins (up to $1 \% U_{3} \mathrm{O}_{8}$ ), it is unique in that it is the only domestic uranium mine with a granitic host rock. While tonnages were small compared to sandstone mines, the significant aspect is that granitic ore was mined and milled economically. Assuming lower-grade granitic environments may someday become viable, they should be included in a study of new sources of uranium.

Some high-grade ore as well as lower-grade halos still occur in the Bokan Mountain area. Because of its past mining history, the area would probably be one of the first granitic environments to be exploited. For this reason the environmental control technologies of Bokan Mountain will be assessed. It is hoped this pragmatic approach will provide usable information on extractive processes that would otherwise be purely conceptual.

\subsection{BOKAN MOUNTAIN}

\subsubsection{Geography and Demography}

Bokan Mountain granite covers an area of about 70 square miles on the southern tip of Prince of Wales Island in southeast Alaska, as shown in Figure 4.1. The Ross-Adams Mine, the initial producing area, is southeast of Bokan Mountain and about two miles northwest of the west arm of Kendrick Bay which was used as an ore shipping point. The area is accessible by floatplane or boat, both of which can be chartered in Ketchikan 40 miles to the northeast. An unpaved haulage road links the mine with Kendrick Bay. Currently the only inhabitants are seasonal; no permanent settlements exist in or near the mineralized area. 


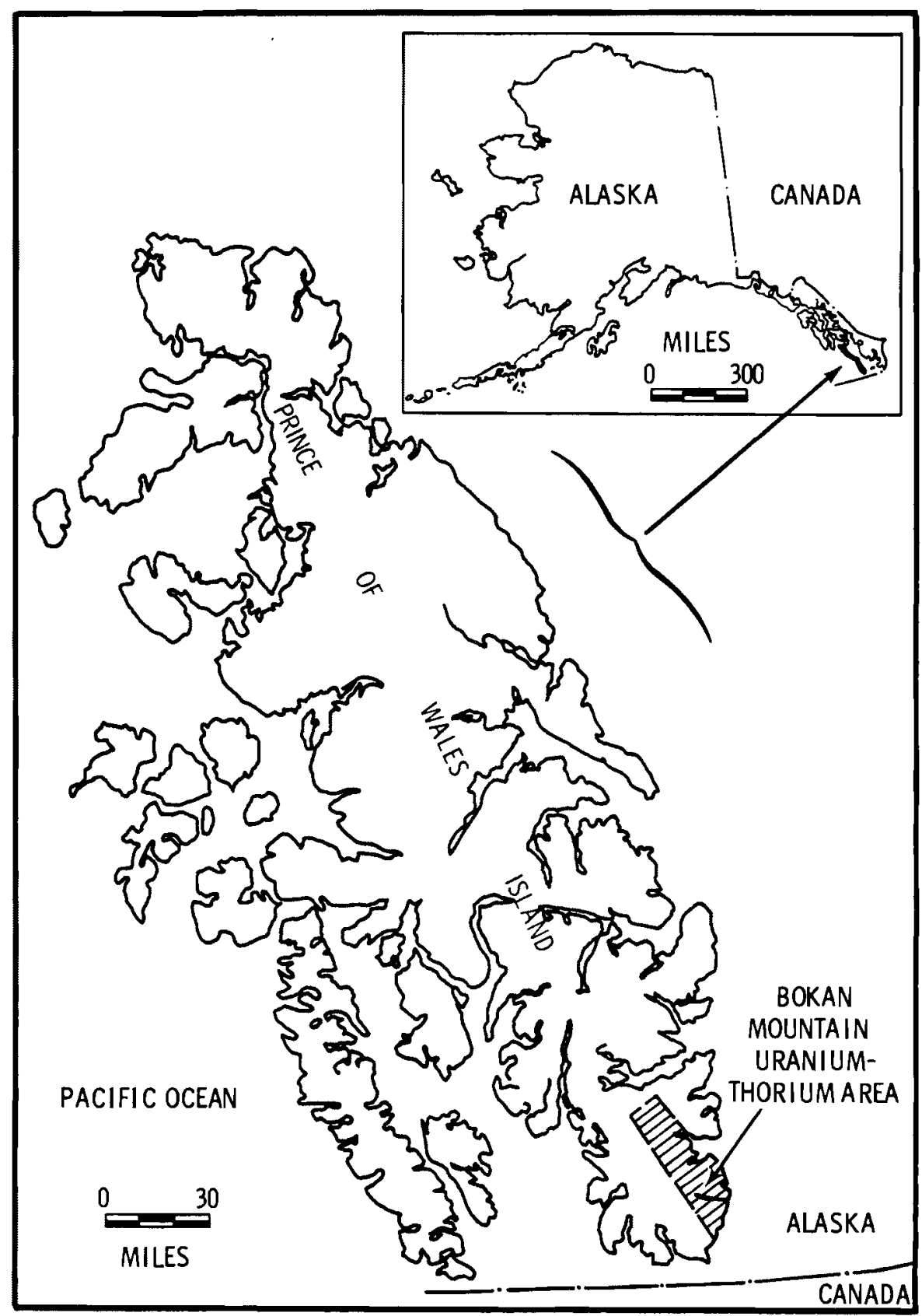

FIGURE 4.1. Bokan Mountain Area 


\subsubsection{Topography}

The Bokan Mountain area is typical of much of southeastern Alaska. Topography is characterized by low hills less than 3,000 ft in elevation. Bokan Mountain itself is slightly over 2,500 ft while the Ross-Adams Mine workings are $950 \mathrm{ft}$ above sea level. There is a general lack of soil with much of the terrain being rocky or covered by glacial till. Steep rocky cliffs border the coastline.

\subsubsection{Meteorology}

Because of its proximity to coastal currents and weather systems, the Bokan Mountain area has a moist and somewhat temperate climate. Total precipitation is over $150 \mathrm{in./yr}$ with approximately $30 \mathrm{in.}$ being snowfall. The mean annual temperature is approximately $45^{\circ} \mathrm{F}$ with highs in the upper $80 \mathrm{~s}$ and the lows in the low 20s. Ventilation data and data on mixing depths at which pollutants disperse has not been collected on the area due to its remoteness. However, it is known strong winds typically blow from the southeast during frequent storms in the area. Large tidal changes ranging up to $20 \mathrm{ft}$ leave a wide littoral zone around the coastline.

\subsubsection{Ecology}

Prince of Wales Island displays vegetation typical of the Alaskan panhandle. The lower coastal regions are covered with rain forests of Sitka spruce, cedar, and hemlock with swampy patches of muskeg. In addition, a thick undergrowth of devilsclub, salmonberry, and blueberry is present. Higher elevations, such as the sumit of Bokan Mountain, are characterized by bare, rocky slopes. Fauna in the area are also typical of that found throughout southern Alaska.

\subsubsection{Hydrology}

Due to the high annual precipitation, abundant surface water exists in the mineralized area. Numerous streams as well as ponds and lakes occur on the intrusive body. Information on groundwater is lacking. However, because unconsolidated glacial regolith makes a good aquifer, substantial amounts of groundwater are probably present. Also, fracture systems common in granitic 
rocks would serve as conduits for groundwater. Data on the chemical composition of surface or groundwater has not been collected.

\subsubsection{Geology and Mineralization}

Regional geology in the Bokan Mountain area is characterized by three separate rock regimes. A series of metavolcanic and metasedimentary slate, schist, gneiss and amphibolite were intruded by a granitic mass composed of diorite, quartz-diorite, quartz monzonite and granodiorite. A subsequent peralkaline granitic boss intruded the older plutonic and metamorphic rocks approximately 18 million years ago. This later intrusive body contains the ore zones and is the source of uranium. Principal minerals of the granitic boss are listed in Table 4.1.

At least four types of uranium ore have been identified at the Ross-Adams prospect. Specifically, syngenetic primary uranium minerals were emplaced both in the main magmatic body and pegmetitic phase. Also, epigenetic secondary hydrothermal mineralization has taken place along ore body fractures and in the surrounding country rock. The principal ore minerals are uraninite $\left(\mathrm{UO}_{2}\right)$ and uranothorianite $\left[(\mathrm{Th}, \mathrm{U}) \mathrm{O}_{2}\right]$.

At the Ross-Adams Mine site, a rich mineralized body approximately 50 by 50 by $400 \mathrm{ft}$ contained ore that ranged from 0.5 to $3.0 \% U_{3} 0_{8}$ but averaged about $1 \%$. (6) Although the rich ore pods were rather sharply defined, the main intrusive body contains small epigenetic veinlets as well as primary fractional enrichment that range in grade from $0.5 \% U_{3} O_{8}$ down to typical concentra-

TABLE 4.1. Principal Minerals of the Bokan Mountain Intrusive Plug

\begin{tabular}{|c|c|c|}
\hline Mineral & Percent & Composition \\
\hline \multicolumn{3}{|l|}{ Felsic } \\
\hline Microcline & 60 & $\mathrm{KAISi}_{3} \mathrm{O}_{8}$ \\
\hline Quartz & $20+$ & $\mathrm{SiO}_{2}$ \\
\hline \multicolumn{3}{|l|}{ Mafic } \\
\hline $\begin{array}{l}\text { Aegerine } \\
\text { Riebeckite }\end{array}$ & 10 & $\begin{array}{l}\mathrm{NaFe}\left(\mathrm{SiO}_{3}\right) \\
\mathrm{NaFe}^{+3}\left(\mathrm{SiO}_{3}\right)_{2}\end{array}$ \\
\hline
\end{tabular}


tions of enriched granite of just over $10 \mathrm{ppm}$. Past mining has removed much of the rich vein ore near the surface, leaving lower-grade halos.

\subsubsection{Mining}

The Ross-Adams Mine has been exploited in three separate phases. In 1957 about 15,000 tons of $1 \% \mathrm{U}_{3} \mathrm{O}_{8}$ ore were removed from a small surface cut and shipped by barge and rail to the Dawn Milling Plant at Ford, Washington. Between 1961 and 1964 the mine was reopened by underground methods and about 25,000 tons of ore averaging $1 \% U_{3} 0_{8}$ were removed by underhand stoping. This ore was processed at the Texas-Zinc Mill at Mexican Hat, Utah. An extensive exploration drilling program was carried out during the late 1960s by Newmont Mining Corporation who again reopened the mine in 1971 using underground methods.

A main adit at elevation $318 \mathrm{ft}$ was serviced by drawpoints of sublevels at elevations of 440,500,600, and $670 \mathrm{ft}$. Ore was loaded underground into 35-ton trucks and hauled 1-1/2 miles to a stockpile near the beach. All underground trucks and loaders were diesel powered and rubber mounted. (7)

This latest phase of mining at the Ross-Adams prospect lasted less than a year including development work. Officials of the Newmont Company estimate between 500 to 800 tons/day of ore averaging $1 \% U_{3} 0_{8}$ were removed during the production phase. In all, some 55,000 tons of ore were transported by barge and rail to the processing mill at Ford, Washington and blended with ore from the Midnite Mine. Ore dilution in the mine was reported to be around $25 \%$.

Although a majority of the easily recoverable high-grade ore at the RossAdams Mine has been excavated, lower-grade halos and steeply dipping higher grades could still be recovered. It is assumed any additional ore removed from deposits at Bokan Mountain would be excavated using methods similar to those described above.

\subsubsection{Mining Generated Wastes and Controls}

The solid waste from the previous mine at Bokan Mountain necessitated the removal and dumping of $\simeq 35,000$ tons of unmillable rock. (4) Some of this was 
used for roads and port facilities. In the two proposed mines the low-grade wall rock and gangue material can be similarly used due to the low level of radioactivity.

Liquid wastes from the proposed mines are assumed to average $500 \mathrm{gpm}$ since the mines can be classified as intermediate (500 to 2,000 gpm) or dry $(<500 \mathrm{gpm})$ mines. The average $\mathrm{U}_{3} \mathrm{O}_{8}$ concentration in the mine water was assumed to be $1 \mathrm{ppm}$ as in the Chattanooga Shale mine. As previously mentioned, there are a number of subsurface conditions that may influence the flow and concentration levels of the mine water.

To control the mine water and fines, a 2-acre settling pond is required for each mine. The pond will receive a liquid flow of $500 \mathrm{gpm}$ containing $0.25 \mathrm{lb} / \mathrm{hr}$ of $\mathrm{U}_{3} \mathrm{O}_{8}$. The amount of radioactivity entering the pond is $4.6 \times$ $10^{-4} \mathrm{Ci} / \mathrm{hr}$. The capital cost of the pond systems is $\$ 387,000$ while the annual cost is $\$ 135,000$.

Airborne wastes at the Bokan Mountain mines are divided between the $1 / 4$ occurring in the mine and the $3 / 4$ occurring in the aboveground operations. The dust in the mines will be controlled by a 1,600,000-cfm ventilation system for each mine. No control measures will be needed for mine dust because it is sufficiently diluted by this system. Thus, the cost of controlling the mine dust is zero as shown in Table 4.2. The cost of the ventilation systems is included as part of the overall mine cost.

The amount of dust generated from aboveground operations is $4,500 \mathrm{lb} / \mathrm{hr}$ with a radioactive release rate of $2.5 \times 10^{-4} \mathrm{Ci} / \mathrm{hr}$. These airborne wastes are controlled by spraying water onto the areas of heaviest dust emissions, and erecting wind barriers. These control measures have a capital cost of $\$ 225,000$ and an annual cost of $\$ 116,000$. The control costs for the mine wastes are shown in Table 4.2 .

4.1.9 Milling Method $(8,9)$

The Bokan Mountain mill processes $0.003 \% \mathrm{U}_{3} \mathrm{O}_{8}$ ore and produces $84 \% \mathrm{U}_{3} \mathrm{O}_{8}$ powder. The ore is received at the rate of 3,000 tons/hr from the mine and is 
TABLE 4.2. Estimated Waste Control Costs for Bokan Mountain Mine and Mill

\begin{tabular}{|c|c|c|c|}
\hline Generated Wastes & Type of Control & $\begin{array}{l}\text { Capital } \\
\text { Cost }(\$ 1000)\end{array}$ & $\begin{array}{c}\text { Annual } \\
\text { Cost }(\$ 1000) \\
\end{array}$ \\
\hline \multicolumn{4}{|l|}{ Mines } \\
\hline Mine Water & $\begin{array}{l}\text { 2-acre settling pond, } \\
\text { ditches, etc. for each } \\
\text { mine }\end{array}$ & 387 & 135 \\
\hline $\begin{array}{l}\text { Underground Mine } \\
\text { Dust }\end{array}$ & $\begin{array}{l}1,600,000 \mathrm{cfm} \text { ventilation } \\
\text { system }\end{array}$ & 0 & 0 \\
\hline $\begin{array}{l}\text { Aboveground Mine } \\
\text { Dust }\end{array}$ & $\begin{array}{l}\text { Spray equipment and wind } \\
\text { barriers }\end{array}$ & 225 & 116 \\
\hline \multicolumn{4}{|l|}{ Mill } \\
\hline $\begin{array}{l}\text { Dust from Unloading, } \\
\text { Crushing and Grind- } \\
\text { ing }\end{array}$ & $\begin{array}{l}\text { Four } 50,000-c f m \text { cyclone } \\
\text { dust collector systems }\end{array}$ & 139 & 106 \\
\hline Drying Dust & $\begin{array}{l}6,000-\mathrm{cfm} \text { wet impingement } \\
\text { scrubber system }\end{array}$ & 14 & 8 \\
\hline Packaging Dust & $\begin{array}{l}2,000-c f m \text { baghouse filter } \\
\text { system }\end{array}$ & 13 & 6 \\
\hline Liquid Wastes & $\begin{array}{l}\text { 2,000-acre tailings pond, } \\
\text { clay core dam, and recycle } \\
\text { system }\end{array}$ & 43,500 & 22,300 \\
\hline $\begin{array}{l}\text { Tailings Pond Radio- } \\
\text { activity }\end{array}$ & $\begin{array}{l}6-\mathrm{ft} \text { earth cover and } \\
\text { vegetation ( } 2000 \text { acres) }\end{array}$ & $\underline{23,000}$ & 220 \\
\hline Total Costs & & 67,300 & 22,900 \\
\hline \multicolumn{4}{|c|}{$\begin{array}{l}\text { unloaded and stored at the mill site. The mill is assumed to operate } 22 \\
\mathrm{hr} / \text { day, } 350 \text { days/yr. The basic process steps are shown in Figure } 4.2 \text { and } \\
\text { described in detail below. }\end{array}$} \\
\hline \multicolumn{4}{|c|}{$\begin{array}{l}\text { The crushing operation is not unique and involves sampling of the ore to } \\
\text { determine ore grade and impurities along with crushing the ore to }<3 / 4 \mathrm{in} \text {. } \\
\text { The crushed ore is then conveyed to one of five } 350 \text {-ton capacity mill bins. }\end{array}$} \\
\hline
\end{tabular}


A. MINES

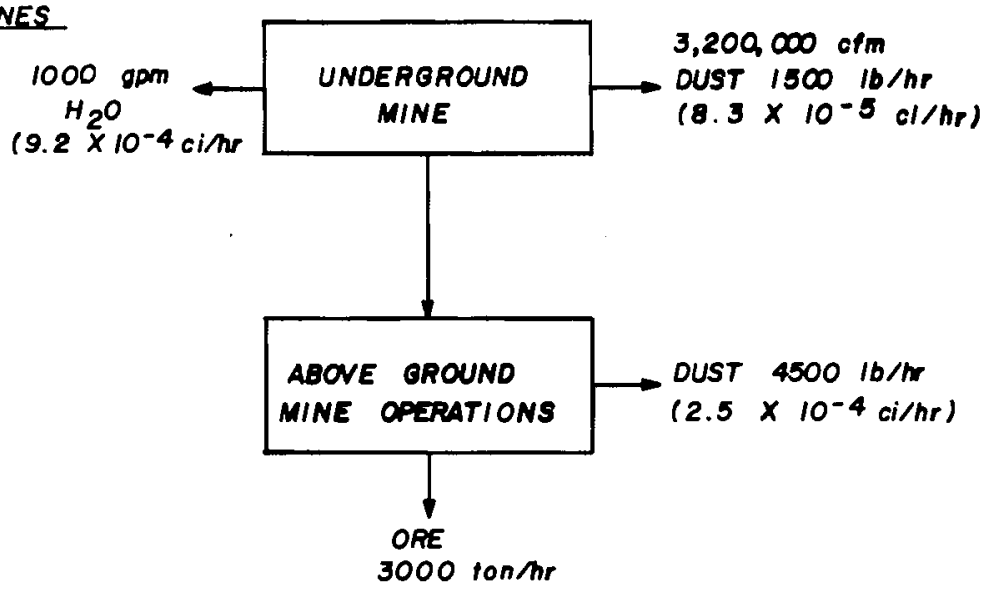

B. MILh

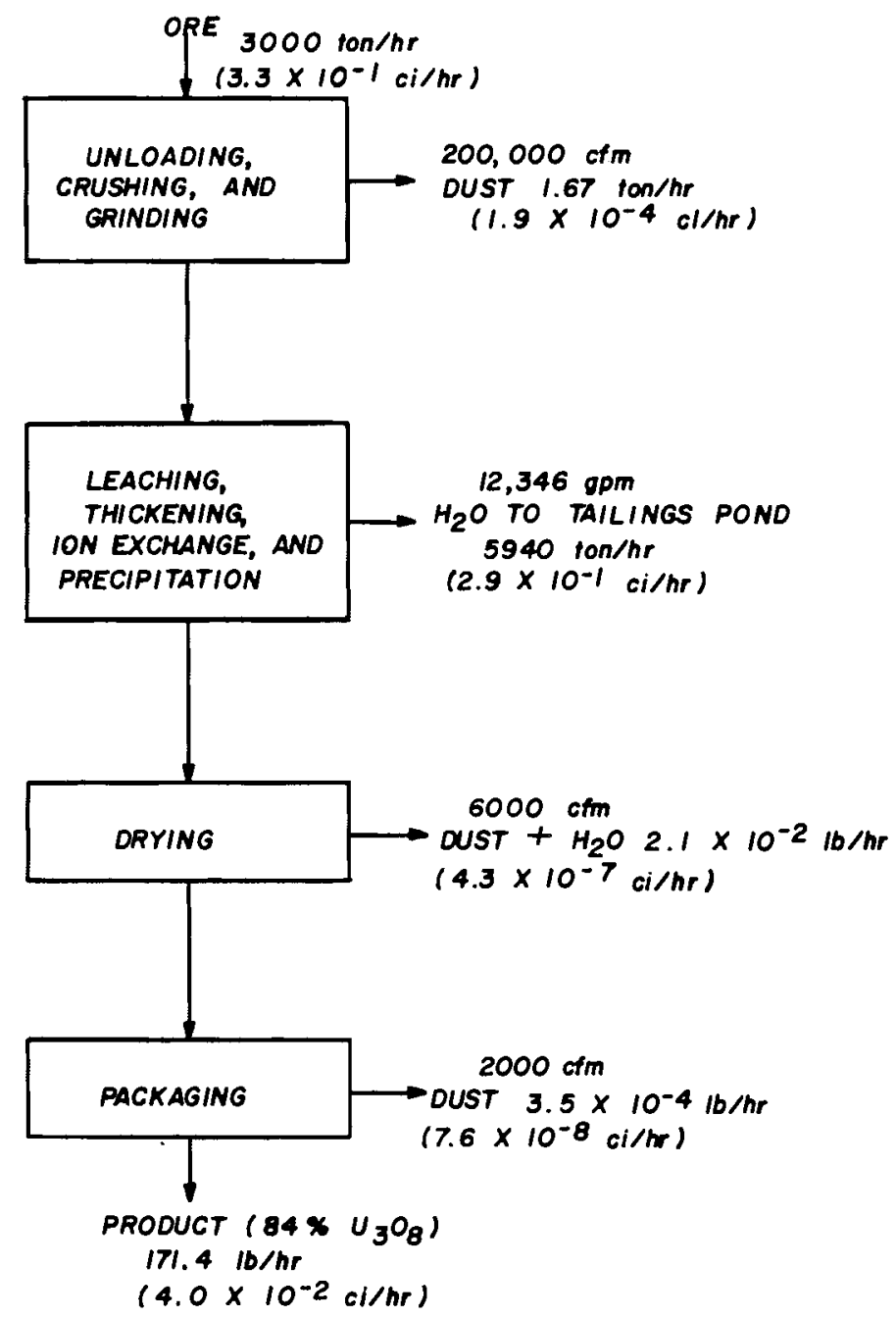

FIGURE 4.2. Bokan Mountain Mine and Mill Generated Wastes 
The ore is ground by a screen head ball mill and conveyed to a classifier where 2,280 tons/hr of water are added. The classifier overflow is pumped to a $10-i n$. cyclone where a $50 \%$ solids cyclone overflow is produced.

The cyclone overflow is pumped to the leach circuit containing seven agitators. At the first agitator acid is added so that the free acid content is $5 \mathrm{~g} / 1$. The amount of uranium dissolved in the primary leach tanks is 30 to $40 \%$. After leaving the primary leach tanks the leached pulp is added to the first counter current decantation (CCD) thickener. The overflow from this CCD is clarified before being pumped to the ion exchange unit (IX) columns. The underflow from the CCD thickener is sent to the secondary leach circuit. This leach circuit adjusts the free acid content to $15 \mathrm{~g} / 1$. The solution is then pumped to a series of three CCD thickeners in an effort to extract any uranium in the solution. The overflow from the second thickener is sent to the primary leach circuit while the underflow from the last thickener is sent to the tailings pond.

The clarified uranium-bearing solution is passed through a bed of anion exchange resins that are contained in a series of vertical columns. In this loading cycle three out of four columns are in use at all times. The lead or top column is removed from the cycle and washed with water to remove the uranium containing solution. The leached column is then backwashed before eluate is added. One column is undergoing elution while the rest are in the loading and/or backwashing cycle. The eluate is ammonium nitrate solution and redissolves the uranium from the resin beads. The column is then regenerated with acid and is returned to the loading cycle. The concentrated eluate is pumped to a series of leach tanks (Pachuca tanks) where iron and sulfates are precipitated out by lime and ammonia gas. After filtration by rotary drum filters, the filtrate is treated with ammonia gas which precipitates uranium as ammonium diuranate in a near-colloidal state. This uranium-enriched solution is thickened in a series of two CCD thickeners and again filtered on a rotary drum filer equipped with a roll discharge.

The filtercake is $\simeq 50 \%$ solids and is sent through an extruder where it forms 3/16-in. pellets. These pellets are passed through a steam drying chamber heated at temperatures of 280 to $290^{\circ} \mathrm{F}$. The pellets are then forced 
through a 1/4-in. screen and the final $84 \% \mathrm{U}_{3} \mathrm{O}_{8}$ concentration is packaged in 55-gal drums for delivery to customers.

\subsubsection{Milling Generated Wastes and Controls}

In the Bokan Mountain mill there are two main dust streams and two liquid waste streams sent to a tailings pond. The detailed calculations of these streams and their levels are shown in Appendix $C$ and summarized in Figure 4.2.

The dust from the unloading, crushing, and grinding circuit is assumed to have the same percentage of $\mathrm{U}_{3} \mathrm{O}_{8}$ as does the entering ore. This dust is emitted at a rate of 1.67 tons/hr with a radioactive release rate of $1.9 \mathrm{x}$ $10^{-4} \mathrm{Ci} / \mathrm{hr}$. The dust emitted from the drying and packaging operations is at a rate of $2.1 \times 10^{-2} \mathrm{lb} / \mathrm{hr}$ of which $\simeq 89 \%$ is water. The radioactive release rate is $5.0 \times 10^{-7} \mathrm{Ci} / \mathrm{hr}$.

To control the unloading, crushing, and grinding dust, four 50,000-cfm cyclone dust collectors will be needed at a capital cost of $\$ 139,000$ and an annual cost of $\$ 106,000$. Dust from the drying and packaging operations is handled separately for each process. The mill drying dust, because it is in a very wet waste stream, is collected in a 6,000-cfm wet impingement scrubber. The capital cost of this scrubber is $\$ 14,000$ and the annual cost is $\$ 8,000$. The mill packaging dust, though of low flow rate, must be completely collected because it is $84 \% U_{3} 0_{8}$. The dust is collected in a 2,000-cfm baghouse filter system with a capital cost of $\$ 13,000$ and an annual cost of $\$ 6,000$. All of the dust collected in the above systems will be returned to the mill processing stream.

Two liquid waste streams flow into the central tailings pond system. Most of the $U_{3} O_{8}(\simeq 83 \%)$ is contained in the 4,920 tons/hr leaching and thickening waste stream. The total radioactivity entering the pond system is $2.9 \times 10^{-1} \mathrm{Ci} / \mathrm{hr}$, which is $\approx 87 \%$ of the radioactivity contained in the ore entering the mill. This is due, in part, to the assumption that most of the uranim daughters are impounded in the tailings pond.

The tailings from the mill are neutralized with lime before disposal in a 2,000-acre tailings pond. This pond has a 260-ft-high clay core dam and a 
water recycle system to return water to the mill. Due to the excessive rainfall in this area, two ponds, in series with a barium chloride treatment system, wlll be needed to treat the overflow from the pond before its discharge to surface waters. The capital cost of the ponding system is $\$ 43,500,000$ and the annual cost is $\$ 22,300,000$. In addition to these costs, at the end of the mill's service life, the pond will be covered with $6 \mathrm{ft}$ of earth and vegetation. The capital cost of this cover is $\$ 23,000,000$ and the annual cost of the sinking fund to provide for it is $\$ 220,000$.

The total capital cost for environmental control at the Bokan Mountain mill is $\$ 66,700,000$ and the annual cost is $\$ 22,600,000$, as shown in Table 4.2. The mill tailings pond system, including the tailings pond cover, accounts for $>99 \%$ of the capital costs and $\approx 99 \%$ of the annual costs.

\subsection{REFERENCES}

1. Nishimore, R. K. et al. 1977. Uranium Deposits in Granitic Rocks, (GJBX-13(77), University of North Carolina, Chapel Hill North Carolina.

2. Murphy, M. H. 1978. Uranium in Alkaline Rocks, LBL-7029, Lawrence Berkeley Laboratories, Berkeley, California.

3. Matthews, G. W. 1977. A Classification of Uranium Deposits in and Related to Plutonic Igneous Rocks; Bendix Field Engineering Corporation, NURE Geology Uranium Symposium, Grand Junction, Colorado.

4. Armstrong, F. C. 1974. Uranium Resources of the Future "Porphyry" Uranium Deposits, in Formation of Uranium Ore Deposits, International Atomic Energy Agency.

5. DeVoto, R. H. 1978. Uranium Geology and Exploration, Colorado School of Mines, Golden, Colorado.

6. Mackeve 11, E. M. 1963. Geology and Ore Deposits of the Bokan Mountain Uranium-Thorium Area Southeastern Alaska, U.S.G.S. BuTT, 1154, washington, D.C.

7. Stephens, F. H. 1971. "The Kendrick Bay Project," Western Miner, pp. $151-158$.

8. Dayton, S. 1978. "Dawn: A First-Generation Plant with Column Ion Exchange," Engineering and Mining Journal, pp. 118-121.

9. Hargrave, D. 1958. "Dawn's Uranium Plant Features Acid Extraction and Column IX." Mining Wor ld, pp. 34-41. 


\subsection{VOLCANIC DEPOSITS}

Recent discoveries at Pena Blanca, Mexico have done much to stimulate new interest in volcanic deposits as a source of uranium. At least 105 radioactive anomalies have been discovered in these Mexican volcanic environments with ore grades averaging $0.2 \% \mathrm{U}_{3} \mathrm{O}_{8}$. Drilling programs have established 4,500

tons of proved $\mathrm{U}_{3} \mathrm{O}_{8}$ with potential for up to 50,000 tons. (1) Although complete data is lacking on domestic uranium contained in volcanic sediments, the Department of Energy has recognized the potential of such deposits and is currently conducting field studies to better define the resource base. (2)

Numerous local uranium anomalies in volcanic deposits of the western Great Basin were discovered during the 1950s. (3) Although mining was carried out at several locations, a combination of decreasing demand and the discovery of large roll-type sandstone deposits resulted in declining interest in volcanics. As prices increase and sandstone deposits become more difficult to discover and exploit, volcanic environments may well become significant sources of nuclear fuel.

Several geologic phenomena associated with volcanic deposits lend themselves to concentrating uranium:

- primary concentration of ejecta by fractional magmatic separation

- plumbing systems caused by cauldron collapse or resurgent activity

- structural and chemical traps at volcanic unconformities

- cauldron basin encatchment for leachable uranium-bearing sediments

- hydrothermal activity resulting from resurgence.

Much volcanic material is enriched in uranium by fractional crystallization before being extruded. In addition, fracture systems resulting from volcanic activity provide plumbing systems through which mineral-bearing solutions can percolate. These mineral solutions can be a result of leaching from above or rising from resurgent activity. Often times a collapsed cauldron will collect uraniferous volcanic lake sediments that are readily leachable. Also, resurgent rhyolite plugs are generally much richer (up to $0.52 \% \mathrm{U}$ ) than primary ejecta and are often associated with hydrothermal fluids. (4) These 
uranium ore concentrating mechanisms are currently being investigated under the NURE Program to determine the potential significance of volcanic environments. (2)

During the activity of the 1950s, numerous uranium anomalies were discovered in volcanic rocks of the Western Great Basin. Several of these deposits were actively mined in Utah and Arizona. In addressing environmental control technologies associated with extracting uranium from volcanic mineral regimes, it was decided to evaluate a previously developed deposit. Typically, licensing requirements are much less burdensome for areas that have past mining histories. Thus, it is highly probable these deposits would be reopened before developing new areas. Clearly, such an assessment would be more relevant than a conceptual design in a virgin area.

Several cauldron systems occur throughout the central Great Basin. Four of the most promising areas are:

- McDermitt Caldera; Oregon-Nevada border

- Fish Creek Caldera; central Nevada

- Thomas Caldera; west central Utah

- Mount Belknap Caldera; central Utah.

Volcanic environments of the Thomas Caldera have been mineralized in uranium as well as beryllium and fluorine. Between 1953 and 1962 uranium was produced from volcanic sediments at the Yellow Chief Mine on the west side of the Thomas Caldera. Beryllium is currently being recovered from several surface mines at nearby Spor Mountain. Because of the area's mineralization and mining history, it was selected as a type area to address environmental control technologies associated with recovering uranium from volcanics.

\subsection{THE THOMAS CALDERA}

\subsubsection{Geography and Demography}

Mineralized volcanic deposits of the Thomas Caldera are located on the west side of the Thomas Mountain Range in west central Utah as shown in Figure 5.1. The nearest populated area is the community of Delta which lies 45 miles to the southwest and has a population of approximately 2,000. 


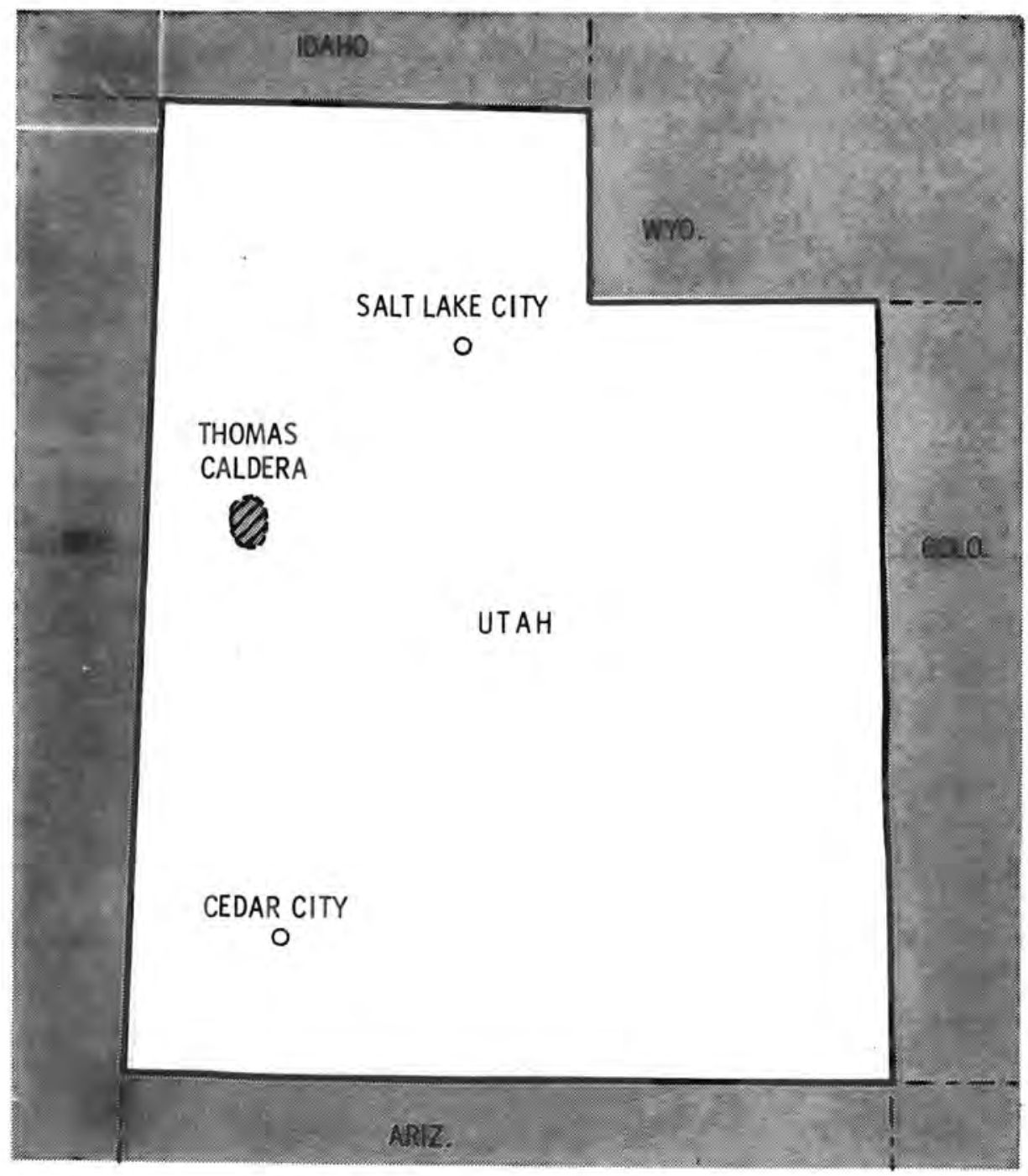

FIGURE 5.1. Thomas Caldera Area

Unincorporated communities of Callao and Trout Creek are located approximately 30 miles to the west of the deposits. Both of these communities have sparse rural populations.

\subsubsection{Geomorphology}

The Thomas Range lies on the western margin of the Great Salt Lake Desert and displays typical basin and range topography. That is, featureless, arid plains are occasionally broken by low, barren hills. More than $80 \%$ of the 
total surface area has less than $8 \%$ slope grade whille local elevation difference is less than $300 \mathrm{ft}$. Soils consist of volcanic aluvium and Lake Bonneville sediments, low in organic matter.

\subsubsection{Meteorology}

An arid, semi-desert environment characterizes the climate of the Thomas Caldera. Average precipitation is less than $10 \mathrm{in./yr}$. Because of the arid conditions, runoff averages less than $2 \mathrm{in./yr}$. Average annual pan evaporation ranges from 48 to $64 \mathrm{in.}$. Annual temperatures average in the high $40 \mathrm{~s}$ with extremes ranging from minus 20 to over $200^{\circ} \mathrm{F}$.

Winds in the area are moderate throughout the year ranging from 5 to $10 \mathrm{mph}$ and tend to come from the southeast.

The average afternoon mixing depth at which pollutants disperse above the Thomas Caldera ranges from 2.0 to $2.5 \mathrm{~km}$. Average wind speed through this mixing depth ranges from 6 to $8 \mathrm{~m}^{2} / \mathrm{sec}$. Ventilation data for the area are given in Table 5.1 .

TABLE 5.1. Afternoon Ventilation Data for the Thomas Range

\begin{tabular}{lcc} 
Season & & $\begin{array}{c}\text { Afternoon } \\
\text { Ventilation }\end{array}$ \\
\cline { 3 - 3 } Spring & & $12-18$ \\
Summer & & Over 24 \\
Fall & $12-18$ \\
Winter & $6-12$
\end{tabular}

\subsubsection{Ecology}

Thomas Caldera lies on the eastern margin of the Great Basin and is characterized by a Great Basin biome. The chief plants present are deciduous microphyll shrubs, sagebrush, saltbrush, greasewood and shadscale. Principal animals of the area are jack rabbits, kangaroo rats, kangaroo mice, pocket mice and antelope ground squirrels. 
Aquatic life does not occur in the area surrounding the Thomas Caldera because of the lack of surface water.

\subsubsection{Hydrology}

Because of the arid climate and lack of surface runoff, no perennial surface water exists in the Thomas Range. Unconsolidated aquifers of alluvial sediments do, however, contain groundwater in the surrounding area. Recharge to the aquifers is from precipitation and runoff from nearby mountains.

\subsubsection{Geology and Mineralization}

Geology in the Thomas Mountain Range is characterized by paleozoic metasediments overlain by folded volcanic sediments of tertiary age. Regional block faulting has resulted from Caldera collapse. Local stratigraphy at the Yellow Chief mine is a sedimentary sequence of reworked volcanic tuffs, sandstone, and conglomerate, in contact with crystalline volcanic tuff. Ore lenses are located within a host of massive, poorly sorted, conglomeratic, tuffaceous sandstone. General composition of the host rock sandstone component is listed in Table 5.2 The conglomeratic material in the host rock is mainly composed of rounded volcanic rocks ranging in size from gravel boulders over $4 \mathrm{ft}$ in di ameter .

TABLE 5.2. Sandstone Host Rock Composition, Yellow Chief Mine(5)

\begin{tabular}{lr}
\multicolumn{1}{c}{ Constituent } & Percent Comp \\
Cement & 36 \\
(glassy, micaceous, clay) & 26 \\
Quartz & 18 \\
Sanidine & 7 \\
Plagioclase & 5 \\
Mafic Minerals & 7 \\
Rock Fragments & 1 \\
Heavy Minerals & 100 \\
$\quad$ Total &
\end{tabular}


Ore occurs as numerous epigenetic lenticular masses ranging up to $300 \mathrm{ft}$ long and $20 \mathrm{ft}$ thick. These mineralized bodies occur throughout the full vertical extent of the host unit from near surface down to about $120 \mathrm{ft}$. Principal uranium mineralization is beta-uranophane $\mathrm{Ca}\left(\mathrm{UO}_{2}\right)_{2}\left(\mathrm{SiO}_{3}\right)_{2}(\mathrm{OH})_{2} \mathrm{HH}_{2} \mathrm{O}$ and is thought to be an alteration product of coffinite $U\left(\mathrm{SiO}_{4}\right)_{1-x}(\mathrm{OH})_{4 x}$ or uraninite $\left(\mathrm{UO}_{2}\right)$. Individual lenses contain from a few tens up to several thousand tons of ore with grades ranging up to $0.23 \% \mathrm{U}_{3} \mathrm{O}_{8}$.

\subsubsection{Mining}

Mining at the Yellow Chief prospect had been carried out in several phases. Small tonnages were extracted in the initial production by surface excavations with a dozer and front end loader. The first significant production was by underground room-and-pillar mining with drifts and crosscuts totaling over 1,000 ft. Most recent production commenced in 1959 with open-pit operations that consumed the entire underground system and smaller open-cuts.

Overburden and waste were broken by dozer-mounted rippers and removed to nearby dumps. Ore-bearing material was stockpiled by grade and later trucked to the railhead at Delta before being shipped to the Vitro Chemical Company mill in Salt Lake City.

\subsubsection{Mining Generated Wastes and Controls}

The open-pit mine at the Thomas caldera produces 5.5 to $10 \mathrm{yd}^{3}$ of solid waste per ton of ore mined. This figure was obtained from a beryllium mine in the same area operated by the Brush Wellman Company. This solid waste, consisting of gangue and low-grade rock, can be stored onsite as it is of such low radioactivity that there will be no harmful external environmental effects.

The mine water was assumed to contain only $1 \mathrm{ppm}$ of $\mathrm{U}_{3} \mathrm{O}_{8}$, due to the low grade of ore. The mine was assumed to be a dry mine because of the arid environment. Therefore, the flow rate is $250 \mathrm{gpm}$. The total radioactive release rate for the mine water is $2.3 \times 10^{-4} \mathrm{Ci} / \mathrm{hr}$. Since this rate is not very high, a 1-acre settling pond is the only treatment method needed to meet present standards. The water will then be used in the mill as process water. The capital cost for the settling pond, pipes, and pumps is $\$ 83,000$, and the annual cost is $\$ 30,000$. 
About $0.125 \%$ of the ore mined or $7,500 \mathrm{lb} / \mathrm{hr}$ will be released as dust. Due to the open-pit mine design the dust cannot be completely controlled. To keep, the dust levels low, the roads, yards, and storage piles will be wet down by spray equipment and the ore storage piles will be sheltered from the wind. The total capital cost for dust control at the mine is $\$ 225,000$, and the annual cost is $\$ 281,000$. Most of the capital costs (67\%) are for the wind barriers. All of the costs are shown in Table 5.3.

The total capital cost for the mine environmental control methods and equipment at the Thomas Caldera mine is $\$ 308,000$ and the annual cost is $\$ 311,000$.

\subsubsection{Milling Methods $(6,7,8)$}

The Thomas Caldera mill processes $0.003 \%$ of $\mathrm{U}_{3} \mathrm{O}_{8}$ ore and produces $90 \%$ $\mathrm{U}_{3} \mathrm{O}_{8}$ powder. The ore is received at the rate of 3,000 tons/hr from the mine and is unloaded and stored at the mill site. The mill is assumed to operate $22 \mathrm{hr} /$ day, 350 days $/ \mathrm{hr}$. The basic process steps are shown in Figure 5.2 . Each of these steps is described in more detail below.

The primary crushing of the ore to $5 / 8$ mesh size is performed in an impact special breaker. After crushing, a small sample is taken to determine ore chemistry for further processing steps. The rest of the crushed ore is ground in ball mills to $\simeq 25$ mesh after being mixed with water.

Leaching is performed in a series of six 10,000-gal tanks. The slurry from the ball mills enters the bottom of the tank and the overflow from one leach tank is discharged to the next in the series. Sulfuric acid and sodium chlorate are fed to the first tank.

Leached residue and heavy metal sulfides are separated from the $\mathrm{U}_{3} \mathrm{O}_{8}$ bearing liquor in a series of four $70-\mathrm{ft}$ in diameter counter current decantation tanks. The final underflow stream is sent to the tailings pond and the overflow from the first stage, containing about $1.25 \mathrm{~g} / 1 \mathrm{U}_{3}{ }_{0}$, goes to the solvent extraction process.

The pregnant liquor enters the first of four extraction stages. The uranium-rich solvent from the first stage is pumped to the stripping process while the raffinate in the fourth stage is discarded. Each extraction stage 
TABLE 5.3. Estimated Waste Control Costs for Thomas Caldera Mine and Mill

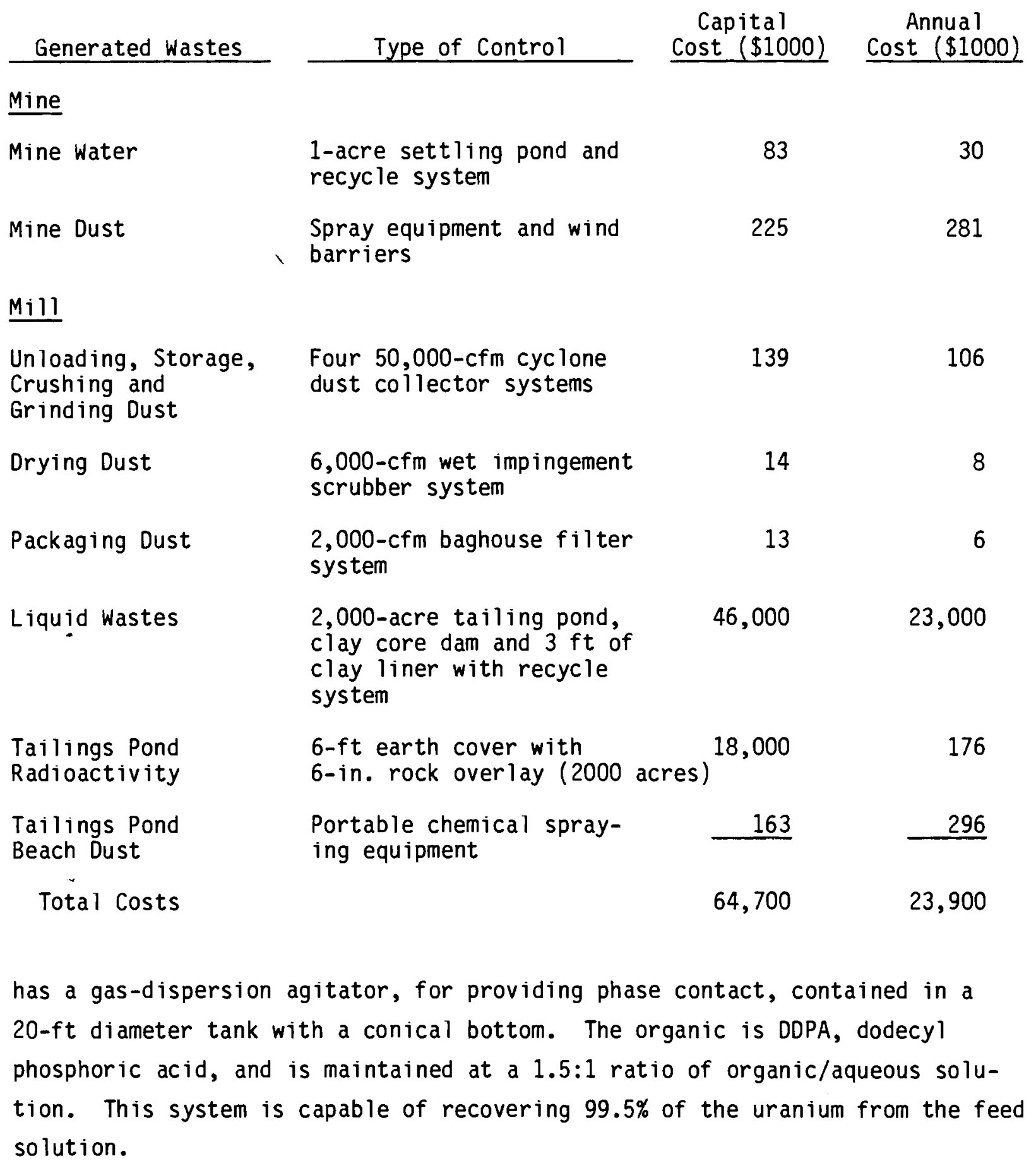


A. MINE

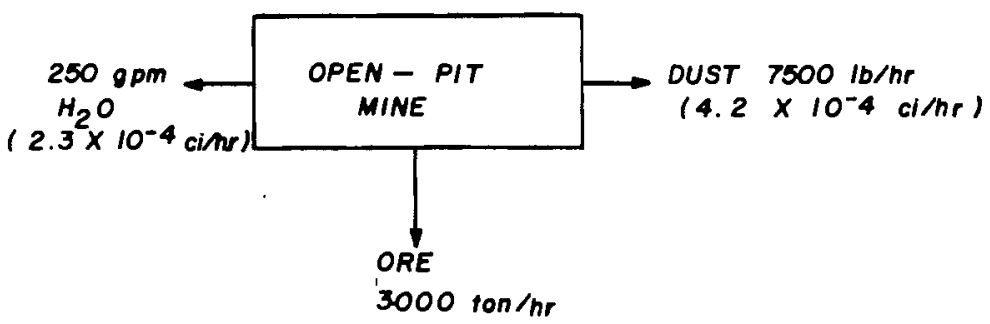

B. $M / L L$

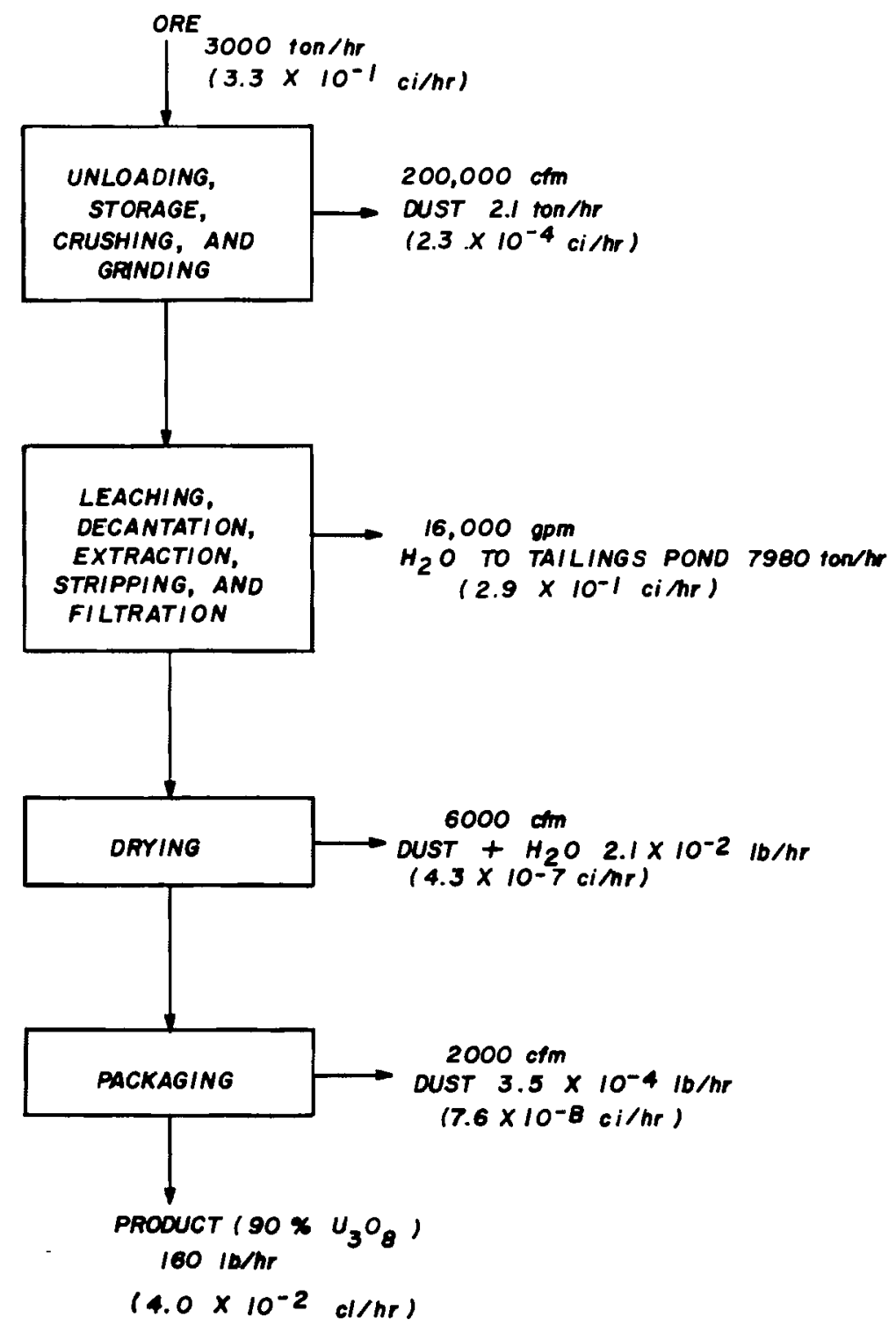

FIGURE 5.2. Thomas Caldera Mine and Mill Generated Wastes 
Solvent from the extraction stage is stripped with a $10 \mathrm{~N} \mathrm{HCl}$ solution in a five stage counter current stripping section. The stripping section was designed to strip the solvent to $0.2 \mathrm{~g} / 1$ of $\mathrm{U}_{3} \mathrm{O}_{8}$ with an organic/aqueous ratio of $8: 1$ to $20: 1$. The richer $20: 1$ ratio reduces the burden on the evaporator to which the uranium-rich hydrochloric acid is sent. The stripped organic (DDPA) is recycled back to the extraction section of the plant.

The evaporator is used to recover as much hydrochloric acid as possible from the uranium-rich solution containing 50 to $100 \mathrm{~g} / 1$ of $\mathrm{U}_{3} \mathrm{O}_{8}$. The evaporator consists of two units or stages for evaporation and a dehydrator and condensor. The bottoms from the second evaporator are sent to the precipitation and filtration section of the plant and have a concentration of $800 \mathrm{~g} / 1$ of $\mathrm{U}_{3} \mathrm{O}_{8}$. Over $90 \%$ of the hydrochloric acid (10N) is recovered and recycled back to the stripping tanks.

In the precipitation and filtration section of the plant the uranyl chloride from the second evaporator is diluted with water, ammonium diuranate is converted to $\mathrm{U}_{3} \mathrm{O}_{8}$, and the chloride level is reduced in a multiple hearth calciner. The final product is packaged in bulk and has a $90 \% \mathrm{U}_{3} \mathrm{O}_{8}$ content.

\subsubsection{Milling Generated Wastes and Controls}

The Thomas Caldera mill operations produce three dust streams and two liquid waste streams requiring treatment. The detailed calculations of these streams and their levels are shown in Appendix $C$ and summarized in Figure 5.2.

The three dust streams all have various emission and radioactive release rates. The unloading and storage operation releases 1.67 tons/hr of dust which is the largest amount in the mill. The $U_{3} 0_{8}$ content is assumed to be the same percentage in the dust as in the entering ore, $0.003 \%$. The radioactive release rate is $1.9 \times 10^{-4} \mathrm{Ci} / \mathrm{hr}$ for this stream. The crushing and grinding dust is very similar to the unloading and storage dust in its physical properties but is released at a much lower rate, $867 \mathrm{lb} / \mathrm{hr}$. The radiactive release rate of this stream is also lower, $4.8 \times 10^{-5} \mathrm{Ci} / \mathrm{hr}$. The drying and packaging dust is emitted at a rate of $2.1 \times 10^{-2} \mathrm{lb} / \mathrm{hr}$ of which $90 \%$ is water. The dust that is emitted is $90 \% \mathrm{U}_{3} \mathrm{O}_{8}$ as is the product. The radioactive release rate of the combined drying and packaging dust streams is $5.1 \mathrm{x}$ $10^{-7} \mathrm{Ci} / \mathrm{hr}$. 
The unloading and storage, and crushing and grinding dust streams are controlled by four 50,000-cfm cyclone dust collectors. The capital cost of this dust control system is $\$ 139,000$ and the annual cost is $\$ 106,000$. The mill drying dust is handled separately from the packaging dust due to the water in the dust stream. The drying dust is collected in a 6,000-cfm wet impingement scrubber that has a capital cost of $\$ 14,000$ and an annual cost of $\$ 8,000$. The packaging dust, though small in volume, must be carefully controlled due to its value. For this reason a 2,000-cfm baghouse filter system is used which has a capital cost of $\$ 13,000$ and an annual cost of $\$ 6,000$. All solids collected in the above systems are recycled back into the main mill processes.

Two liquid waste streams flow into the central tailings pond. The largest and most radioactive stream, from the leaching and decantation processes, flows at a rate of $15,900 \mathrm{gpm}$ and contains $38 \mathrm{lb} / \mathrm{hr}$ of $\mathrm{U}_{3} \mathrm{O}_{8}$. The total amount of radioactivity entering the pond is $2.9 \times 10^{-1} \mathrm{Ci} / \mathrm{hr}$. This is the most radioactive waste stream in the plant due to the assumption that most of the ${ }^{235} \mathrm{U}$ daughters are impounded in the pond.

A 2,000-acre tailings pond with a 260-ft-high clay core dam will be needed to allow for containment of tailings solids generated during the mill's life. The water will be recycled back to the mill for use as process water. In the arid environment the tailings pond will need a clay liner to prevent any seepage from the pond. All tailings will be neutralized with lime before being put into the pond. The capital cost for the tailings pond system, including recycle, is $\$ 46,000,000$ and the annual cost is $\$ 23,000,000$.

To control the beach dust and keep the off-site release of radiation to a minimum, the exposed tailings will be sprayed with chemicals by truck mounted sprayers. The capital cost of this control is $\$ 163,000$ and the annual cost is $\$ 296,000$. As in the other mills, the tailings pond will have a $6-\mathrm{ft}$ earth cover added after mill operations cease. Due to the arid environment, a 6-in. rock covering will be put on the top of the earth instead of vegetation. The capital cost of the cover will be $\$ 18,000,000$ and the sinking fund annual cost will be $\$ 176,000$. 
The total capital cost for the environmental control of waste at the Thomas Caldera mill is $\$ 64,400,000$ and the annual cost is $\$ 23,600,000$, as shown in Table 5.3. The mill tailings pond, not including the costs of beach dust control or the pond cover, is $\simeq 71 \%$ of the capital cost of the mill's control systems and $\simeq 98 \%$ of the annual cost.

\subsection{REFERENCES}

1. Devoto, R. H. 1978. Uranium Geology and Exploration, Colorado School of Mines, Golden, Colorado.

2. Files, J. J. 1978. Uranium in Volcanic Environments in the Great Basin, GJBX-98(78), Grand Junction Office, Grand Junction, Colorado.

3. White, M. B. and P. A. Garland. 1978. Geological and Geochemical Aspects of Uranium Deposits: A Selected, Annotated Bibliography, GJBX-15(78), Grand Junction Office, Grand Junction, Colorado.

4. Rytuba, J. J. 1977, Uranium Content of Tuffaceous Sediments and Opalite Mercury Deposits within the McDermitt Caldera, Oregon-Nevada, G.S.A. Abstract V. 9, No. 4, Falls Church, Virginia.

5. Bowyer, B. 1965. "Yellow Chief Uranium Mine, Juab County, Utah." Guide Book to the Geology of Utah, No. 17, Salt Lake City, Utah.

6. Black, K. L. et al. 1958. "Design and Operation of a Uranium Processing Mill Using Liquid Ion Exchange (Solvent Extraction)," Proceedings of the Second United National International Conference on the Peaceful Uses of Atomic Energy, Vol. 3: Processing of Raw Materials, Geneva, Switzerland.

7. Hutt 1, J. B. 1955. "Vitro's Keys to Successful Uranium Leaching." Engineering and Mining Journal. 156(9):100-104.

8. Tennermann, W. L. 1956. "If You're Planning Uranium Extraction, Take a Look at Today's Flowsheets." Engineering and Mining Journal.

$157(6 a): 122-132$. 


\subsection{PHOSPHATE ROCK}

The occurrence of uranium in phosphate material was first recognized in the early 1900s. Analysis has determined domestic marine phosphate deposits typically contain between 50 to $150 \mathrm{ppm}$ uranium. Current studies estimate $22.5 \times 10^{6}$ short tons of uranium are contained in recoverable U.S. phosphate deposits. (1)

Small amounts of uranium were recovered from phosphoric acid by solvent extraction during the late 1950s and early 1960s. Since that time considerable research has been done to make the recovery process more efficient. As a result, phosphates are proving to be a viable source of uranium.

Domestic phosphate reserves and resources are vast; reported to be in the billions of metric tons. Although there are several types of phosphate deposits, the majority are of marine origin and have consistent concentrations of uranium within the range specified above. All significant domestic phosphate deposits occur in the phosphoria formation of the western U.S. or in southern states along the Atlantic seaboard.

Currently two methods are used to process phosphatic material. In one process, phosphate rock is burned in furnaces to produce elemental phosphorous. Unfortunately, technology has not been developed to recover uranium from this thermal process. The other method digests phosphate rock with sulfuric acid in what is known as the "wet process." Uranium can be recovered by solvent extraction in this wet process.

Approximately $80 \%$ of current U.S. phosphate production is from deposits in Florida and virtually all of this material is reduced by the wet process. Because a large portion of future uranium from phosphates will undoubtedly come from Florida, that area has been selected as a typical region in our environmental assessment. Specifically, a typical phosphate operation in central Florida has been selected to characterize environmental impacts of uranium recovery from phosphate ores. 
Due to the growing interest in phosphates as a source of uranium, the U.S. Department of Energy has recently commissioned a comprehensive study on domestic and world phosphates. (1) Generally, the DOE study identifies phosphate resources and investigates the economic feasibility of recovering uranium. Data presented below on resources and process technology has been abstracted from the DOE study. However, the primary concern here is to address the cost of environmental control technologies associated with the recovery of uranium from phosphates.

\subsection{CENTRAL FLORIDA PHOSPHATE DISTRICT}

\subsubsection{Geography and Demography}

Central Florida phosphate deposits cover an area of about 2,000 square miles in the west central Florida panhandle. Specifically, the deposits occur within Polk, Hillsborough, Hardee, Manatee, DeSoto, and Sarasota Counties. A geographic index map is given in Figure 6.1.

A majority of the population within the central Florida phosphate district lies along the Gulf of Mexico coastal regions. Tampa is the largest population center of the region with about 280,000 people. Gulf Coast communities of Sarasota (pop. 48,000) and Bradenton (pop. 25,000) contain a large percentage of retired people and are located on the western fringe of the mineralized area. The greatest number of mines currently producing phosphate are located in southwestern Polk County, approximately 15 miles from Lakeland, which has a population of approximately 50,000. Some general data on the district's demography is presented in Table 6.1

\subsubsection{Geomorphology}

Landforms in the central Florida phosphate district are typical of the Florida panhandle and Atlantic Seaboard. The terrain is characterized by flat plains with more than $80 \%$ of the area gently sloping with an elevation of $<100 \mathrm{ft}$ above sea level. Because of its low elevation, much of the mineralized area is marsh and swampland covered by standing water or sandy sediments. Soils in the area have amorphous subsurface horizons consisting of organic matter and compounds of aluminum. 


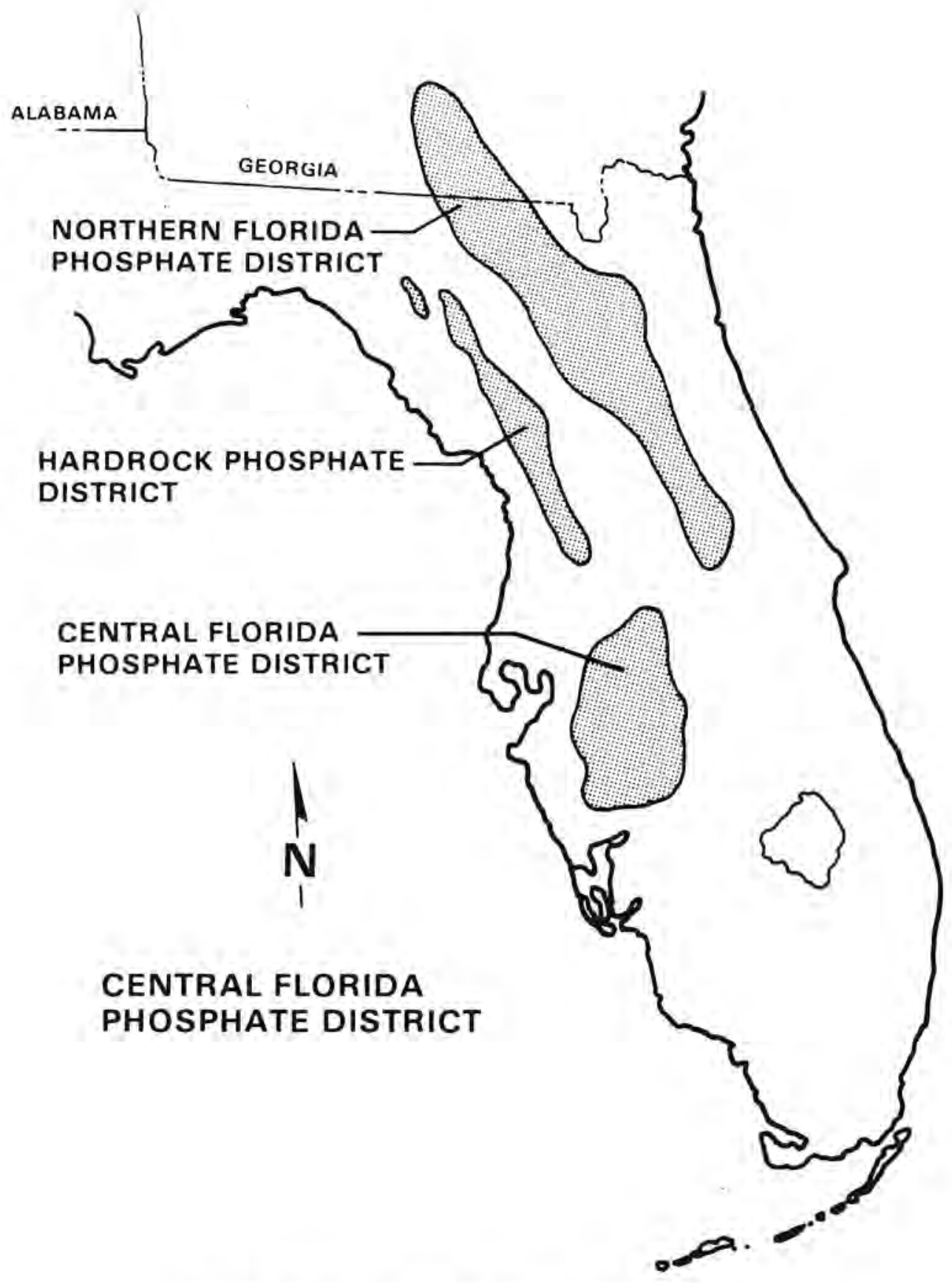

FIGURE 6.1. Florida Phosphate Areas 
TABLE 6.1. Demography of the Central Florida Phosphate District(2)

\begin{tabular}{|c|c|c|c|c|}
\hline County & $\begin{array}{l}\text { Population per } \\
\text { Square Mile }\end{array}$ & $\begin{array}{c}\text { Total } \\
\text { Population } \\
\end{array}$ & $\begin{array}{l}\% \text { Change in } \\
\text { Population } \\
1970-75 \\
\end{array}$ & $\begin{array}{l}\text { \% Population } \\
\text { Over Age } 65\end{array}$ \\
\hline Desoto & 26 & 17,000 & 33 & 15 \\
\hline Hardee & 29 & 1,800 & 20 & 10 \\
\hline Hillsborough & 556 & 578,000 & 20 & 10 \\
\hline Manatee & 164 & 121,000 & 26 & 30 \\
\hline Polk & 147 & 274,000 & 19 & 13 \\
\hline Sarasota & 274 & 161,000 & 35 & 30 \\
\hline
\end{tabular}

\subsubsection{Meteorology}

Mean annual precipitation in the central Florida phosphate district ranges between 50 to $65 \mathrm{in./yr}$. Due to its southern latitude, virtually all of central Florida's precipitation is in the form of rain rather than snow. Average surface runoff in the area is $15 \mathrm{in./yr}$. In addition, the phosphate district receives about $3,000 \mathrm{hr} / \mathrm{yr}$ of sunshine and has a mean annual pan evaporation of $70 \mathrm{in.}$ Annual temperatures average in the high $70 \mathrm{~s}$ with extremes ranging from freezing to over $100^{\circ} \mathrm{F}$.

Winds in central Florida seldom average more than $5 \mathrm{mph}$. Typically fall and winter winds are south to southwest while spring and summer winds are northwest. The average afternoon mixing depth at which pollutants disperse over the area ranges from 1.5 to $2.0 \mathrm{~km}$. Average wind speed through the mixing depth ranges from 6 to $8 \mathrm{~m}^{2} / \mathrm{sec}$. Ventilation resulting from this wind passing through the mixing depth has an annual range of 6,000 to $12,000 \mathrm{~m}^{2} / \mathrm{sec}$.

\section{1 .4 Ecology}

Phosphate deposits in central Florida lie on the southern fringes of the temperate deciduous biome. ${ }^{(3)}$ Dominant vegetation is magnolia-sweetbay-live oak forest. Also, stands of mangroves occur along coastal regions. Wet lands and low-lying areas are characterized by spike-rush and sawgrass. Dry land hammocks are typically covered with buttonbush and pond-apple. 
Game and wildlife characteristics of the area are listed in Table 6.2.

TABLE 6.2. Wildlife of Central Florida

$\begin{array}{ll}\text { Marsh Deer } & \text { Ducks } \\ \text { Raccoon } & \text { Heron } \\ \text { Snakes } & \text { Egret } \\ \text { Cotton Rat } & \text { Limpkins } \\ \text { Squirrel } & \text { Marsh Rabbit }\end{array}$

In addition to land animals and birds, many species of fish and other aquatic life occur in marsh lands and along coastal regions of central florida.

\subsubsection{Hydrology}

Because much of central Florida is close to sea level there is abundant ground and surface water in the region. Coastal plains are characterized by salt and brackish water marshes. Moreover, the majority of the area is typical of Florida "wet lands" with standing water at the surface or just below the surface.

Stratigraphic conditions in central Florida are also favorable to ground water circulation. Surface material is generally unconsolidated sand and grave 1 or other types alluvium that tend to form good aquifers. In addition, subsurface consolidated strata is composed of permeable carbonate rocks that allow formation of hydrologic systems.

Most ground and surface water in central Florida contain dissolved salts in concentrations usually over $150 \mathrm{ppm}$. Water near coastal regions tend to be saline or brackish. Inland waters that circulate through limestone and dolomite aquifers contain bicarbonate of calcium and magnesium.

\subsubsection{Geology and Mineralization}

Phosphate ores of central Florida were formed by both organic and inorganic depositional processes in shallow marine basins. Subsequent reworking of the sediments has led to economic concentrations by secondary enrichment. Typical stratigraphic sections of the ore matrix are composed of unconsolidated phosphate pebbles and clasts, with interstitial phosphate quartz sand

\section{5}


and silt as well as clay minerals. The phosphate deposits can range up to $80 \mathrm{ft}$ thick but are generally between 25 to $30 \mathrm{ft}$. Overburden ranges from 15 to $100 \mathrm{ft}$ thick with an average of $45 \mathrm{ft}$. (1)

A generally accepted model for the deposition of marine phosphorite is one of nutrient-rich sea water circulating through an embayment or shallow basin. Because phosphorous solubility is inversely related to water temperature, precipitation takes place when waters are warmed in shallow basins. In the central Florida deposits, nutrient-rich cool waters from the Gulf of Mexico were carried by currents into warm basins of the continental shelf where phosphate precipitation occurred. In addition to the inorganic chemical precipitation of phosphorous, shells of marine organisms containing phosphorous further enriched the sediments. Secondary geologic processes also increased phosphate concentration. Currents dislocated and aggregated clastic phosphate grains in bottom muds to form pellets containing as much as $20 \%$ of $\mathrm{P}_{2} \mathrm{O}^{\circ}$

Although marine phosphorites are a complex matrix, the phosphate and uranium are typically contained in the minerals listed in Table 6.3.

TABLE 6.3. Significant Minerals in Marine Phosphorite $(1,5)$

\begin{tabular}{lll}
\multicolumn{1}{c}{ Mineral } & & Composition \\
Carbonate-Fluorapatite & & $\mathrm{Ca}_{10}\left(\mathrm{PO}_{4}, \mathrm{CO}_{3}\right)_{6} \mathrm{~F}_{2}$ \\
Francolite & $\mathrm{Ca}_{5}\left(\mathrm{PO}_{4} \mathrm{~m} \mathrm{CO}_{3}\right)_{3}(\mathrm{~F}, \mathrm{OH})$
\end{tabular}

Uranium in sea water is incorporated into phosphorites either as a tetravalent ion $\left(U^{+4}\right)$ replacing $\mathrm{Ca}$ in the apatite structure, or as a uranyl ion $\left(\mathrm{UO}_{2}{ }^{+2}\right)$ being absorbed into apatite crystal surfaces. $(1,4)$ In the central Florida deposits uranium content ranges from 10 to $145 \mathrm{ppm}$ with an average of 65 ppm uranium. $(1,5)$

Total uranium contained in recoverable phosphate material in central Florida is estimated to be 460,000 short tons. Uranium contained in recoverable phosphate material in the U.S. is estimated to be $22,459,000$ short tons. 


\subsubsection{Mining}

Methods used to mine phosphate material in central Florida have been thoroughly described in current literature. $(1,6)$ Therefore, only brief descriptions will be presented here.

All mining of Florida phosphate deposits is done from the surface with either a dragline or dredge. In the dragline operation the prime mover will typically have a $40-$ to $60-y^{3}$ bucket and mine a strip from 200 to $300 \mathrm{ft}$ wide, several thousand feet long and up to $150 \mathrm{ft}$ deep. First, the overburden is stripped off and side cast into a parallel strip that has previously been mined. Next, the ore matrix is removed and dumped into a slurry pit to be mixed with water and transported by pipeline to the milling facility.

Dredging of phosphate material is done with tandem floating dredges. The front dredge removes overburden and pumps spoil to land reclamation areas behind the mining operation. Marketable ore is lifted with the rear dredge and hydraulically transported through pipelines to a processing plant. Both methods of phosphate mining are depicted in Figure 6.2.

Ore transportation from mine to mill is similar for both types of mining. Once the phosphate matrix reaches the surface it is screened to remove large rocks and debris and then slurried for transportation through a pipeline. Specifications for a typical ore slurry are given in Table 6.4.

\section{TABLE 6.4. Specifications of a Typical Florida Phosphate} Ore Transportation System

$\begin{array}{ll}\text { Debris Screen } & 6-\text { in. mesh } \\ \text { Slurry Solid Content } & 25 \text { to } 40 \% \text { by weight } \\ \text { Slurry Pipeline Diameter } & 14 \text { to } 20 \mathrm{in} . \\ \text { Pressure in Slurry Pipe } & 200 \mathrm{psi} \\ \text { Solids Velocity } & 12 \text { to } 15 \mathrm{ft} / \mathrm{sec} \\ \text { Water Requirements } & 5,000 \mathrm{to} 12,000 \mathrm{gal} / \mathrm{min} \\ \text { Slurry Capacity } & 1,200 \mathrm{short} \mathrm{tons} / \mathrm{hr} \\ \text { Transportation Distance } & 0.5 \text { to } 5+\mathrm{miles}\end{array}$



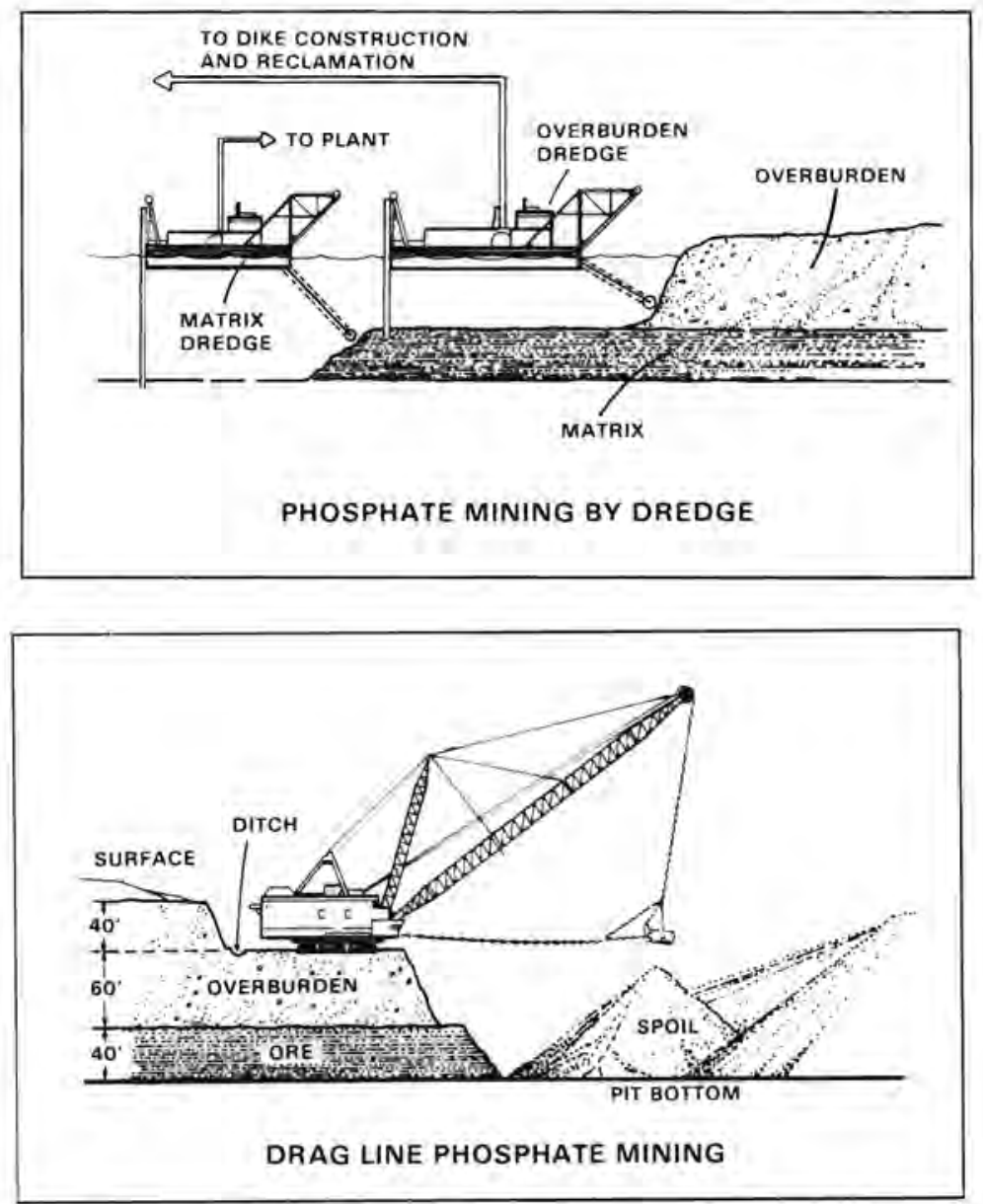

FIGURE 6.2. Phosphate Mining Methods

\subsubsection{Mining Generated Wastes and Controls}

The dredge mining operation in Florida produces 10,220,000 tons/yr of overburden. The average value of $1 \mathrm{ppm}$ of $\mathrm{U}_{3} \mathrm{O}_{8}$ in the overburden is low enough for disposal onsite to be no problem. The overburden is used as backfill in areas previously mined. As seen in Appendix B, the amount of radioactivity is quite small, especially on a per pound basis.

Due to the mining technique used (dredging), there is no dust being generated at the mine. The ore being dredged is transferred by pipeline to the mill. This eliminates the need for mine water control. Thus, there is no need of dust or water waste control equipment. The mine does not have any appreciable control costs. 


\section{1 .9 Milling Methods $(1)$}

The Florida phosphate mill processes the $65 \mathrm{ppm} \mathrm{U}_{3} \mathrm{O}_{8}$-bearing phosphate ore slurry from the dredging operation and produces $85 \% U_{3} 0_{8}$ powder. The slurry is received at the rate of 3,324 tons/hr from the dredging area. The mill is to operate $22 \mathrm{hr} /$ day, 350 days/yr. The basic process steps are shown in Figure 6.3 and described in detail below.

The slurry entering the mill is screened to separate the large ( +14 mesh) pebbles from the rest of the slurry. The undersized portion of the slurry is deslimed at 150 mesh in a series of cyclones. The waste slimes are removed from the system and pumped to the slimes pond. The underflow from the cyclone is sent to the ball mill for grinding. The large pebbles separated at the beginning of the circuit are passed through a hammermill and then sent to the cyclones described above. The ground rock ( -35 mesh) from the ball mill (65\% solids) is transferred to tanks for acidification.

The digestion process is performed using 93\% sulfuric acid. A series of holding tanks are needed to enable the leaching process to be completed over a six hour time period. After the digestion process the leach slurry is filtered and the solids washed free of dissolved uranium. The tailings are disposed of in the gypsum pond, so-called because the waste consists of gypsum and gangue material. The water from the gypsum pond is used in the counter current washing of the solids previously mentioned. After filtration the pregnant solution is treated with iron to aid in the extraction of the tetravalent uranium. Before extraction the solution is passed through a series of clarifiers and thickeners. At this time a scrub solution of kerosene is added to the reduced solution in order to remove any organics. Sand clarifiers remove the organic/kerosene emulsion immediately prior to the extraction circuit.

A solution of octyl phenyl phosphoric acid (OPAP) in kerosene extracts the uranium from the pregnant solution in a five stage series of mixer/settlers. The slurry from the extraction process is neutralized and disposed of in the phosphate pond. The loaded solvent solution contains $300 \mathrm{ppm} \mathrm{U}_{3} \mathrm{O}_{8}$ in 


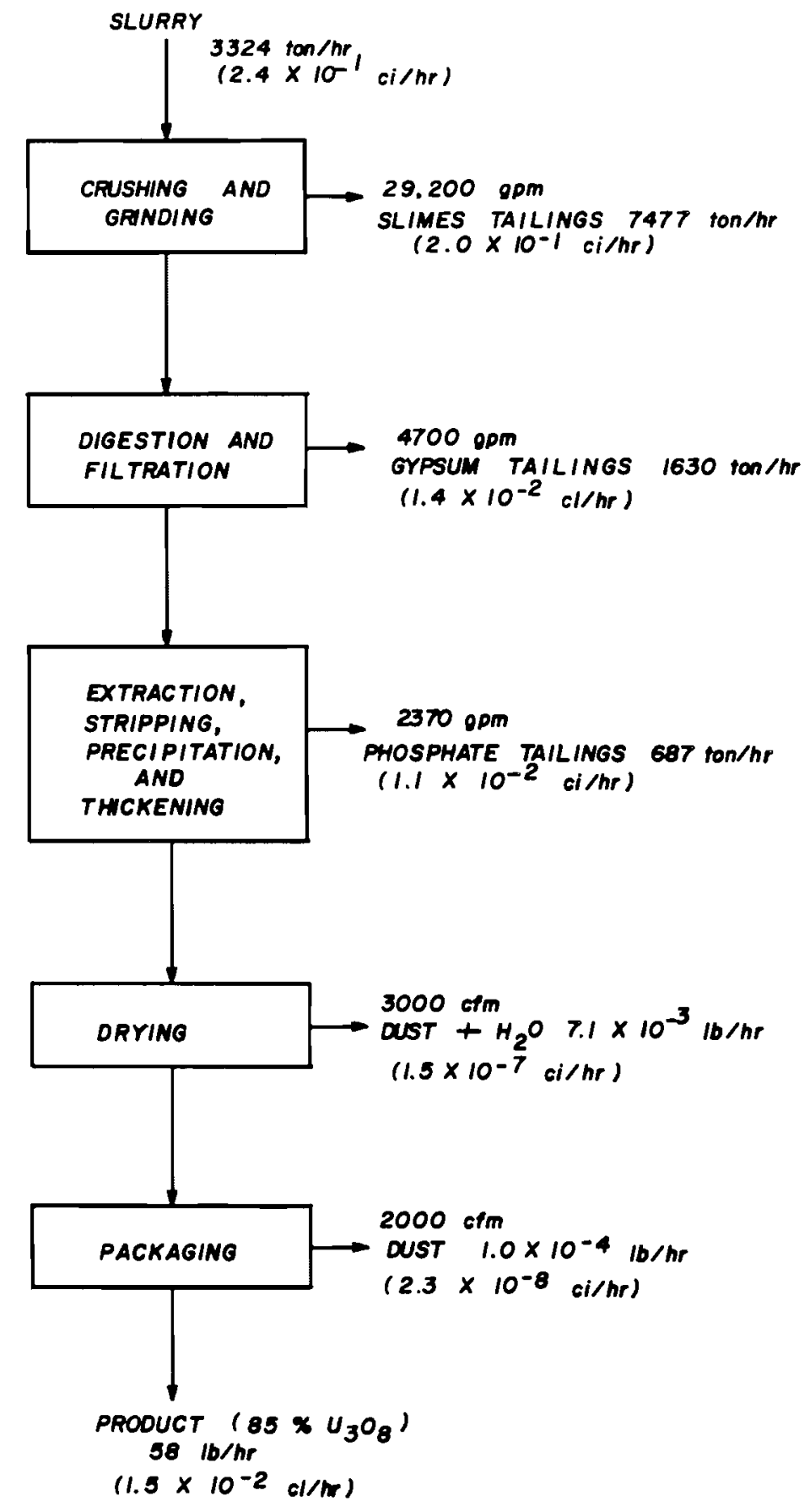

FIGURE 6.3. Florida Phosphate Mill Generated Wastes 
$0.3 \mathrm{~m}$ OPAP before stripping operations. Hydrogen peroxide and a $54 \%$ phosphoric acid solution are used in a series of four mixer/settlers to strip the loaded solvent of uranium. This loaded strip solution is diluted with water and has a concentration of $7,000 \mathrm{ppm} \mathrm{U}_{3} \mathrm{O}_{8}$ in the $30 \% \mathrm{P}_{2} \mathrm{O}_{5}$ acid solution. The diluted solution enters a series of four extraction mixer/settlers where a solution of di-2-ethyl hexyl phosphoric acid (DEHPA) and trioctylphosphine oxide (TOPO) dissolved in kerosene separates the uranium from the stripped solvent. This stripped solvent is regenerated and then recycled back to the extraction circuit. The loaded solvent solution has to be scrubbed free of impurities, such as iron and entrained phosphate ions, before the final stripping stages. A $10 \%$ sodium carbonate $\left(\mathrm{Na}_{2} \mathrm{CO}_{3}\right)$ solution is used to strip the uranium from the scrubbed loaded solvent. The final strip solution $\left(10 \% \mathrm{Na}_{2} \mathrm{CO}_{3}\right)$ contains $50,000 \mathrm{ppm} \mathrm{U}_{3} \mathrm{O}_{8}$.

The pregnant strip solution is pumped to acidification tanks where a $93 \%$ sulfuric acid $\left(\mathrm{H}_{2} \mathrm{SO}_{4}\right)$ solution is added in order to precipitate out the iron and other impurities. More acid is then added and the mixture is treated to expel $\mathrm{CO}_{2}$ gas. To precipitate the uranium as yellowcake, ammonia gas $\left(\mathrm{NH}_{3}\right)$ is added. The slurry is flocculated and thickened in a cone bottomed thickener. The slurry from the thickener is $25 \%$ solids and is centrifuged to remove some of the excess moisture.

The resulting $60 \%$ solids yellowcake slurry is dried at $500^{\circ} \mathrm{F}$ in a mechanically agitated dryer. The cooled product is discharged into 55-gal drums which hold $750 \mathrm{lb}$ each. The final product is $98 \%$ solids and $85 \% U_{3} \mathrm{O}_{8}$ yellowcake.

\subsubsection{Milling Generated Wastes and Controls}

The Florida phosphate mill produces four liquid waste streams and one dust stream. The detailed calculations of these waste streams and their levels of radioactivity are shown in Appendix $C$ and sumarized in Figure 6.3.

Since the incoming slurry from the mine is $70 \%$ water there is no dust emitted from the mill processes until the drying and packaging operations at the end of the mill. The amount of dust given off is quite small 
$\left(7.2 \times 10^{-3} \mathrm{lb} / \mathrm{hr}\right)$ with most of the streams being water from the drying process. The amount of $\mathrm{U}_{3} \mathrm{O}_{8}$ is $6.5 \times 10^{-4} \mathrm{lb} / \mathrm{hr}$ with a radioactive content of $2 \times 10^{-7} \mathrm{Ci} / \mathrm{hr}$.

As in the other mills, the gaseous waste stream from the drying process is treated separately from the packaging dust stream due to the large amount of water in the stream. The drying waste stream is treated using a 3,000-cfm wet impingement scrubber having a capital cost of $\$ 8,000$ and an annual cost of $\$ 5,000$. The packaging dust stream, though small, has to be controlled closely because its composition is the same as the product $\left(85 \% \mathrm{U}_{3} \mathrm{O}_{8}\right)$, which makes it valuable. To control the packaging dust a 2,000-cfm baghouse filter system is needed. This system has a capital cost of $\$ 13,000$ and an annual cost of $\$ 6,000$. All of the dust collected in the control systems is recycled back to the main mill processes.

The four liquid streams are disposed of in three separate areas for the first six months of plant life and after six months, two waste disposal areas are needed. The largest waste stream is the slimes tailings from the crushing and grinding operations. The flow rate is $29,200 \mathrm{gpm}$, at $4 \%$ solids, containing $72 \mathrm{lb} / \mathrm{hr}$ of $\mathrm{U}_{3} \mathrm{O}_{8}$. The radioactive release rate of this stream is $2.0 \mathrm{x}$ $10^{-1} \mathrm{Ci} / \mathrm{hr}$. For the first six months this stream is disposed of in a 20 -acre plastic lined settling pond. The majority of the water ( $\simeq 96 \%)$ will be recycled for use in the mill. After the first six months of operations the slimes tailings will be disposed of in the mine or dredge ditch. A distribution system will spread these tailings over the gypsum tailings also being disposed of there. The water will still be recycled for use in the mill, but at a lower rate $(\simeq 21,000 \mathrm{gpm})$. The capital cost of the settling pond, including the plastic liner and a pond cover of $6 \mathrm{ft}$ of earth and vegetation, is $\$ 1,000,000$ and the annual cost, prorated over a $20-y r$ period, is $\$ 200,000$. The capital cost of the recycle, distribution, and pumping and piping systems for the slimes tailings is $\$ 2,600,000$ and the annual cost is $\$ 1,200,000$.

The gypsum tailings are emitted from the digestion and filtration processes at the rate of $4,700 \mathrm{gpm}$ containing $50 \%$ solids and $5 \mathrm{lb} / \mathrm{hr} \mathrm{U}_{3} 0_{8}$. The radioactive release rate of this stream is $1.4 \times 10^{-2} \mathrm{Cj} / \mathrm{hr}$. Due to the high level of solids this stream can be disposed of in the mined out areas between the over- 
burden piles and behind the dredge. The water is recycled to the mill as required. After the first six months of operation the gypsum tailings will be covered with the slimes tailings. As one dredge section is filled the overburden will be used to cover the tailings. The capital cost of the above systems for handling the gypsum tailings is $\$ 1,100,000$ and the annual cost is $\$ 400,000$.

Two liquid waste streams from extraction and stripping, and precipitation and thickening flow into the phosphate pond. The total flow into the pond is $\approx 2,400 \mathrm{gpm}$ containing $4 \mathrm{lb} / \mathrm{hr}$ of $\mathrm{U}_{3} \mathrm{O}_{8}$. These streams pass through a limestone neutralizing system and then into the 120-acre, plastic lined phosphate pond. The tailings are centrifuged and piled in the central part of the pond to depths averaging $100 \mathrm{ft}$. The excess solution, after passing through a 20 -acre settling pond, is recycled back to the mill for reuse. The phosphates can be recovered quite easily and if this is done the overall cost of the pond system will be partially offset by this byproduct usage. The phosphate pond will have to be covered with 6-ft of earth and revegetated at a capital cost of $\$ 1,000,000$ and an annual sinking fund cost of $\$ 11,000$. The capital cost of the phosphate pond systems, less the pond cover, is $\$ 7,200,000$ and the annual cost is $\$ 2,200,000$.

Table 6.5 contains a complete cost breakdown for the above waste control systems. The capital cost of the controls is $\$ 13,070,000$ and the annual cost is $\$ 4,060,000$. The cost of the phosphate tailings control system, not including the pond cover, is 55\% of the total capital cost at the Florida phosphate mill and 55\% of the total annual costs. 
TABLE 6.5. Estimated Waste Control Costs for the Florida Phosphate Mill

\begin{tabular}{|c|c|c|c|}
\hline Generated Waste & Type of Control & $\begin{array}{c}\text { Capital } \\
\text { Cost }(\$ 1000) \\
\end{array}$ & $\begin{array}{c}\text { Annual } \\
\text { Cost }(\$ 1000)\end{array}$ \\
\hline Drying Dust & $\begin{array}{l}3,000 \text {-cfm wet impinge- } \\
\text { ment scrubber system }\end{array}$ & 8 & 5 \\
\hline Packaging Dust & $\begin{array}{l}2,000-c f m \text { baghouse } \\
\text { filter system }\end{array}$ & 13 & 6 \\
\hline Slime Tailings & $\begin{array}{l}20 \text {-acre plastic lined } \\
\text { pond } w / \text { recycle system } \\
\text { and } 6 \mathrm{ft} \text { earth cover } \\
\text { and vegetation }\end{array}$ & 3,640 & 1,410 \\
\hline Gypsum Tailings & $\begin{array}{l}\text { Return to mined out } \\
\text { areas, distribute, and } \\
\text { recycle water }\end{array}$ & 1,120 & 410 \\
\hline Phosphate Tailings & $\begin{array}{l}120 \text {-acre plastic lined } \\
\text { pond } w / 20 \text {-acre settling } \\
\text { pond and recycle system }\end{array}$ & 7,210 & 2,220 \\
\hline $\begin{array}{l}\text { Phosphate Pond Radioactivity } \\
\text { Total Costs }\end{array}$ & $\begin{array}{l}6-\mathrm{ft} \text { earth cover with } \\
\text { vegetation }(120 \text { acres) }\end{array}$ & $\frac{1,080}{13,070}$ & $\frac{11}{4,060}$ \\
\hline
\end{tabular}

\subsection{REFERENCES}

1. DeVoto, R. H. and D. N. Stevens (eds.). 1979. Uraniferous Phosphate Resources and Technology and Economics of Uranium Recovery from Phosphate Resources, U.S. and Free World. GJBX-110(79), Earth Sciences, Inc., Grand Junction, Colorado, •

2. U.S. Department of Commerce. 1977. County and City Data Book. U.S. Department of Commerce, Bureau of the Census, Washington D.C.

3. Shelford, V. E. 1963. The Ecology of North America. University of Illinois Press, Urbana, Illinois.

4. Cathcart, J. B. 1978. "Uranium in Phosphate Rock." USGS Professional paper 988-A, Washington, D.C.

5. Stowasser, W. F. 1979. "Phosphate, Mineral Commodity Profiles." U.S. Bureau of Mines, Washington, D.C.

6. "Zellars, M. E. and J. M. Williams. 1978. Evaluation of the Phosphate Deposits of Florida Using the Minerals Availability System." Prepared for the U.S. Bureau of Mines by Zellars-Williams, Inc., Lakeland, Florida. 


\subsection{ASSESSMENT OF AVAILABLE ENVIRONMENTAL CONTROL TECHNOLOGIES}

Environmental control technologies were reviewed in current literature and discussed with suppliers of commercial equipment. There are many methods available to control generated wastes. The selection of the best methods to use depend upon the processes employed and site-specific data. Equipment and facilities selected for environmental control are determined during the detailed feasibility and environmental impact studies for the specific site.

Typical types of wastes that must be controlled are shown in Figure 7.1. The tailings pile, which contains the bulk of the radioactivity, is the main source of concern for offsite release of effluents after operations cease.

The uranium industry will be associated with a wide range of processes, chemicals, by-products, locations, geologies, etc. Environmental control methods used at one site may not be suitable at another site. The various methods of controlling wastes are discussed in the following subsections.

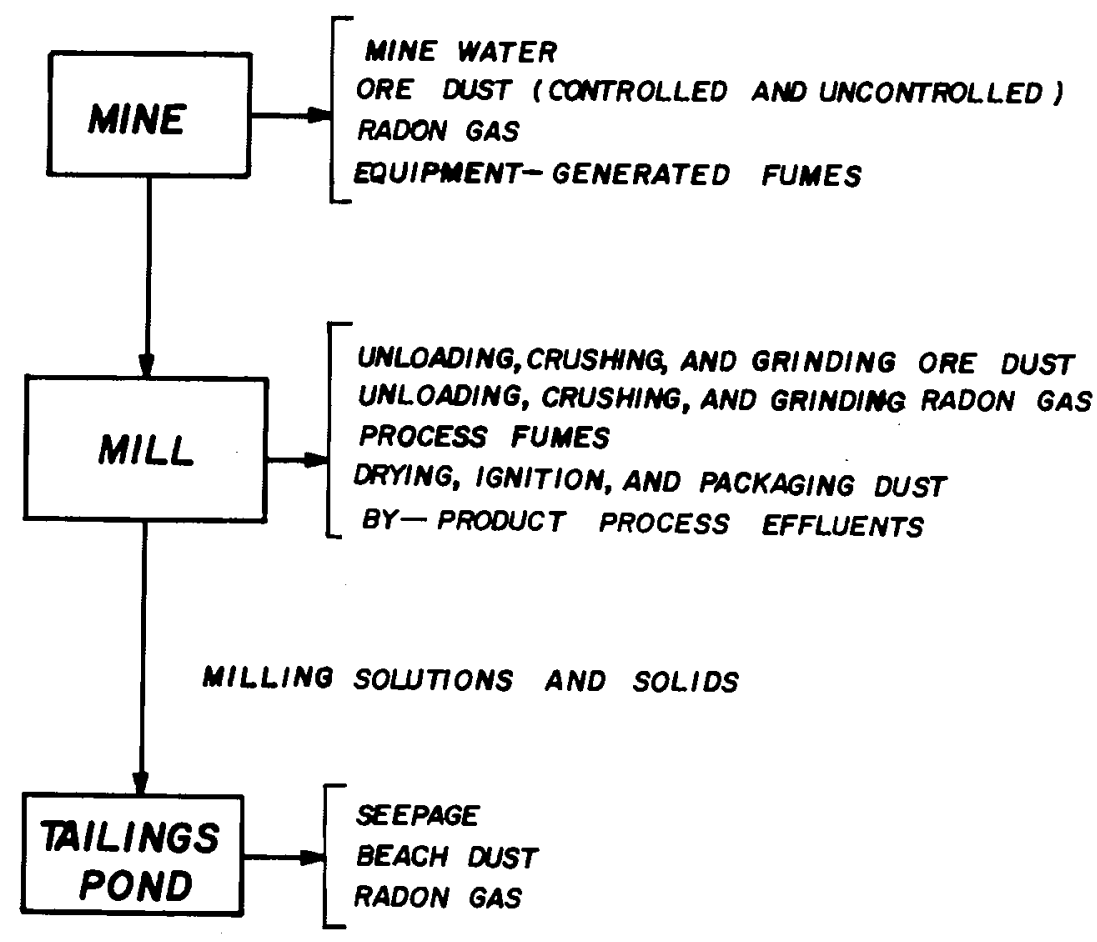

FIGURE 7.1. Typical Types of Wastes from Mining and Milling of Uranium 
Wastes can be controlled to different levels by methods that are now in various stages of development, effectiveness and costs of the methods, which are addressed in Section 8 , are site and ore specific.

\subsection{METHODS OF ENVIRONMENTAL CONTROL FOR MINING}

Uranium is mined in both underground and surface mines. The generated wastes with the largest chance of offsite release from the mine are:

- Untreated mine water that can reach underground aquifers or surface waters

- Ore dust generated from drilling, blasting, and materials handling operations, and dust generated by the wind and vehicles from roads, yards, and ore storage piles

- Radon gas released from the ore during mining, handling, and storage

- Fumes generated by the equipment (e.g., diesel engines).

Underground mine dust, the radon released, and the fumes generated by equipment are more controllable because the mine ventilation is used to collect and channel the wastes. The methods of controlling mine water and wastes outside the underground area are similar for both types of mines. The biggest problem at either type of mine is the control of radon gas. In an underground mine, it is feasible (but prohibitively expensive) to reduce the radon effluent level, but releases in open-pit mines are essentially impossible to control.

\subsubsection{Mine Water Control}

Standard mining practices will be used to channel mine water in a way that will minimize pollution due to erosion. Water treatment may be required in some cases where the turbidity, dissolved radioactive material content, acidity, or heavy metals content are high. Mine water can be utilized in milling operations when they are located nearby and can also be used to control the release of dust from onsite roads, ore piles, materials handling, and drilling and blasting operations. 
Mine water will usually be collected and possibly treated in a settling pond prior to subsequent use or discharge into natural surface waters or drainage systems. Flocculation and clarification ${ }^{(1)}$ can be employed, when needed, to reduce the total solids in solution, the chemical oxygen demand, and the radium content. Flocculants are water-soluble organic polyelectrolytes that are sometimes used with inorganic coagulants and/or coagulant aids to agglomerate solids suspended in aqueous systems. The flocculation process collects colloidal particles into larger and more dense aggregates, which then settle more rapidly and more completely in the clarification step. The choice of the specific chemicals used in the process depends upon the characteristics of the waste.

Ion exchange ${ }^{(1)}$ can be used to remove uranium from mine water. It also has been used to remove radium but not much is known about the process. The exchange of ions by means of a synthetic resin is a proven method of reducing dissolved solids contained in water. Uranium has been successfully extracted from mine water and $\mathrm{m} 111$ ore leach pulp.

Barium salt coprecipitation can be used in the pond to precipitate the radium out of the liquid streams. In the past, the common salts used along with a flocculant for coprecipitation of radium were $\mathrm{BaSO}_{4}, \mathrm{BaCO}_{3}$, and $\mathrm{BaCl}_{2}$ salt solutions. The relative effectiveness of barium salts is shown in Table 7.1. (2) Barium chloride has been the most effective and its product is relatively insoluble.

Lime precipitation $(1,2)$ can be used in settling ponds. The lime will help precipitate out heavy metals and increase the $\mathrm{pH}$. Neutralization with lime also tends to remove radium from the waste stream (up to $90 \%$ in highly acidic solutions).

In the unlikely event that mine water cannot be treated to meet environmental discharge requirements, it will be necessary to collect and evaporate the water with an evaporator or in a pond. The collected solids could be buried after operations cease by either covering the pond or moving them to the mill tailings pond or an approved landfill. 
TABLE 7.1. Radium Decontamination Using Barium Salts(a)

\begin{tabular}{|c|c|c|c|c|c|}
\hline \multirow[b]{2}{*}{$\begin{array}{c}\text { Effluent } \\
\mathrm{pH} \\
\end{array}$} & \multirow[b]{2}{*}{ Reagent } & \multirow{2}{*}{$\begin{array}{l}\text { Reagent } \\
\text { Addition } \\
\mathrm{g} / 1 \\
\end{array}$} & \multicolumn{2}{|c|}{$\begin{array}{l}\text { Radium Concentration } \\
\text { Ci } \times 10^{-5} / \mathrm{ml} \\
\end{array}$} & \multirow{2}{*}{$\begin{array}{c}\text { Radium } \\
\text { Removal } \\
\% \\
\end{array}$} \\
\hline & & & $\begin{array}{l}\text { Before } \\
\text { Treatment }\end{array}$ & $\begin{array}{c}\text { After } \\
\text { Treatment }\end{array}$ & \\
\hline \multirow[t]{8}{*}{ Neutral } & \multirow[t]{2}{*}{$\mathrm{BaSO}_{4}$} & 0.3 & 10 & 3 & 70 \\
\hline & & 1.0 & 30 & 7 & 77 \\
\hline & \multirow[t]{2}{*}{$\mathrm{BaCO}_{3}$} & 0.1 & 47 & 3 & 94 \\
\hline & & 0.2 & 49 & 4 & 92 \\
\hline & \multirow[t]{4}{*}{$\mathrm{BaCl}_{2}$} & 0.03 & 80 & 2 & 97 \\
\hline & & 0.06 & 44 & 0.6 & 99 \\
\hline & & 0.1 & 40 & 0.2 & 99 \\
\hline & & 0.2 & 43 & 0.2 & 99 \\
\hline \multirow[t]{4}{*}{ Acidic } & \multirow[t]{3}{*}{$\mathrm{BaCO}_{3}$} & 0.1 & $15^{(b)}$ & $1.8^{(\mathrm{c})}$ & $88^{(c)}$ \\
\hline & & 0.2 & $15^{(b)}$ & $2.0^{(\mathrm{c})}$ & $87^{(c)}$ \\
\hline & & 0.3 & $15^{(b)}$ & $3.0^{(\mathrm{c})}$ & $80^{(c)}$ \\
\hline & $\mathrm{BaCl}_{2}$ & 0.1 & $15^{(b)}$ & 0.5 to 1.5 & 90 to 97 \\
\hline
\end{tabular}

\footnotetext{
(a) Mill-scale tests, Union Carbide Corporation, Uravan, Colorado. (b) Average several sampling periods; individual samples erratic. (c) Differences in results not considered significant.
}

Some uranium mines are very dry and have no mine water to dispose of; so water must be transported to the site for drilling and blasting operations.

\section{1 .2 Ore Dust}

\subsubsection{Controlled Ore Dust}

Dust generated in an underground mine can be categorized as controlled dust. The underground mine's ventilation system helps to control dust at safe working levels for the workers. Auxiliary exhausts can be used where drilling, blasting, and materials handling generate larger quantities of dust. Water is used to reduce the dust from drilling. Blankets and water spray curtains can 
also be used to tie down the dust from blasting and materials handling. The use of the latest equipment and the best standard operating procedures will help control the dust.

The dust carries with it uranium, radium, and other alpha and beta emitters. (3) Contamination levels at any place and time depend on the ore grade, the type of operations involved, moisture, ventilation, and other such factors. Generally, where low-grade ore is mined and ventilation is good, contamination levels in uranium mines are well within the prescribed levels. Mines that produce high-grade ore have been known to have substantially higher levels of contamination.

The dust collected and discharged through the underground mine ventilation system can be passed through dust collection equipment if it is deemed necessary. Types of dust collection equipment that could be used are discussed in Section 7.2.1.

\subsubsection{Uncontrolled Ore Dust}

In a surface mine, the ore dust generated by the drilling, blasting, and handling operations is not as major a concern as it is underground. Use of the best equipment and best procedures will minimize the amount of dust generated.

Dust suppression is necessary for both surface and underground mines in these surface areas:

- roads

- yards

- ore stockpiles

- mine loading and mill unloading areas.

Road and yard dust can be minimized by periodically spraying surfaces with water and chemicals. The ore stockpiles can be protected from the prevailing winds by erecting wind barriers ${ }^{(4)}$ and, if necessary, by periodically wetting them or encrusting them with chemicals. Loading and unloading areas can also be protected from the wind, and spray curtains can be used if necessary. 


\subsubsection{Radon Gas Control}

In open-pit mines, there is little that can be done to control the release of radon to the environment. Radon is continually diluted in air and does not build up or accumulate like it could in unventilated areas of underground mines; however, it is necessary to monitor radon in surface mines during periods of air stagnation and thermal inversions. Most of the concern is about the radon daughters because they present a hazard to the workers' health when inhaled. Underground mines must rely on ventilation systems to prevent the accumulation of radon and its daughter products in the mine. Ventilation systems also dilute the concentration of these products with air to meet effluent discharge requirements for the mine.

In underground mines, the ambient concentration of radon is a function of barometric pressure variations, rock porosity, the volume of water seepage, the volume of ventilation, and, to a surprisingly minor extent, ore grade. Emanation rates of radon from mine walls and rocks may be estimated to determine which control measures to use and to establish design ventilation requirements. Large quantities of ventilation air, required to meet the federal standards for radon decay products within the mines, result in the discharge to the atmosphere of large air volumes with low radioactive concentrations. The immediate, large dilution of mine air by atmospheric air and the remote locations of the mines prevent any significant exposure to anyone. Normally, no special waste control equipment is needed to limit the discharge of radon and its decay products.

The radon will be swept in the mine ventilation exhaust system as it is released from the mine. By continuously operating the ventilation system in the working areas, a radon buildup can be prevented and the deposit of its daughters can be reduced.

The amount of radon and its daughters being released to the environment via the ventilation system $c$ an be reduced by delaying the gas and filtering out the daughter particles in the exhaust system. The particulates can be collected by high-efficiency particulate-air (HEPA) filters before the air is discharged. Activated charcoal-filter delay traps could be used to collect 
essentially all of the radon $(99 \%+)$. After the radon decays to the particulate daughter products, it will be released from the carbon filter and pass to the HEPA filter where $99.97 \%$ of the particulate will be collected. In the event that charcoal and HEPA filters are used, it will be necessary to install a baghouse filter upstream to catch the bulk of the dust. However, because of the tremendous size and cost to install and operate the system, it is not considered practical.

Use of refrigeration traps for collecting radon gas is also not practical due to the large air flow rates and costs.

\subsubsection{Control of Equipment-Generated Fumes}

No special methods will be used in the surface mines and all equipment (e.g., diesel engine) is assumed to utilize standard exhaust systems that meet or exceed EPA requirements. In the underground mines, the equipment fumes will be collected in the mine ventilation exhaust systems and diluted with excess air to meet EPA requirements.

\subsection{METHODS OF ENVIRONMENTAL CONTROL FOR MILLING URANIUM}

The generated wastes from the mill complex that may be released include:

- dust in the mill from unloading, crushing, and grinding the ore

- dust from drying, ignition, and packaging the uranium concentrate

- radon gas released while the ore is unloaded, crushed, and ground in the mill

- process fumes

- tailings pond seepage

- tailings pond beach dust

- radioactivity in the tailings pond after the mill/refinery closes.

Airborne dust from the mill/refinery operations can be controlled with well-developed equipment. Control of radon from crushing and grinding operations in the mill (through the use of carbon and HEPA filters) is feasible but very expensive. 
Environmental control at the tailings pond, both during and after operations, still results in highest costs in the milling operation. Low-cost control methods that are effective against pond water seepage during operations need to be developed, as well as methods of curtailing long-term radon release after the mill operations cease.

\subsubsection{Control of Mill Dust from Unloading, Crushing, and Grinding Ore}

A large variety of well-developed equipment is available to control the mill dust. The equipment is gradually being improved and, as a result of recent emphasis on environmental control, more specialized equipment is on the market today. The application, location, ore characteristics, process selected, and other factors can determine the optimum choice of equipment. Probably no two plants will select the same equipment because of process and site-specific considerations.

The main types of dust collection equipment considered in this report are listed below. The list does not include all of the types of dust collectors that should be considered but is simply a cross section of equipment with various efficiencies. New pieces of equipment, hybrids of various types, are also coming onto the market.

The dust collector should be selected after the process and plant layout is determined. Tests should be run with typical ore and conditions at the site to narrow down the equipment choice. Even with preliminary full-scale tests, circumstances as a result of site-specific variables (e.g., ore moisture content, size fractions, climate extremes, etc.) may require equipment changes after actual installation in the plant.

The types of dust collectors ${ }^{(5)}$ included in this study are as follows:

- cyclone

- orifice scrubber

- wet-impingement scrubber (irrigated target)

- low-energy venturi scrubber

- high-energy venturi scrubber

- baghouse filter

- HEPA filter

- others. 


\subsubsection{Cyclone Dust Collector}

A cyclone removes particulates from the air by converting the inlet stream into a double vortex within the cyclone. Figure 7.2 illustrates a cyclone dust collector. ${ }^{(6)}$ The primary vortex is formed as the inlet gas spirals downward and causes a layer of dust to slowly swirl down the walls and collect in the bottom of the hopper. Centrifugal force is the mechanism that acts to separate the particles. After the air reaches the bottom, the vortex reverses its axial direction and passes through the outlet. Multiple cyclones are simply two or more cyclones either in series or parallel. A single cyclone will have a collection efficiency of about $50 \%$ for 5 -micron particles while multiple cyclones are up to $90 \%$ efficient.

A cyclone is simple in design and, therefore, has a relatively low cost. The collection efficiency is also relatively poor for particles below 10 microns in size. The cost of installing a 30,000-cfm cyclone is in the $\$ 0.50$ to $\$ 1.00 / \mathrm{cfm}$ range.

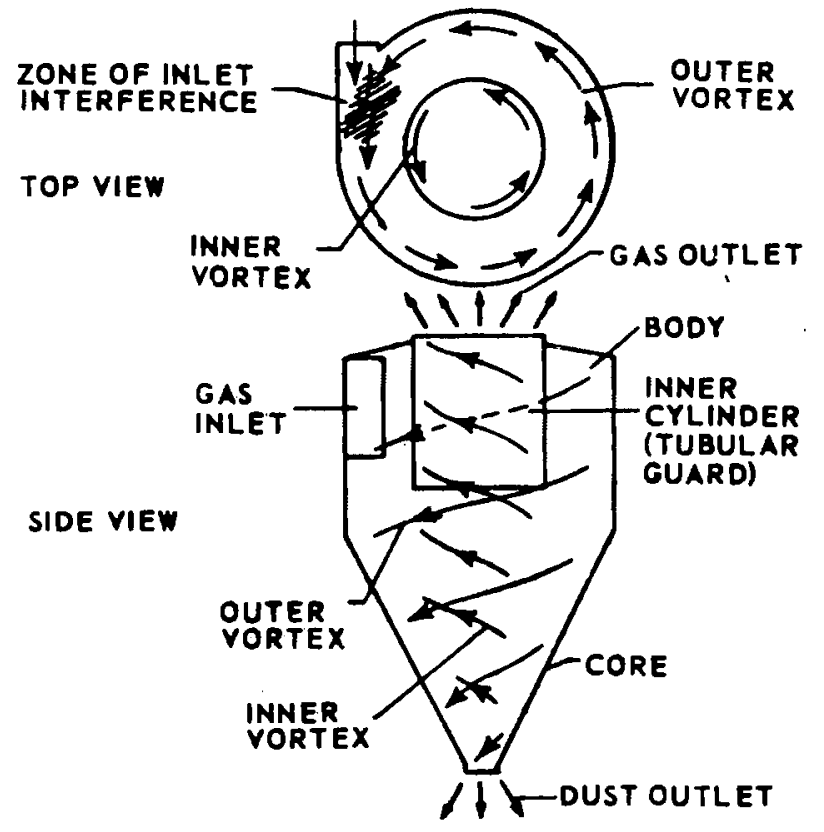

FIGURE 7.2. Cyclone (6) $^{(6)}$ 


\subsubsection{Orifice Scrubber Dust Collector $(4,5)$}

Orifice scrubbers have been widely used in the uranium industry. An example of an orifice scrubber is shown in Figure 7.3. Its principle of operation is that high-velocity air impinges on a pool of scrubbing liquor. The air flows through a baffle at high velocity while carrying water in a heavy turbulent sheet. The rapid change in direction causes a centrifugal force that makes the dust particles penetrate and adhere to the water film.
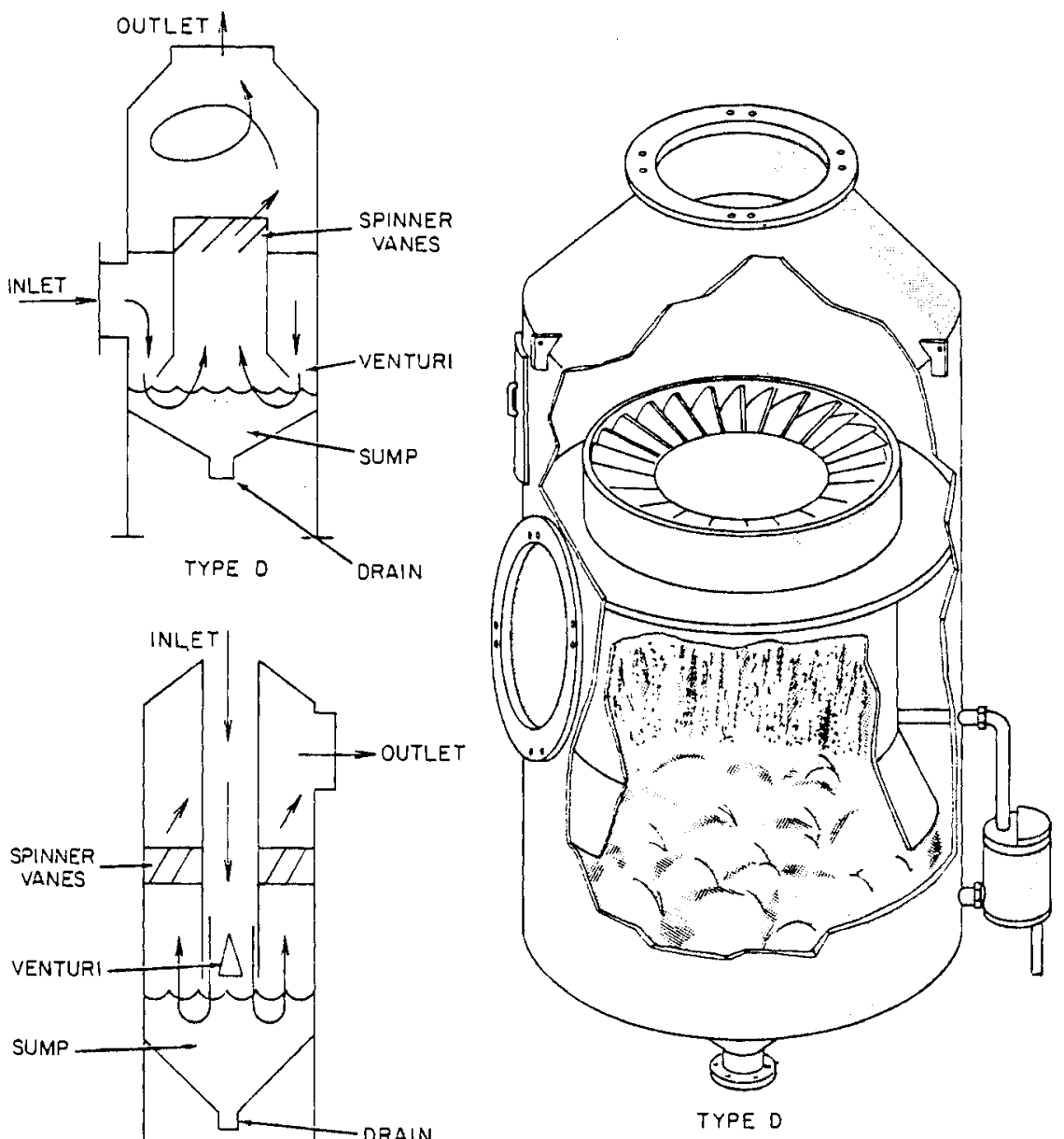

FIGURE 7.3. Orifice Scrubber (represented with permission from Environmental Engineers Handbook, Vol. 2 Air Pollution, Bela Liptak, Chilton Book Company, Radnor, Pennsylvania, 1974.) 
It has a dust collection efficiency of about $94 \%$ with 5 -micron particles. The efficiency is reduced by about $50 \%$ for 1 -micron sized particles. Installation costs range from approximately $\$ 1$ to $\$ 2 / \mathrm{cfm}$ for a 30,000 -cfm orifice scrubber system.

\subsubsection{Wet-Impingement Scrubber Dust Collector (Irrigated Target)}

Figure 7.4 demonstrates a type of wet-impingement scrubber. (7) The air stream is accelerated to a high velocity while passing through orifices, then impinged upon baffle plates. The dust particles are collected on vaned mist eliminators and are withdrawn, along with the solids collected, in the liquid overflow from the impingement plate. It has an efficiency of about $98 \%$ for 5-micron particles, which drops to about $80 \%$ for 1-micron particles. For a 30,000 -cfm unit, the cost ranges from about $\$ 1.50$ to $\$ 2.50 /$ cfm installed.

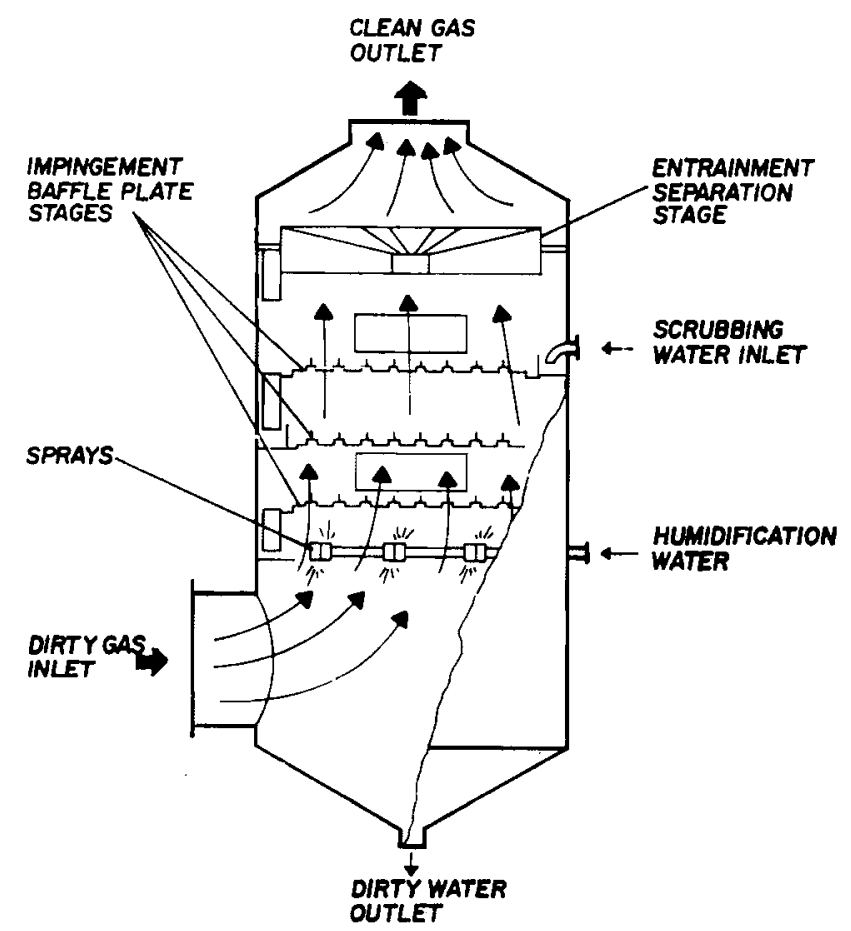

FIGURE 7.4. Wet-Impingement Scrubber (reprinted with permission from Pollution Engineering Practice Handbook, Cheremisinoff and Young, Ann Arbor Science Publishers, Inc., Ann Arbor, MI, 1976, p. 126.) 


\subsubsection{Low- and High-Energy Venturi Scrubber Dust Collectors}

An example of a venturi scrubber is given in Figure 7.5. (6) Its principle of operation is that high-velocity air impinges on the liquid stream in the throat of a venturi-shaped section and atomizes the liquid into fine droplets, on which the dust particles are collected. The gas stream continues into a cyclonic separator where the particle-laden scrubbing liquor and the air are thoroughly separated by centrifugal force to complete the cleaning operation.

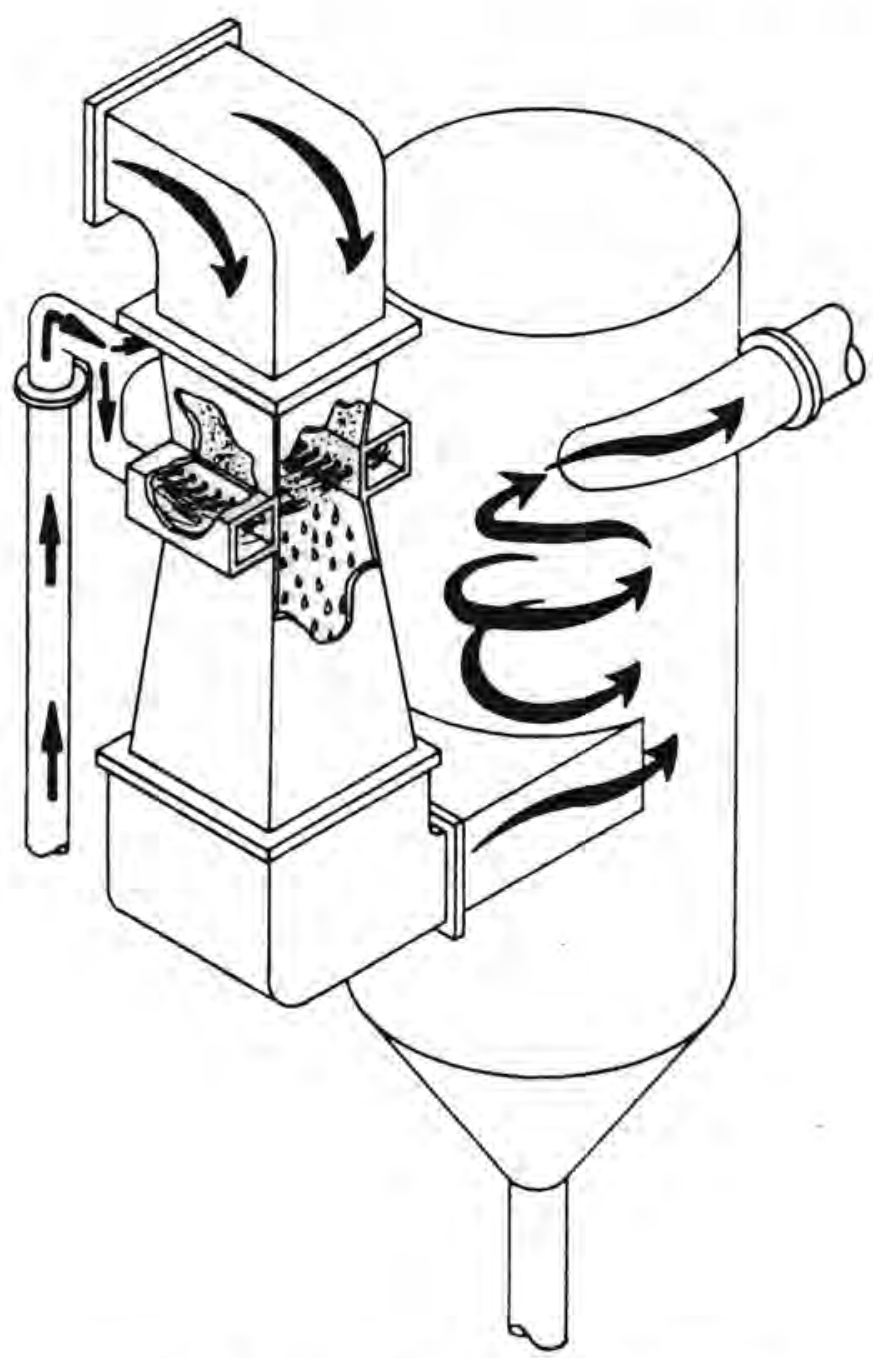

FIGURE 7.5. Venturi Scrubber ${ }^{(6)}$ 
Both the low-energy and high-energy units collect over $99 \%$ of the 5-micron size particles. The low-energy units collect up to $96 \%$ of the 1 -micron size particles and the high-energy unit collect up to $98 \%$. The low-energy unit will cost in the $\$ 1.75$ to $\$ 2.75 / \mathrm{cfm}$ range. A high-energy unit costs $\$ 2$ to $\$ 3 / \mathrm{cfm}$. The operating costs are relatively high for these units. The highenergy unit is especially costly because of the large amounts of power needed to compensate for the high pressure drop across the venturi.

\subsubsection{Baghouse Filter Dust Collector}

In the baghouse filter dust collector, illustrated in Figure $7.6,(6)$ the dust-laden air flows through a porous woven or felted fabric where it deposits the particulates in the voids. The pressure drop gradually increases as the voids are filled. When it is necessary to clean the bags, this is accomplished by mechanical action such as shaking the bags or reverse-air-jet pulsing. The dust falls into a hopper for subsequent disposal or recycling in the process. The particulates are collected dry and in a usable condition, so recovery is relatively easy. Bag filters operate best with relatively dry air streams. They cannot be used on such moist streams as the dryer off-gas.

Bag filters have an efficiency rating of up to $99.9 \%$; some of the bags are even very efficient in removing submicron particles from the air. The installed cost of a simple 30,000-cfm baghouse filter system with shakers is about $\$ 3$ to $\$ 5 / \mathrm{cfm}$. Costs can be substantially higher if special bags, sophisticated cleaning methods, special alloys, etc., are needed.

\subsubsection{HEPA Filter Dust Collectors}

High-efficiency particulate air (HEPA) filters, shown in Figure 7.7 , can be used downstream of a baghouse filter to reduce the release of particulates by practically 100\%. Even small 0.3-micron size particles are removed with up to $99.97 \%$ efficiency. Excessive moisture, however, can impair the HEPA filter's efficiency. The periodic buildup of particulates require the removal and replacement of the HEPA filter units.

HEPA filters have been used for many years in the nuclear industry to effectively remove radioactive particulates from gas streams. Use of this type of filter in the mining industry was not found during our review. 


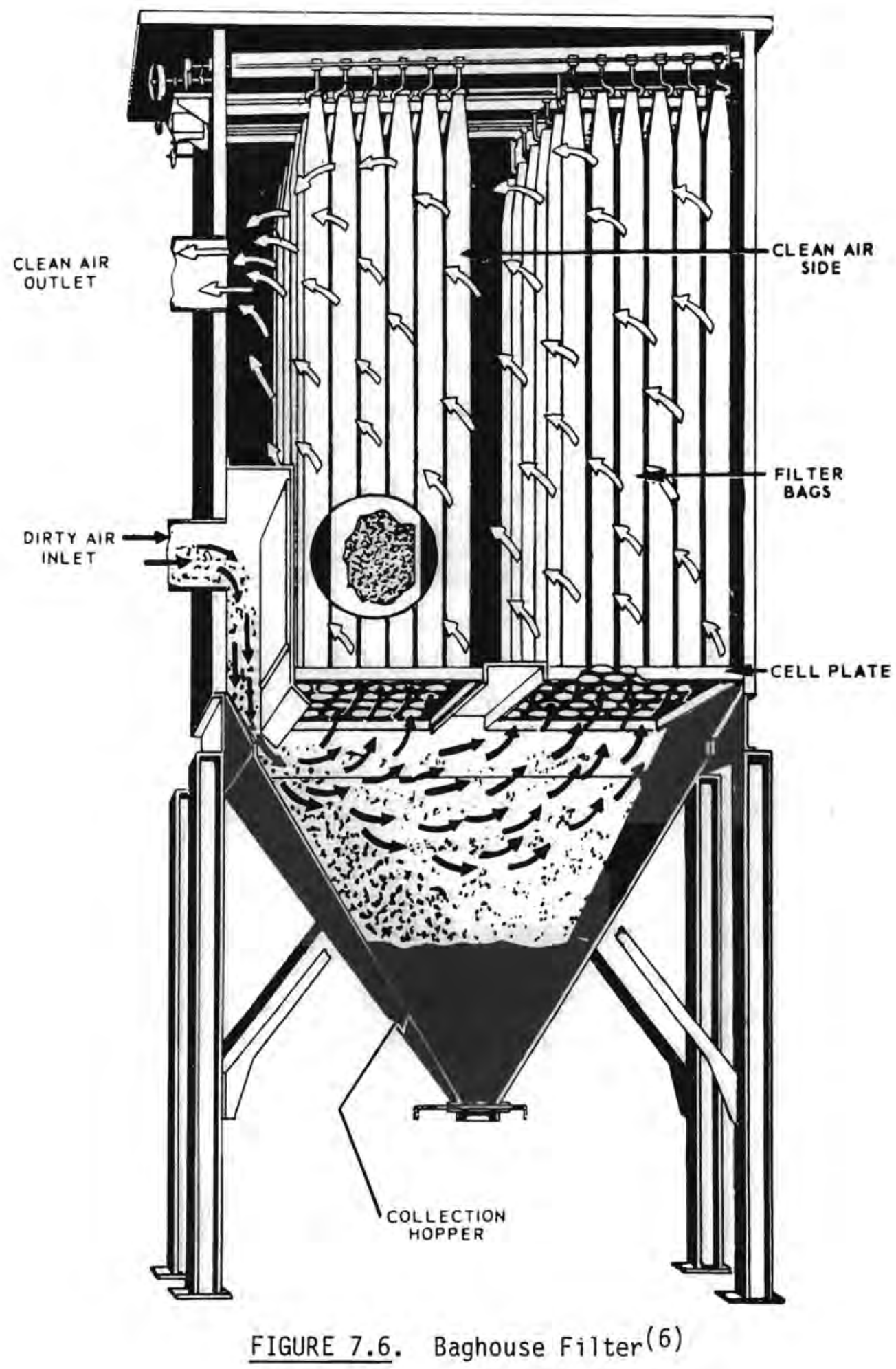




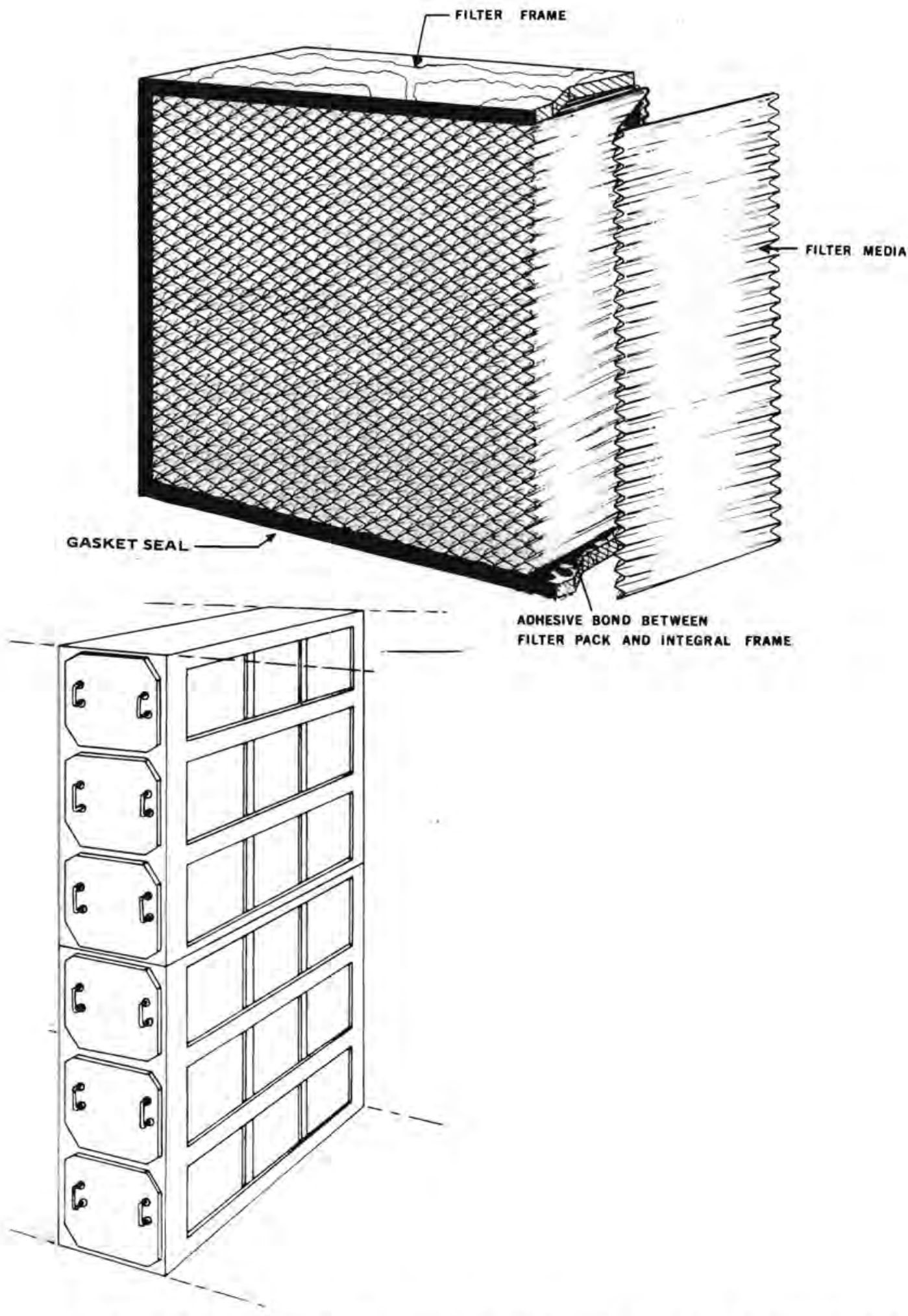

FIGURE 7.7. HEPA Filter and Manifold Housing for Multiple Filters (reprinted with permission from Flanders Air Filtration Products Catalog, Flanders Filters, Washington, NC.) 
Each HEPA filter has a capacity of about 1,000 to $3,000 \mathrm{cfm}$. For large air flows, it is necessary to arrange them in a parallel battery arrangement in a manifold housing, which spreads the air flow. The cost estimate for a $30,000-c f m$ unit installed would range from $\$ 6$ to $\$ 10 / \mathrm{cfm}$.

\subsubsection{0ther Types of Dust Collectors}

There are many designs for each type of dust collector discussed so far; there are also many other types of dust collectors that have not been discussed. Some collectors are hybrids of different types; others are continually in the process of being designed and developed. Therefore, a more thorough review of available equipment should be made after site-specific data and ore samples are available for testing.

To select the proper dust collection equipment for a given site, it will be necessary--as a minimum--to know the following types of data:

- application

- volume, temperature, and moisture content at inlet

- inlet variations and outlet conditions

- corrosive characteristics

- particle size distribution of the dust

- dust grain loading

- physical and chemical characteristics of the material being collected

- cooling and heating requirement, if any

- scrubbing liquid characteristics and availability

- climate.

\subsubsection{Control of Dust from Drying, Ignition, and Packaging Uranium Concentrate}

Essentially $100 \%$ of the daughters of uranium are removed from the uranium at this point in the process. The bulk of the particulates released from these process steps are uranium and water. While mostly water is given off in the drying and ignition steps, uranium concentrate dust is the only waste exhausted from the packaging hoods.

Wet-type dust collectors such as orifice, wet-impingement, low-energy venturi, and high-energy venturi scrubbers can be used for the wastes from 
drying and ignition. Dry-type collectors, such as baghouse and HEPA filters, are used for the packaging operations. Dust in this area is more radioactive and, therefore, it is impractical to use low-efficiency collectors like cyclones. The recovery of uranium particulates in this area of the refinery will sometimes more than pay for the dust collection equipment and operations involved.

\subsubsection{Control of Radon Gas from Unloading, Crushing, and Grinding}

Radon gas is released when the ore is crushed and ground. It will be difficult to control without the use of a delaying mechanism. Wet scrubbing solutions might collect some of the gas (tests are needed to verify how much).

Activated charcoal filters or refrigeration traps could be used to collect radon gas from the exhaust stream. The filter system would be similar to the one mentioned earlier for the underground mine exhaust. However, due to the high cost of the system and because the releases are within permissible limits, it is not considered practical to use the systems.

\subsubsection{Process Fume Control}

The processes considered in this study do not generate sufficient fumes to warrant the use of waste control equipment. Minor fumes will be generated from low-temperature acids, kerosene, diesel, and other chemicals, but they can be handled with conventional ventilation equipment stacks.

In cases where high-temperature acids or other chemicals are used, it will be necessary to use fume scrubbers. Venturi scrubbers, packed-bed scrubbers, or mist eliminators can be used to control the fumes. They can be installed at a cost of $\$ 1$ to $\$ 4 / \mathrm{cfm}$.

\subsubsection{Tailings Seepage Control}

The seepage of liquid through the pond bottom and dam is still common at many uranium tailings ponds. Seepage rates ${ }^{(8)}$ of 0 to $25 \%$ of the total input to the ponds have been reported. This seepage may be to the groundwater and/or to surface drainage. At many sites, some of the seepage is recovered in ditches or catch basins below the dam and pumped back to the pond. The 
newest mills have clay-core dams ${ }^{(4)}$ where seepage has not been observed. One new mill was projecting $12 \%$ to $27 \%$ seepage $^{(11)}$ even with a clay-core dam. This study has assumed the use of clay-core dams as its base technology. Seepage from the tailings pond is generally minimized by a combination of proper site selection and careful design of the pond and dam.

The geological permeability at some sites will make it necessary to line pond bottoms with clay, asphalt, rubber liners, etc., to minimize or eliminate seepage. Neutralization of acidic mill water may be required to protect some of the liners (e.g., asphalt). Some of the main factors to be considered in evaluating the pond liners are:

- resistance to subsidence of subsoil and rock

- resistance to chemical attack from tailings fluid

- resistance to physical penetration (man, equipment, animals, waves, wind)

- resistance to weathering (freeze-thaw, bakeout, ultraviolet light, ozone)

- liner permeability

- liner aging

- microbial resistance

- liner pressure differential effects (water head, gas generation, etc.).

In addition to geological and liner factors, the coarseness of the tailings solids can have an influence on the seepage rates. (11) Finer particulates fill in voids and reduce seepage rates.

Other methods of reducing seepage involve dewatering the tailings and burying them as sludge or as blends with concrete or asphalt. Excess water can be eliminated by evaporation in a lined pond or an evaporator, recycled to the mill, or some combination. Residue from the excess water would be collected and processed along with the tailings at the termination of the mill's operation. 
Some innovations for handling mill tailings were presented at the recent annual uranium industry seminar. (10) Additional innovations are encouraged since it is recognized that the problems of developing tailings management and disposal plans are highly site-specific.

\subsubsection{Clay-Core Dam}

The base technology assumes that a dam is constructed across a natural valley or basin to impound the mill tailings and solutions. The dam is constructed of compacted borrow material with a clay core that is keyed to an impervious rock strata or clay at the base of the dam. Diversion ditches will be constructed to handle natural runoff around the impoundment. The pond bottom will be scarfed to remove topsoil that can be used in later reclamation procedures. The bottom will be contoured, smoothed--as much as practicable, and compacted. Hopefully, the site will have a native clay base.

A distribution system, such as a movable piping network, tremie rafts, a small dredge, etc., will be used to spread out the tailings and maintain a water cover on the tailings at all times. At all of the sites included in this study (except the Thomas Caldera deposit in Utah), a substantial amount of excess water is available to maintain a water cover over the tailings. The water cover will hold radon emanation to very low levels.

Some of the excess water (up to $100 \%$ ) will be reused in the mill after passing through an auxiliary settling pond. Extra treatment of the recycle water, such as the addition of flocculants, lime, or barium chloride, may be required but they were not included in this study's costs.

The use of a clay-core dam should reduce seepage to 0 to $15 \%$. However, at some sites this low a seepage rate cannot be achieved even with clay-core dams. (11) The cost for a 100-acre tailings pond, distribution system, and recycling system would be about $\$ 3,000,000$.

\subsubsection{Clay-Core Dam with Clay Liner}

This case is the same as the base technology case except a 3-ft compacted clay liner is added to the bottom and the dam interface. It is important to 
keep the clay from drying out and cracking. It is assumed that good impermeable clay is readily available within a few miles of the site. If it is not, the clay-liner option would have to be carefully studied and compared to other options. Additives that will make some permeable clays more impermeable (e.g., bentonite) are being developed but there is not enough information for their costs and effectiveness to be projected.

The addition of a clay liner should reduce the seepage rate down to a 0 to $3 \%$ range. The cost of adding a 3-ft clay liner to a 100-acre dam would be a minimum of about $\$ 350,000$. If the clay is mined offsite and must be shipped to the site, this will add considerably to the cost.

\subsubsection{Clay-Core Dam with Asphalt Liner}

Except for the added asphalt liner and the neutralization plant, this case is the same as the base technology case. A 2-in. asphalt liner is laid on top of a 4-in. rock base over the entire pond bottom and the dam interface. A neutralization plant has also been added to neutralize the tailings acid water before it is exposed to the asphalt. The asphalt liner should reduce the seepage to less than $1 \%$. The cost for a 100-acre liner will be about $\$ 2,350,000$. The cost of the neutralizaton plant will be about $\$ 800,000$. The development of asphalt emulsions ${ }^{(9)}$ to line the ponds may reduce the cost of liners appreciably in the future.

\subsubsection{Clay-Core Dam with Rubber Liner}

A 60-mil multi-ply rubber (hypalon or equivalent) liner is used to cover the bottom and dam surfaces of the tailings pond. In this process, extra care is taken to smooth the contours of the land and to remove sharp objects that might penetrate the liner. Venting is added where natural gas might be a problem. If the rubber liners are well cared for and protected from foot and vehicular traffic, they should provide essentially $0 \%$ leakage for the life of the mill. The cost of lining a 100-acre pond with 60-mil hypalon would be about $\$ 3,250,000$. 


\subsubsection{Dewater Tailings, Convey to Landfill}

A clay-core dam will not be required in this case. A landfill pit well above the ground water is excavated and lined with about $3 \mathrm{ft}$ of clay. The tailings stream will pass through neutralization, thickening, and vacuum filter steps to dewater the tailings. A covered conveyor belt system carries the tailings to the landfill. The excess water is pumped to a hypalon-lined storage pond. The water is recycled to the mill after passing through an auxiliary settling pond. Solids from the storage and settling ponds are transferred to the landfill when the mill is decomissioned.

The cost of a 100-acre landfill pit to serve a 1000-ton/day mill would be about $\$ 7,100,000$. If a mined-out area can be used in lieu of excavating a landfill pit, about $\$ 2,000,000$ would be saved. At some sites, using trucks to haul the dewatered tailings to the landfill might also save money. Seepage from the tailings should be less than $1 \%$ for this option.

\subsubsection{Dewater Tailings, Blend with 10\% Cement, Pump to Landfill}

A clay-lined landfill pit is used in lieu of a tailings pond to dispose of the tailings. The pit is lined with $3 \mathrm{ft}$ of clay. The mill tailings stream passes through a neutralizing and thickening step where the solids are removed in a slurry. The slurry is mixed with about 1 part cement to 10 parts solids, then the slurry is pumped to the landfill where it is allowed to solidify. The decanted water from the thickener is pumped to a hypalon-lined storage pond. The water is recycled to the mill after passing through a secondary settling pond. Seepage from the original tailings effluents should be close to zero. After the $\mathrm{mill}$ is shut down, solids from the storage and settling pond are processed through the cement slurry plant for burial in the landfill.

For a 1000-ton/day plant, the installation cost of the above system will be $\$ 5,200,000$. Annual costs will be about $\$ 3,400,000$. The use of a mined-out pit or mounding (piling tailings on clay pads) could save about $\$ 2,000,000$ in excavation costs. Mounding was used in this study due to the large volumes used. 


\subsubsection{Dewater Tailings, Blend with 40\% Asphalt, Convey to Landfill}

Tailing solids are blended with asphalt and disposed of in an unlined landfill pit or mound above the water table. The mill waste solutions are neutralized with slaked lime, dewatered in a thickener, and concentrated by a continuous filter. The tailing solids are blended with about $40 \%$ asphalt in an asphalt fixation plant, then the blend is conveyed to the landfill by a belt conveyor where it is dumped and compacted. The asphalt coats the tailing particles with a coating that is relatively impervious to leaching and radon migration. The decanted water is processed for recycling, as in the other dewatered tailing cases.

The installation cost of the system outlined above is about $\$ 12,400,000$ for a 1000-ton/day mill. If excavation can be eliminated, a cost savings of about $\$ 3,500,000$ would be achieved. Mounding on top of natural earth surfaces was the method used in this study because of the large volumes of tailings required. The annual cost will be extremely high, about $\$ 19,000,000$, primarily due to the cost of the asphalt material.

\subsubsection{Tailings Pond Beach Dust Control}

Beach dust will be much less of a problem in the cases where tailings solids are dewatered and buried. The water storage pond liners will have to be periodically washed down around the water's perimeter.

In the cases where tailings ponds are used, more beach surface area will be exposed and will require more treatment. Unlined and clay-lined pond beaches will have to be periodically sprayed with chemical coating agents using portable equipment to tie down the dust washed up by waves. Beaches around ponds lined with asphalt or hypalon will probably require hosing down with water as a minimum. The cost of portable spray equipment is estimated at about $\$ 20,000$ for a 100-acre tailings pond. The effectiveness can be very good if the spraying is administered at the proper times.

As previously mentioned, the tailings are maintained underwater and thus there will be no exposed tailings pile to treat. The processes assumed in this study generated a large tailings solution-to-solids ratio and, since most of the sites selected were not in arid parts of the country, they must either 
recycle water or add hundreds of extra acres to the ponds' size to assure adequate evaporation of the water. Recycling conserves the water; so there is also enough extra water to maintain a head over the tailings despite variations in mill waste rates, seasonal evaporation rates, retention system designs, and other cyclic factors.

\subsubsection{Tailings Pond Radon Gas Control}

Release of radon gas from the pond during the mill's operating life will be controlled by the same methods as the tailings dust: the tailings are kept underwater and the beaches are periodically cleaned or sprayed with crusting chemicals.

After the mill ceases its operations, the pond will be allowed to evaporate, leaving the tailings exposed once again. As soon as tailings become exposed, they will be confined with chemicals or sprayed with water for an interim period. After the tailings are sufficiently dry, they will be covered with an appropriate cover in accordance with existing regulations for longterm stabilization of the radon, tailings, and radioactivity. The long-term stabilization procedures are discussed in the following section.

\subsubsection{Long-Term Stabilization of the Tailings}

After the mill ceases operation, the tailings are stabilized by covering them. However, stabilization of the tailings in the landfill cases will progress as fast as the landfill is filled.

The bulk of the radioactivity from the original mined ore is located in the tailings. This includes the radioactivity from the small percentage of unrecovered uranium and from uranium daughters that were originally in equilibrium with the uranium. Thorium and its daughters may also be included at some of the sites. The daughters of thorium-232 all have much shorter halflives than the daughters of uranium-238. Thus, it is a great deal easier to stabilize thorium wastes than it is to stabilize uranium wastes. The uranium daughters, thorium-230 and radium-226, have long half-lives and thus the tailings must be stabilized for a much longer time. The method of stabilization used will depend upon site specific factors. Some sites with low grade ore may require little, if any, cover. 
The pile should be leveled just prior to being covered. The cover should be crowned slightly in the middle to allow natural drainage away from the tailings and, thus, reduce the chance of leaching radioactive constituents into the groundwater. The cover should prevent radioactive particles from migrating and reduce the emanation of radon to near background levels. The cover should also be thick enough to reduce above-ground radiation levels to as close as possible to background levels.

Besides contouring the cover to prevent the accumulation of runoff above the tailings, ditches and diversion dams should be installed to permanently control the runoff from the surrounding land. Most of the diversion system will be installed before the mill commences initial production.

The cover should have adequate protection from erosion by the wind and run-off water and from burrowing ground rodents. The cover can be topped with either rocks or vegetation. Rock riprap will prevent utilization of the land and protect the cover from wind erosion. Rock covers are especially suitable where moisture is inadequate to support vegetation.

Vegetation can be added to stabilize the cover, providing topsoil is also placed on the cover. Vegetation can probably be used at most of the uranium mining sites discussed in this study because adequate moisture is available. Care must be taken to avoid plant vegetation that will provide a path for the migration of radium and radon through the soil or roots. Where roots are likely to penetrate the tailings, it may be necessary to install a barrier such as an asphalt lining, rubber lining, or other means hostile to the growth of vegetation into the tailings.

The cover may also incorporate a rubber lining, asphalt layer, or compacted-clay layer to reduce the permeability of the cover. The use of such layers will reduce the leaching potential of the tailings and will also substantially reduce the thickness of the earth cover needed to prevent radon emanation.

In this study, a variety of covers for the tailings were considered. They included 6- and 12-ft earth covers; an added 1-ft compacted clay cover, 
an added 1-in. asphalt cover, and an added 60-mil hypalon (or equivalent) cover; and an added rock or vegetation topping.

Costs for a 100-acre tailings pond cover range from $\$ 920,000$ for $6 \mathrm{ft}$ of earth topped with $6 \mathrm{in}$. rock to about $\$ 4,870,000$ for $60-\mathrm{mil}$ hypalon and 12-ft of earth, topped with 6 in. of rock.

The costs for the rock topping are slightly higher than for the vegetation if no maintenance is required. If vegetation maintenance is required, that option will likely be the more costly in the long run. Costs will vary considerably between sites, especially if the rock or topsoil have to be mined offsite.

\subsection{REFERENCES}

1. Environmental Protection Agency. 1975. Group II, Development Document for Interim Final and Proposed Effluent Limitation Guidelines and New Source Performance Standards for the Ore Mining and Dressing Industry, EPA 440/1-75/061, Environmental Protection Agency, Washington, D.C.

2. Merritt, R. C. 1971. The Extractive Metallurgy of Uranium, Library of Congress 71-157076, Colorado School of Mines Research Institute, Golden, Colorado.

3. "Radiation Protection in Mining and Milling of Uranium and Thorium." 1976. Proceedings from International Symposium. ISBN 92-2-101504-1, IL0 Publications, $\mathrm{CH}-1211$ Geneva 22, Switzerland.

4. Sears, M. B. et al. 1975. Correlation of Radioactive Waste Treatment Costs and the Environmental Impact of Waste Effluents in the Nuclear Fuel Cycle for Use in Establishing "As Low as Practicable" Guides - Milling of Uranium Ores, ORNL-TM-4903, Vol. 1, Oak Ridge National Laboratory, Oak Ridge, Tennessee.

5. Liptak, B. G. 1974. Environmental Engineers Handbook, Volume 2: Air Pollution, Chilton Book Company, Radnor, Pennsylvania.

6. Engineering-Science, Inc. 1973. Field Surveillance and Enforcement Guide for Primary Metalurgical Industries, PB-230, 898, prepared for the Environmental Protection Agency, National Technical Information Service, Springfield, Virginia.

7. Cheremisinoff, P. N. and R. A. Young. 1976. Pollution Engineering Practice Handbook (2nd edition), Ann Arbor Science Publishers, Inc., Ann Arbor, Michigan. 
8. Hendricks, D. W. 1977. U.S. Environmental Protection Agency, Uranium Mill Tailings Storage, Use and Disposal Problems, Paper at Conference on Uranium Mining Technology, Reno, Nevada.

9. Koehmstedt, P. L., J. N. Hartley and D. K. Davis. 1977. Use of Asphalt Emulsion Sealants to Conta in Radon and Radium in Uranium Tailings, BNWL-2190, Pacific Northwest Laboratory, Richland, Washington.

10. Martin, J. B. 1978. Update of NRC Uranium Mill Licensing Activities, Paper presented at Annual Uranium Industry Seminar, Grand Junction, Colorado.

11. U. S. Nuclear Regulatory Commission. 1977. Operation of Bear Creek Project, Rocky Mountain Energy Company Docket No. 40-8452, PB-267 375 National Technical Information Service, Springfield, Virginia. 


\subsection{RELATIVE COST AND EFFECTIVENESS ESTIMATES FOR ENVIRONMENTAL CONTROL TECHNOLOGIES}

The cost and effectiveness of the technologies discussed in the previous section are estimated for the mining and milling of the various uranium resources outlined in this section. These estimates can be used for preliminary planning and analysis but more accurate costs and estimates of effectiveness will have to be determined during the site-specific feasibility and environmental impact studies or during the preliminary plant design.

The estimates are based on a general review of the current literature ${ }^{(1,2,3,4,5)}$ and augmented by discussions with sales engineers in some cases. The vendors all cautioned that, in order to make accurate $( \pm 30 \%)$ estimates, it is necessary to have an accurate assessment of process and layout, thorough ore characterization, and site-specific (e.g., climate, geology, water availability, etc.) and other data available. Preliminary laboratory and full-scale tests should also be run when practicable. Sometimes, even with thorough advance testing, some surprises occur at the startup of production. Production downtime alone may be of enough importance to sway a decision on which method or system to use.

The control methods analyzed in this study represent a cross-sectional comparision of methods in various stages of advancement. Because the technology of dust collection is well advanced, there is a wide selection of hardware designs. The dust collection methods included in this study represent a selection of some of the many methods, which range in efficiency from high to low. On the other hand, the technology for tailings storage is not as well advanced. Both conventional tailings storage methods and more advanced, but less tested, methods have been included in this study.

The estimated cost range for the four uranium resource sites considered in this study are summarized in Table 8.1.

Table 8.1 indicates that the range of costs at each site can vary by up to two orders of magnitude. The lower end of the cost spectrum represents the 
TABLE 8.1. Cost Range for Environmental Control for the Mining and Milling of Various Uranium Resources

\begin{tabular}{lrl}
\multicolumn{1}{c}{ Location } & & $\begin{array}{r}\text { Approximate Cost Range } \\
\text { Cost/lb of } U_{3} 0_{8} \text { Produced }\end{array}(\mathrm{a}, \mathrm{b})$ \\
\cline { 1 - 1 } Chattanooga Shale, Tennessee & & $\$ 21.67$ to $\$ 902.60$ \\
Bokan Mountain, Alaska & & $\$ 20.61$ to $1,308.33$ \\
Thomas Caldera, Utah & & $\$ 21.60$ to $1,343.37$ \\
Phosphates, Central Florida & $\$ 10.74$ to $1,343.49$
\end{tabular}

(a) Minimum cost represents the base technology, which is usually the most available, lowest cost, and simplest to employ (e.g., equipment constructed of mild steel, easy to move soil, good onsite availability of construction materials, no special protection from the environment, low contingency, etc.).

(b) Maximum cost is for the more effective but usually more complex methods. These methods, which have been considered for current conventional uranium resources, are probably unnecessary and far too costly for the lower grade ore resources used in this study. Contingency costs of up to $200 \%$ could apply, but were not included in these figures.

use of the most simple, least costly, and usually least effective environmental control technologies. In this study, the lowest cost represents the base technology case. The upper end of the cost spectrum utilizes the most sophisticated, most costly, and usually most effective technologies. However, some of the more advanced and costly technologies will require testing and actual use in the field before their effectiveness can be accurately assessed. The large contingency of up to $200 \%$ can apply because geologies may have adverse variations, special materials may be required in equipment construction, or larger equipment capacities or additional equipment may be required due to the nature of the ore or processes selected.

Tables $8.2,8.3,8.4$, and 8.5 contain estimates of the capital cost, annual cost, relative effectiveness, and technology confidence level for each generated waste and environmental control method assumed. The base technology 
method for each waste is identified in the tables. The cost summaries for Tables $8.2,8.3,8.4$, and 8.5 cannot be directly compared to each other because they contain data for different types of resources that use different processes.

Table 8.2 summarizes data for the Chattanooga shale underground mine resources. The shale has a low grade of $0.0065 \%$ of $\mathrm{U}_{3} \mathrm{O}_{8}$. The size of the mines assumed in this study are much larger than any underground mines currently in existence. Therefore, the mining operations themselves, would require a substantial advancement in technology. The base case assumption was for $66 \%$ of the tailings to be pumped back to mined out areas for disposal. That procedure has uncertain environmental consequences. The tailings volumes are so huge that all disposals must be examined under close scrutiny. The majority of the environmental control cost ( $80 \%$ or more) occurs in tailings control and stabilization. Due to the low grade of ore, it may be possible to reduce costs by using less than a 6 -ft earth cover without incurring excessive radioactivity and radon emanation. If by-products like syncrude, sulfur, vanadium, nickel, cobalt, etc. are also recovered, the cost of environmental control can be prorated against them and thus reduce costs charged to uranium. Table 8.2 indicates, as do Tables 8.3, 8.4 and 8.5, that the capital and annual costs increase along with the effectiveness of the environmental control technologies used. The majority of the costs occur in the tailings disposal and control area and, as seen in the tables, the cost of combining tailings with asphalt or cement are prohibitively expensive.

Table 8.3 summarizes the data for another underground mine located at Bokan Mountain, Alaska, which has an average grade of $0.003 \%$ of $\mathrm{U}_{3} \mathrm{O}_{8}$. Technological problems which occur at the Chattanooga shale resource also apply here. Due to the remoteness of this resource, costs are likely to be higher than those shown in the table.

Table 8.4 provides the cost and effectiveness estimates for the Thomas Caldera mine deposit in Utah. The average ore grade $\left(0.003 \% U_{3} 0_{8}\right)$ is the same as for the Bokan Mountain deposit. No mining technology problems should occur because the mine is open pit. This resource is located in a dry arid area with small water resources. Dust control receives considérable attention. 

TABLE 8.2. Cost and Effectiveness of Environmental Control Technologies at the Chattanooga Shale Mine and Mill (Tennessee)

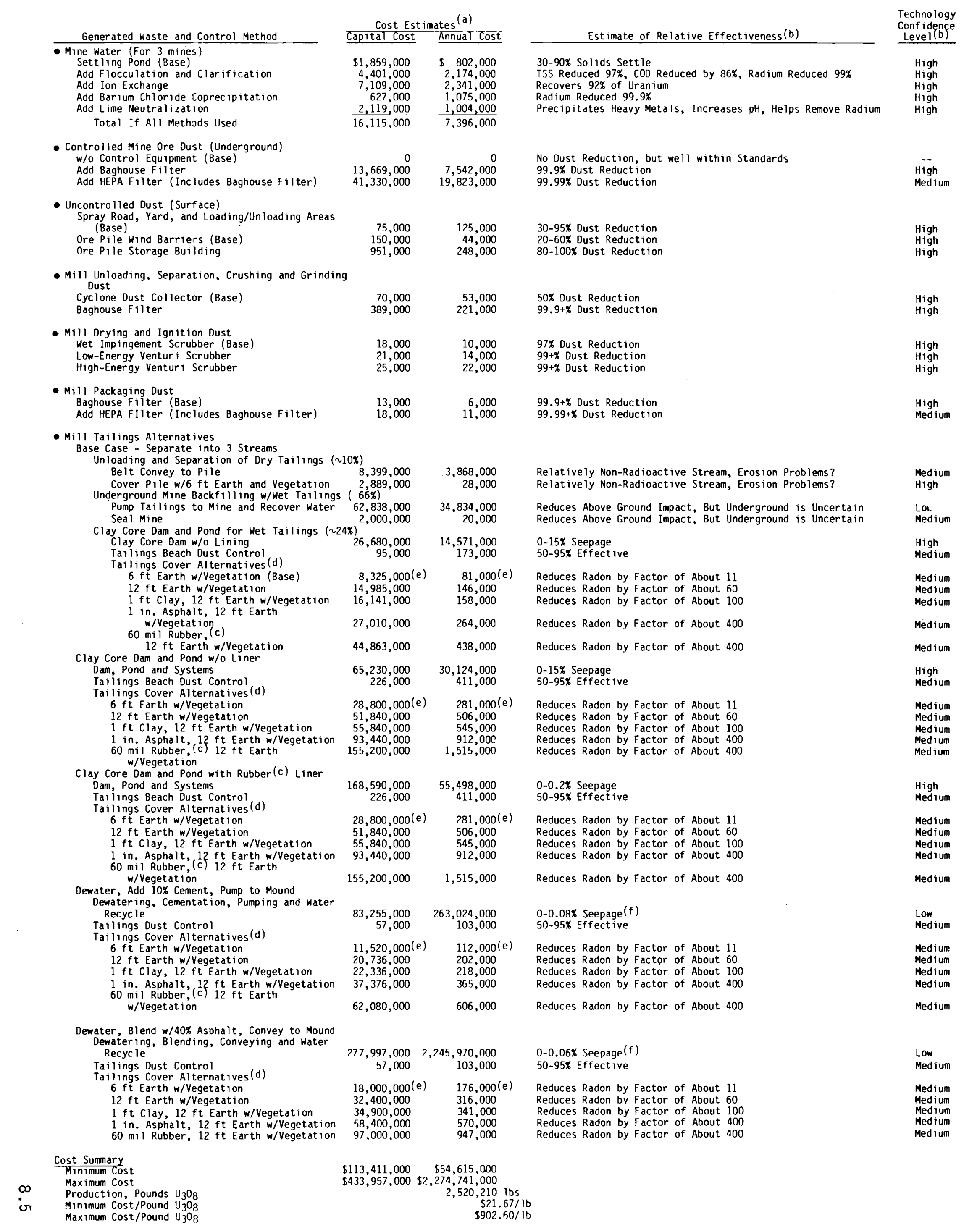

Notes: (a) Costs could go up to 3 times higher than these for some sites because of variables in site and process characteristics.

(d) All of these cases should hold material. Radioactivity levels should be close to background.

Assumptions: $6 \mathrm{ft}$ Earth reduces radon emanation by factor of 11 from no cover.

$12 \mathrm{ft}$ Earth reduces radon emanation by $\mathrm{factor}$ of $60 \mathrm{fra}$

$60 \mathrm{mil}$ Rubber is equivalent to 1 in. Asphalt.

(e) Tailings cover capital costs are incurred af ter the mill closes down. A sinking fund is establisher to pay for the cover.
(f) Includes an allowance for water storage pond leakage also. 

TABLE 8.3. Cost and Effectiveness of Environmental Control Technologies at the Bokan Mountain Mine and Mill (Alaska)

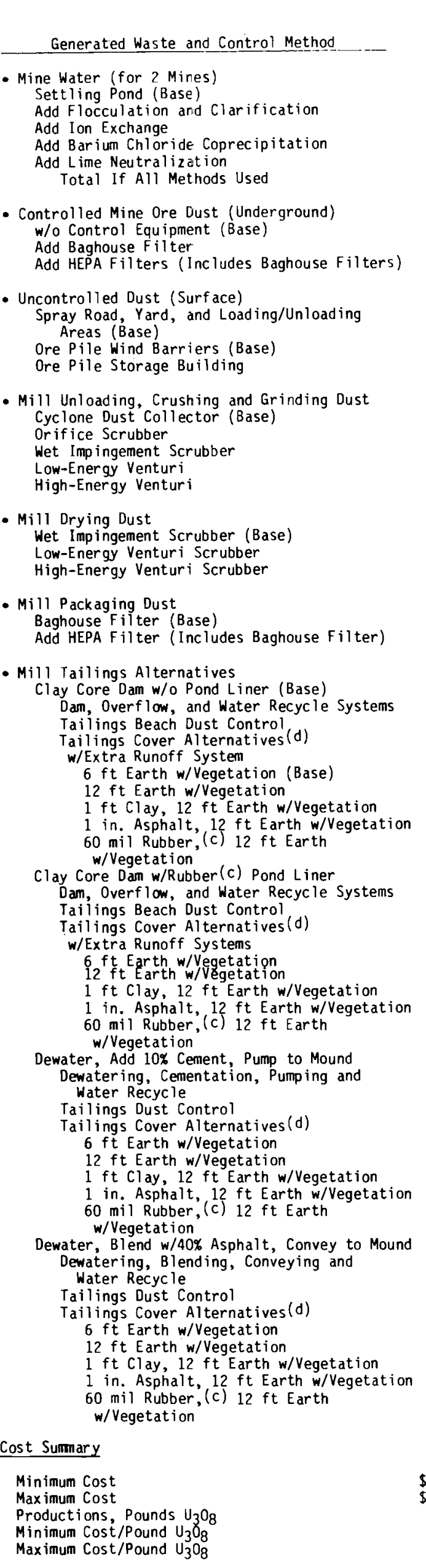

$\frac{\text { Cost Estimates (a) }}{\text { Capital Cost Annual Cost }}$

\begin{tabular}{rr}
$\$ 387,000$ & $\$ 135,000$ \\
585,000 & 231,000 \\
946,000 & 299,000 \\
83,000 & 86,000 \\
282,000 & 184,000 \\
\hline $2,283,000$ &
\end{tabular}

231,000
299,000
86,000

$\frac{184,000}{935,000}$

$\begin{array}{rr}0 & \begin{array}{r}5,058,00 \\ 9,213,000 \\ 27,653,000\end{array} \quad 13,246,000\end{array}$

75,000
150,000
741,000

72,000
44,000

193,000

139,000
278,000
334,000

389,000
473,000

106,000

222,000

298,000
515,000

14,000
16,000 $\quad \begin{array}{r}8,000 \\ 11,000\end{array}$

20,000

8,000
11,000

13,000
18,000

6,000
11,000

$99+\%$ Dust Reduction

$43,546,000$

$22,256,000$

23,000,000(e)

$37,400,000$
39,900

$63,400,000$

$102,000,000$

$108,146,000$

$23,000,000$
37,$400 ; 000$

$39,900,000$

$102,000,000$

$64,125,000$

$9,000,000(\mathrm{e})$

$16,200,000$
$11,250,000$

$17,450,000$
$29,200,000$

$48,500,000$

$186,256,000(\mathrm{e})$

$15,300,000$

$27,540,000$
29,665

$29,6655,000$
$49,640,000$

$82,450,000$

$\$ 67,324,000 \$ 22,851,000$

$$
\begin{array}{r}
1,108,800 \mathrm{lb} \\
\$ 20.61 / 1 \mathrm{~b} \\
\$ 1,308.33 / 1 \mathrm{~b}
\end{array}
$$

30-90\% Solids Settle (S)

99. 96 Dust Reduction
99.998 Dust Reduction

30-95\% Dust Reduction
30-608 Dust Reduction

80-100\% Dust Reduction

978 Dust Reduction

$99+\%$ Dust Reduction
$99+\%$ Dust Reduction

$38,114,000$
0

$224,000(e)$
365,000

389,000
619,000

$180,335,000$

$0-0.08 x$ Seepage $(f)$

$88,000(\mathrm{e})$
158,000
170,000

170,000
285,000
99. $9+\%$ Dust Reduction
$99.99+\%$ Dust Reduction

Reduced by $86 \%$, Radium Reduced $99 \%$

Prec ipitates Heavy Metals, Increases pH, Helps Remove Radium

No Dust Reduction, but wel1 Within Standards

50\% Dust Reduction

-15\% Seepage
igh Rainf all Minimizes Need For Control

$\begin{array}{ll}224,000(\mathrm{e}) & \begin{array}{l}\text { Reduces Radon by Factor of About } 11 \\ 365,000\end{array} \\ \text { Reduces Radon by Factor of About } 60\end{array}$

389,000 Reduces Radon by Factor of About 100

996,000 Reduces Radon by Factor of About 400

0-0.2\% Seepage
High Rainfall Minimizes Need for Control

Reduces Radon by Factor of About 11
Reduces Radon by Factor of About 60

Reduces Radon by Factor of About 60
Reduces Radon by Factor of About 100

Reduces Radon by Factor of About 100
Reduces Radon by Factor of About 400

Reduces Radon by Factor of About 400

Reduces Radon by Factor of About 11

Reduces Radon by Factor of About 60

Reduces Radon by Factor of About 100
Reduces Radon by Factor of About 400

Reduces Radon by Factor of About 400

O-0.06\% Seepage(f)
High Rainfall Minimizes Need for Control

149,000 Reduces Radon by Factor of About 11

Reduces Radon by Factor of About 60

Reduces Radon by Factor of About 100
Reduces Radon by Factor of About 400

Reduces Radon by Factor of About 400
High
High

High
High
High

$\underset{H i g h}{H}$

High
High

High
High
High

High
Medium

High

chnology ience

gh

gh

$\underset{\substack{g h \\ \text { gh }}}{g h}$

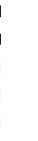

gh

Medium

Medium

Medium

High

Medium

Medium

Medium

Medium

Low

Medium
Medium

Mediun

Medium

Low

Medium

Medium
Medium
Medium

Medium

Notes: (a) Costs could go up to 3 times higher than these for some sites because of variables in site and process characteristics.

(c) Multi-ply Hypalon or equivalent material.

All of these cases should hold radon release to levels close to background. They should also el iminate release of radioactive particulates. Radioactivity levels should be close to background

$12 \mathrm{ft}$ Earth reduces radon emanation by factor of 60 from no cover.

$12 \mathrm{ft}$ Earth reduces radon emanation by factor of 11

(e) Tailings cover capital costs are incurred af ter the mill closes down. A sinking fund is established to pay for the cover. 

TABLE 8.4. Cost and Effectiveness of Environmental Control Technologies at Thomas Caldera Mine and Mi11 (Utah)

\begin{tabular}{|c|c|c|c|c|}
\hline Generated Waste and Control Method & \multicolumn{2}{|c|}{ Cost Estimates $(a)$} & Estimate of Relative Effectiveness ${ }^{(b)}$ & $\begin{array}{l}\text { Tecnnology } \\
\text { Conf idegfe } \\
\text { Level } \\
\end{array}$ \\
\hline $\begin{array}{l}\text { Mine Water } \\
\text { Settling Pond (Base) } \\
\text { Add Flocculation and Clarification } \\
\text { Add Ion Exchange } \\
\text { Add Barium Chloride Coprecipitation } \\
\text { Add Lime Neutralization } \\
\text { Total If All Methods Used }\end{array}$ & $\begin{array}{r}\$ 83,000 \\
180,000 \\
291,000 \\
26,000 \\
87,000 \\
667,000\end{array}$ & $\begin{array}{r}\$ 30,000 \\
68,000 \\
92,000 \\
23,000 \\
32,000 \\
245,000\end{array}$ & $\begin{array}{l}\text { 30-90\% Solids Settle } \\
\text { TSS Reduced } 97 \% \text {, COD Reduced } 86 \% \text {, Radium Reduced } 99 \% \\
\text { Recovers } 92 \% \text { of Uranium } \\
\text { Radium Reduced } 99.9 \% \\
\text { Precipitates Heavy Metals, Increases } \mathrm{pH} \text {, Helps Remove Radium }\end{array}$ & $\begin{array}{l}\text { High } \\
\text { High } \\
\text { High } \\
\text { ligh } \\
\text { tigh }\end{array}$ \\
\hline $\begin{array}{l}\text { - Uncontrolled Dust (Surface) } \\
\text { Spray Road, Yard, and Loading/Unloading Areas } \\
\text { (Base) Wind Barriers (Base) } \\
\text { Ore P Ple Wile Storaile Building } \\
\text { Ore Pile Storage }\end{array}$ & $\begin{array}{r}75,000 \\
150,000 \\
741,000\end{array}$ & $\begin{array}{r}232,000 \\
49,000 \\
192,000\end{array}$ & $\begin{array}{l}\text { 30-95\% Dust Reduction } \\
20-60 \% \text { Dust Reduction } \\
\text { 80-100\% Dust Reduction }\end{array}$ & $\begin{array}{l}\text { tigh } \\
\text { tigh } \\
\text { High }\end{array}$ \\
\hline $\begin{array}{l}\text { - Mill Crushing and Grinding Oust } \\
\text { Cyc lone Oust Collector (Base) } \\
\text { Orif ice Scrubbers } \\
\text { wet Imp Ingement Scrubbers } \\
\text { Low-Energy Venturi Srubbers } \\
\text { High-Energy Ventur I Scrubbers }\end{array}$ & $\begin{array}{l}139,000 \\
278,000 \\
334,000 \\
389,000 \\
473,000\end{array}$ & $\begin{array}{l}106,000 \\
167,000 \\
222,000 \\
298,000 \\
515,000\end{array}$ & $\begin{array}{l}50 \% \text { Dust Reduct ion } \\
94 \% \text { Dust Reduct ion } \\
97 \% \text { Dust Reduct ion } \\
\text { 99+\% Dust Reduct ion } \\
99+\% \text { Dust Reduct ion }\end{array}$ & $\begin{array}{l}\text { High } \\
\text { High } \\
\text { High } \\
\text { High } \\
\text { High }\end{array}$ \\
\hline $\begin{array}{l}\text { - Mill Drying Dust } \\
\text { Wet Impingement Scrubber (Base) } \\
\text { Low-Energy Venturi Scrubber } \\
\text { High-Energy Vent ur I Scrubber }\end{array}$ & $\begin{array}{l}14,000 \\
16,000 \\
20,000\end{array}$ & $\begin{array}{r}8,000 \\
11,000 \\
17,000\end{array}$ & $\begin{array}{l}\text { 97\% Dust Reduction } \\
\text { 99+\% Dust Reduction } \\
99+\% \text { Dust Reduction }\end{array}$ & $\begin{array}{l}\text { High } \\
\text { High } \\
\text { High }\end{array}$ \\
\hline $\begin{array}{l}\text { - Mill Packaging Dust } \\
\text { Baghouse Filter (Base) } \\
\text { Add HEPA Filter (Includes Baghouse Filter) }\end{array}$ & $\begin{array}{l}13,000 \\
18,000\end{array}$ & $\begin{array}{r}6,000 \\
11,000\end{array}$ & $\begin{array}{l}99.9+\% \text { Dust Reduction } \\
99.99+8 \text { Dust Reduction }\end{array}$ & $\begin{array}{l}\text { High } \\
\text { Medium }\end{array}$ \\
\hline \multicolumn{5}{|l|}{ - Mill Tailings Alternatives } \\
\hline \multirow{2}{*}{$\begin{array}{l}\text { Clay Core Dam } w / 3 \mathrm{ft} \text { Clay Pond Liner (Base) } \\
\text { Dam, Liner and Water Recycle System } \\
\text { Tailings Beach Dust Control } \\
\text { Tailings Cover Alternatives (d) } \\
6 \mathrm{ft} \text { Earth w/6 in. Rock (Base) } \\
12 \mathrm{ft} \text { Earth } w / 6 \text { in. Rock } \\
1 \mathrm{ft} \text { Clay, } 12 \mathrm{ft} \text { Earth w/6 in. Rock } \\
1 \mathrm{in} \text {. Asphalt, } 12 \mathrm{ft} \text { Earth w/6 in. Rock } \\
60 \mathrm{mil} \text { Rubber, (c) } 12 \mathrm{ft} \text { Earth } \\
w / 6 \text { in. Rock }\end{array}$} & $\begin{array}{r}46,096,000 \\
163,000\end{array}$ & $\begin{array}{r}23,042,000 \\
296,000\end{array}$ & $\begin{array}{l}\text { 0-3\% Seepage } \\
50-95 \% \text { Effect ive }\end{array}$ & $\begin{array}{l}\text { High } \\
\text { Medium }\end{array}$ \\
\hline & $\begin{array}{l}18,000,000(\mathrm{e}) \\
32,400,000 \\
34,900,000 \\
58,400,000\end{array}$ & $\begin{array}{l}176,000(e) \\
316,000 \\
341,000 \\
570,000\end{array}$ & $\begin{array}{l}\text { Reduces Radon by Factor of About } 11 \\
\text { Reduces Radon by Factor of About } 60 \\
\text { Reduces Radon by Factor of About } 100 \\
\text { Reduces Radon by Factor of About } 400\end{array}$ & $\begin{array}{l}\text { Medium } \\
\text { Medium } \\
\text { Medium } \\
\text { Medium }\end{array}$ \\
\hline \multirow{3}{*}{ 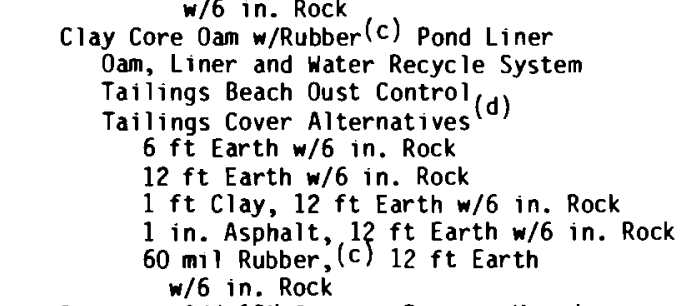 } & $\begin{array}{r}103,696,000 \\
163,000\end{array}$ & $\begin{array}{r}94 /, 000 \\
36,831,000 \\
296,000\end{array}$ & $\begin{array}{l}\text { Reduces Radon by Factor of About } 400 \\
0-0.2 x \text { Seepage } \\
50-95 \% \text { Effective }\end{array}$ & $\begin{array}{l}\text { Medium } \\
\text { High } \\
\text { Medium }\end{array}$ \\
\hline & $\begin{array}{l}18,000,000(e) \\
32,400,000 \\
34,900,000 \\
58,400,000\end{array}$ & $\begin{array}{l}176,000(e) \\
316,000 \\
341,000 \\
570,000\end{array}$ & $\begin{array}{l}\text { Reduces Radon by Factor of About } 11 \\
\text { Reduces Radon by Factor of About } 60 \\
\text { Reduces Radon by Factor of About } 100 \\
\text { Reduces Radon by Factor of About } 400\end{array}$ & $\begin{array}{l}\text { Medium } \\
\text { Med ium } \\
\text { Med ium } \\
\text { Med ium }\end{array}$ \\
\hline & $97,000,000$ & 947,000 & Reduces Radon by Factor of About 400 & Medium \\
\hline $\begin{array}{l}\text { Dewater, Add 10\% Cement, Pump to Mound } \\
\text { Dewatering, Cementation, Pumping and water } \\
\text { Recycle } \\
\text { Tailings Dust Control } \\
\text { Tailings Cover Alternatives } \\
\text { (d) }\end{array}$ & $\begin{array}{r}62,490,000 \\
81,000\end{array}$ & $\begin{array}{r}179,476,000 \\
148,000\end{array}$ & $\begin{array}{l}0-0.08 \% \text { Seepage } \\
\text { 50-95\% Effective }\end{array}$ & $\begin{array}{l}\text { Low } \\
\text { Medium }\end{array}$ \\
\hline $\begin{array}{l}\text { Tailings Cover Alternatives }(\mathrm{d}) \\
6 \mathrm{ft} \text { Earth } w / 6 \text { in. Rock } \\
12 \mathrm{ft} \mathrm{Earth} w / 6 \text { in. Rock } \\
1 \mathrm{ft} \mathrm{clay,} 12 \mathrm{ft} \text { Earth w/6 in. Rock } \\
1 \mathrm{in} \text {. Asphalt, (12) } \mathrm{ft} \text { Earth } \mathrm{w} / 6 \mathrm{in} \text {. Rock } \\
60 \mathrm{mil} \text { Rubber, (c) } 12 \mathrm{ft} \text { Earth w/6 }\end{array}$ & $\begin{array}{l}9,000,000(\mathrm{e}) \\
16,200,000 \\
17,450,000 \\
29,200,000\end{array}$ & $\begin{array}{l}88,000(e) \\
158,000 \\
170,000 \\
285,000\end{array}$ & $\begin{array}{l}\text { Reduces Radon by Factor of About } 11 \\
\text { Reduces Radon by Factor of About } 60 \\
\text { Reduces Radon by Factor of About } 100 \\
\text { Reduces Radon by Factor of About } 400\end{array}$ & $\begin{array}{l}\text { Medium } \\
\text { Medium } \\
\text { Medium } \\
\text { Medium }\end{array}$ \\
\hline $\begin{array}{l}\text { in. Rock } \\
\text { Dewater, Biend } w / 40 \% \text { Asphalt, Convey to Mound } \\
\text { Dewater ing, Blending, Conveying and water }\end{array}$ & $48,500,000$ & 473,000 & Reduces Radon by Factor of About 400 & Medium \\
\hline \multirow{3}{*}{ 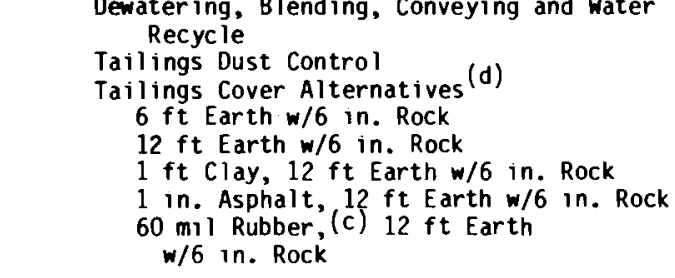 } & $\begin{array}{r}188,090,000 \\
81,000\end{array}$ & $\begin{array}{r}1,487,367,000 \\
148,000\end{array}$ & $\begin{array}{l}0-0.06 \% \text { Seepage }^{(f)} \\
50-95 \% \text { Effective }\end{array}$ & $\begin{array}{l}\text { Low } \\
\text { Medium }\end{array}$ \\
\hline & $\begin{array}{l}15,300,000(\mathrm{e}) \\
27,540,000 \\
29,665,000 \\
49,640,000\end{array}$ & $\begin{array}{l}149,000(\mathrm{e}) \\
269,000 \\
290,000 \\
484,000\end{array}$ & $\begin{array}{l}\text { Reduces Radon by Factor of about } 11 \\
\text { Reduces Radon by Factor of about } 60 \\
\text { Reduces Radon by Factor of about } 100 \\
\text { Reduces Radon by Factor of about } 400\end{array}$ & $\begin{array}{l}\text { Medium } \\
\text { Medium } \\
\text { Medium } \\
\text { Medium }\end{array}$ \\
\hline & $82,450,000$ & 805,000 & Reduces Radon by Factor of about 400 & Medium \\
\hline \multicolumn{5}{|l|}{ Cost Surmary } \\
\hline $\begin{array}{l}\text { Minimum Cost } \\
\text { Maximum Cost } \\
\text { Production, Pounds } U_{308} \\
\text { Minimum Cost/Pound } U_{308} \\
\text { Maximum Cost/Pound } U_{308}\end{array}$ & \multicolumn{3}{|c|}{$\begin{array}{r}\$ 64,733,000 \$ 23,945,000 \\
\$ 272,615,000 \$ 1,489,532,000 \\
1,108,8001 \mathrm{lbs} \\
\$ 121.60 / 1 \mathrm{~b} \\
\$ 1,343.37 / 1 \mathrm{~b}\end{array}$} & \\
\hline
\end{tabular}

Notes: (a) Costs could go up to 3 t imes higher than these for some sites because of variables in site and process characteristics.

(c) Multi-ply Hypalon or equivalent material.

All of these cases should hold radon release to levels close to background. They should also eliminate release of radioactive particulates. Radioactivity levels should be close to background.

$6 \mathrm{ft}$ Earth reduces radon emanation by factor of 11 from no cover.

1 in. Asphalt equivalent to $60 \mathrm{ft}$ of earth cover.

(e) Tailings cover capital costs are incurred after the mill closes down. A sinking fund is established to pay for the cover.
(f) Includes an allowance for water storage pond leakage also. 

TABLE 8.5. Cost and Effectiveness of Environmental Control Technologies at the Florida Phosphate Mine and Mi11 (Florida)

\begin{tabular}{|c|c|c|c|c|}
\hline Generated Waste and Control Method & \multicolumn{2}{|c|}{ Cost Estimates $^{(a)}$} & Estimate of Relative Effectiveness(b) & $\begin{array}{l}\text { Technology } \\
\text { Confidence } \\
\text { Level (b) } \\
\end{array}$ \\
\hline $\begin{array}{l}\text { - Mine Effluents } \\
\text { Mine Water and Dust Control (None Required) }\end{array}$ & $0 s$ & $\$$ & Mine water Used in Mill and No Dust is Generated & .. \\
\hline $\begin{array}{l}\text { - Mill Drying Dust } \\
\text { Wet Impingement Scrubber (Base) } \\
\text { Low-Energy Venturi Scrubber } \\
\text { High-Energy Venturi Scrubber }\end{array}$ & $\begin{array}{r}8,000 \\
9,000 \\
11,000\end{array}$ & $\begin{array}{l}5,000 \\
5,000 \\
9,000\end{array}$ & $\begin{array}{l}97 \% \text { Dust Reduction } \\
99+\% \text { Dust Reduction } \\
99+\% \text { Dust Reduction }\end{array}$ & $\begin{array}{l}\text { High } \\
\text { High } \\
\text { High }\end{array}$ \\
\hline $\begin{array}{l}\text { - Mill Packaging Dust } \\
\text { Baghouse Filter (Base) } \\
\text { Add HEPA Filter (Includes Baghouse filter) }\end{array}$ & $\begin{array}{l}13,000 \\
18,000\end{array}$ & $\begin{array}{r}6,000 \\
11,000\end{array}$ & $\begin{array}{l}99.9+\% \text { Dust Reduction } \\
99.99+\% \text { Oust Reduction }\end{array}$ & $\begin{array}{l}\text { High } \\
\text { Medium }\end{array}$ \\
\hline $\begin{array}{l}\text { - Mill Tailings Alternatives } \\
\text { Base Case - } 3 \text { Separate Streams } \\
\text { Crushing and Grinding Tailings, ( }(\$ 1 \text { lmes) } \\
\text { Initial Slimes Pond, Liner, and Cover } \\
\text { Pump, Plpe, Recycle and Distribution } \\
\text { Systems }\end{array}$ & $\begin{array}{l}1,054,000 \\
2,585,000\end{array}$ & $1,206,0000^{(d)}$ & $\begin{array}{l}0-0.2 \% \text { Seepage } \\
\text { Seepage Uncertain, But Less Radioactive Than For } \\
\text { Phosphate Mill }\end{array}$ & $\begin{array}{l}\text { High } \\
\text { High }\end{array}$ \\
\hline $\begin{array}{l}\text { Digestion and Filtrat ion Tailings (Gypsum) } \\
\text { Pump, Pipe, Recycle and Distribution } \\
\text { Systems } \\
\text { Extraction, Stripping, Prec. \& Thick. } \\
\text { Tailings (Phosphates) } \\
\text { Pump, Pipes, Lined (c) and Ponds } \\
\text { Hater Recycle }\end{array}$ & $7,209,000$ & $2,216,000$ & $\begin{array}{l}\text { Seepage Uncertain, But Less Radioactive Than For } \\
\text { Phosphate Mill }\end{array}$ & High \\
\hline $\begin{array}{l}\text { Tailings Cover Alternatives ( } \\
6 \mathrm{ft} \text { Earth w/Vegetation (Base) } \\
12 \mathrm{ft} \text { Earth } w / / \text { legetation } \\
1 \mathrm{ft} \mathrm{Clay,} 12 \mathrm{ft} \text { Earth } \mathrm{w} / \text { Vegetation }\end{array}$ & $\begin{array}{l}1,080,000{ }^{(f)} \\
1,944,000 \\
2,172,000\end{array}$ & $\begin{array}{l}11,000^{(f)} \\
19,000 \\
21,000\end{array}$ & $\begin{array}{l}\text { Reduces Radon by Factor of About } 11 \\
\text { Reduces Radon by Factor of About } 60 \\
\text { Reduces Radon by Factor of About } 100\end{array}$ & $\begin{array}{l}\text { Medium } \\
\text { Medium } \\
\text { Medium }\end{array}$ \\
\hline $\begin{array}{l}\text { 1n. Asphait, } 12 \mathrm{ft} \text { Earth } \\
\text { W/Vegetation } \\
60 \mathrm{mil} \text { Rubber, (c) } 12 \mathrm{ft} \text { Earth }\end{array}$ & $3,504,000$ & 34,000 & Reduces Radon by Factor of About 400 & Medium \\
\hline \multicolumn{5}{|c|}{$\begin{array}{l}\text { Dewater, Add 10\% Cement, Pump to Mound (1 Stream) } \\
\text { Dewatering, Cementation, Pump ing and }\end{array}$} \\
\hline $\begin{array}{l}\text { Dewatering, Cementation, Pumping and } \\
\text { Water Recycle } \\
\text { Tailings Cover Alternatives }\end{array}$ & $38,626,000$ & $65,656,000$ & $0-0.08 \%$ Seepage $\mathrm{e}^{(g)}$ & Low \\
\hline $\begin{array}{l}6 \mathrm{ft} \text { Earth w/Vegetation } \\
12 \mathrm{ft} \text { Earth w/vegetation } \\
1 \mathrm{ft} \text { Clay, } 12 \mathrm{ft} \text { Earth } \mathrm{w} / \text { Vegetation } \\
1 \text { in. Asphalt, } 12 \mathrm{ft} \text { Earth w/Vegetation } \\
60 \mathrm{mil} \text { Rubber, (c) } 12 \mathrm{ft} \text { Earth }\end{array}$ & $\begin{array}{l}5,760,000(\mathrm{f}) \\
10,368,000 \\
11,584,000 \\
18,688,000\end{array}$ & $\begin{array}{l}56,000 \\
101,000 \\
113,000 \\
182,000\end{array}$ & $\begin{array}{l}\text { Reduces Radon by Factor of About } 11 \\
\text { Reduces Radon by Factor of About } 60 \\
\text { Reduces Radon by Factor of About } 100 \\
\text { Reduces Radon by Factor of About } 400\end{array}$ & $\begin{array}{l}\text { Medium } \\
\text { Medium } \\
\text { Medium } \\
\text { Medium }\end{array}$ \\
\hline \multirow{4}{*}{$\begin{array}{l}\text { Dewater, Blend w/40\% Asphalt, Convey to Mound } \\
\text { Dewatering, Blending, Conveying and } \\
\text { Water Recycle } \\
\text { Tailings Cover Alternatives (e) } \\
6 \mathrm{ft} \text { Earth w/Vegetation } \\
12 \mathrm{ft} \text { Earth w/Vegetati on } \\
1 \mathrm{ft} \text { Clay, } 12 \mathrm{ft} \text { Earth w/Vegetation } \\
1 \mathrm{in} \text {. Asphalt, (1) ft Earth w/Vegetation } \\
60 \mathrm{mil} \text { Rubber, (c) 12 ft Earth } \\
\text { w/Vegetation }\end{array}$} & $31,040,000$ & 303,000 & Reduces Radon by Factor of About 400 & Medium \\
\hline & $104,205,000$ & $506,791,000$ & $0.06 \%$ Seepage $^{(g)}$ & Low \\
\hline & $\begin{array}{l}9,000,000(f) \\
16,200,000 \\
18,100,000 \\
29,200,000\end{array}$ & $\begin{array}{l}88,000 \\
158,000 \\
177,000 \\
285,000\end{array}$ & $\begin{array}{l}\text { Reduces Radon by Factor of About } 11 \\
\text { Reduces Radon by Factor of About } 60 \\
\text { Reduces Radon by Factor of About } 100 \\
\text { Reduces Radon by Factor of About } 400\end{array}$ & $\begin{array}{l}\text { Medium } \\
\text { Medium } \\
\text { Medium } \\
\text { Medium }\end{array}$ \\
\hline & $48,500,000$ & 473,000 & Reduces Radon by Factor of About 400 & Medium \\
\hline \multicolumn{5}{|l|}{ Cost Summary } \\
\hline $\begin{array}{l}\text { Minimum Cost } \\
\text { Maximum Cost } \\
\text { Production, Pounds } U_{308} \\
\text { Minimum Cost/Pound } U_{308} \\
\text { Maximum Cost/Pound } U_{308}\end{array}$ & $\$ 13,071,000$ & $\begin{array}{r}\$ 4,054,000 \\
\$ 506,899,000 \\
377,300 \mathrm{Ibs} \\
\$ 10.74 / 1 \mathrm{~b} \\
\$ 1,343.49 / 1 \mathrm{~b}\end{array}$ & & \\
\hline
\end{tabular}

Notes: (a) Costs could go up to 3 times higher than these for some sites because of variables in site and process characteristics.

b) These are the best est imates based upon the literature reviewed.

(c) Multi-ply Hypalon or equivalent material.

d) Pond is used during first 6 months of operation only. Capital and first year operating costs are prorated by capital recovery over 20-year

(e) All of these cases should hold radon release to levels close to background. They should also el iminate release of radioactive particulates. Radioactivity levels should be close to background

Assumptions: $6 \mathrm{ft}$ Earth reduces radon emanation by factor of 11 from no cover.

$12 \mathrm{ft}$ Earth reduces radon emanation by factor of 60 from no cover.

1 in. Asphalt equivalent to $60 \mathrm{ft}$ of earth cover.
$50 \mathrm{mil}$ rubber is equivalent to 1 in. asphalt.

(f) Tailings cover capital costs are incurred after the mill closes down. A sinking fund is established to pay for the cover.
(g) Includes an allowance for water storage pond leakage al so. 

The importance of water conservation necessitates the use of liners for the tailings pond in even the base case. The base environmental control costs are slightly higher than at Bokan Mountain because the pond liners are required.

Table 8.5 summarizes the estimates of cost and effectiveness of environmental control at the Florida phosphate resource. The grade of ore averages abut $0.0065 \% \mathrm{U}_{3} \mathrm{O}_{8}$ (same as Chattanooga shale). The mine 15 open pit and it utilizes a dragline and dredge system. The bulk of the materials handling and processing is performed wet and rainfall is abundant, so little dust is generated. The tailings are the main concern. The phosphate tailings are separated and stored for later processing (in base case only). Processing the phosphate would substantially reduce the environmental control costs charged to uranium production.

In the 4 tables discussed, it is apparent that the cost $(>\$ 1,000 / 1 b$ uranium) of combining tailings with cement or asphalt is too high for consideration when processing the low grade uranium ores. Low grade ore tailings should not require as stringent control as the higher grade ore $(>0.1 \%)$ currently in production. Cost can be reduced if less stringent controls (e.g., thinner tailings covers) are used. Studies should be performed to determine more precisely what degree of environmental control is required as a minimum.

The effectiveness of the technologies used in this study have the potential of holding offsite discharge of effluents to very low levels. As can be observed from the tables, the more effective technologies usually cost more. An example of how costs rise with effectiveness is shown in Figure 8.1, which represents the methods for controlling dust from unloading, crushing, and grinding the ore a mill requiring 30,000-cfm air flow.

\subsection{COST ESTIMATES FOR ENVIRONMENTAL CONTROL TECHNOLOGIES}

The cost estimates for all of the uranium mone sites are summarized in Tables 8.2, 8.3, 8.4 and 8.5. The base year for all estimates is 1978. The capital costs include the total installation costs. The constituent factors used are itemized in Section 8.1.1. The annual costs include all of the 


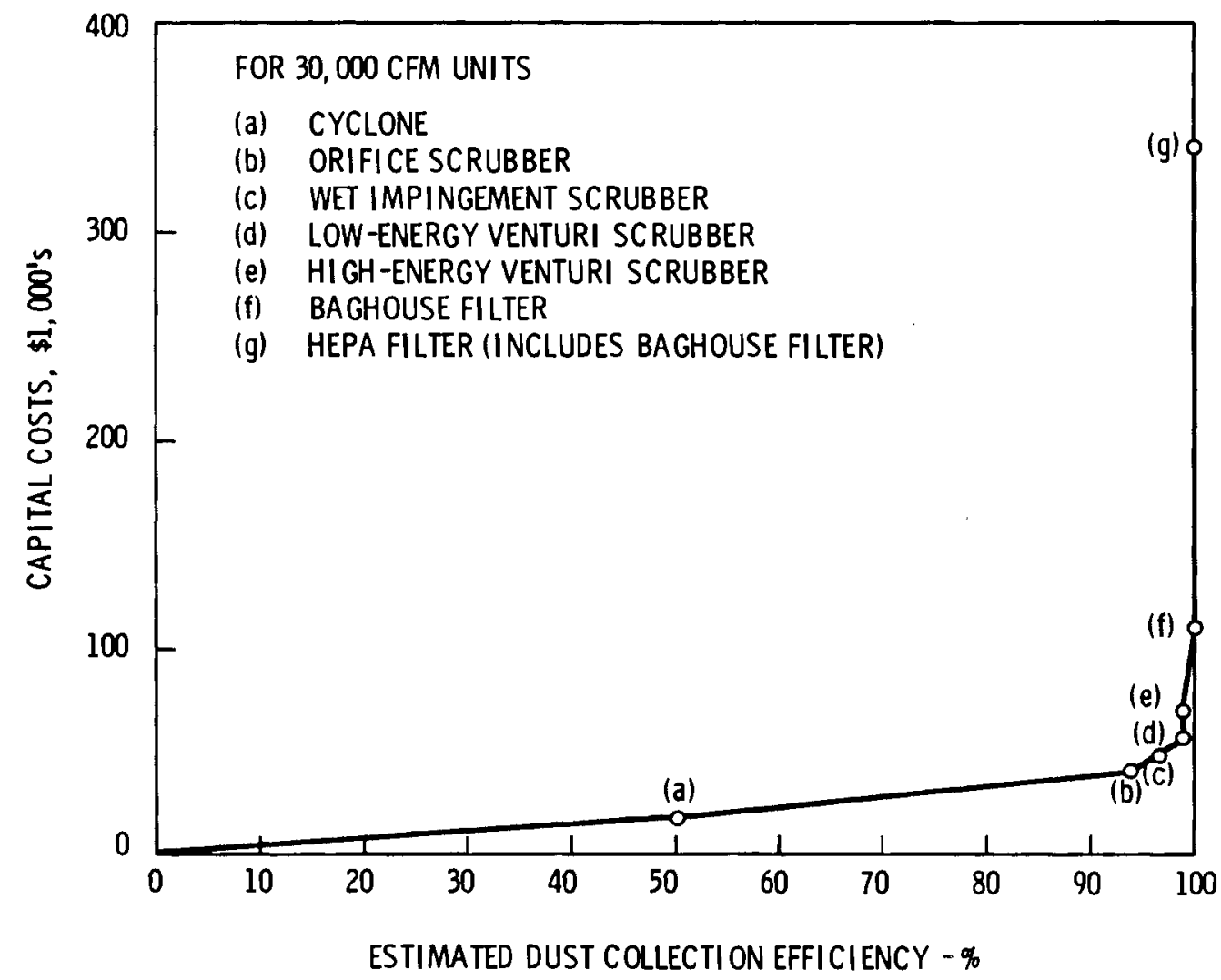

FIGURE 8.1. Mill Unloading, Crushing, and Grinding Dust Collection Capital Costs as a Function of Efficiency

operating costs (Section 8.1.2), allowances for annual depreciable fixed charges (Section 8.1.3), and a fixed charge for land and working capital (Section 8.1.4).

\subsubsection{Capital Installation Cost}

The capital cost of installing the equipment in this report is comprised of the following elements:

Direct Costs

Purchased Equipment - Deliver
Equipment Installation
Instrumentation and Controls
Piping (Installed)

$\underline{\text { Factor }}(\%)^{(\mathrm{a})}$

100

41

13

31 
Electrical (Installed)

Total Direct Plant Cost

Indirect Costs

Engineering and Supervision
Construction Expenses
Total Indirect Plant Cost
Contractor's Fee (5\% of DPC \& IPC)
Contingency ( $10 \%$ of DPC \& IPC)
Total Capital Installation Cost
(a) Based on the values in Reference 3 and
rounded off for calculation.

10

195

32

34

66

13

26

300

The land required for a specific facility (e.g., tailings pond) is costed out at the purchase price and is included in the cost estimate. The cost of installing the items that contain no equipment (e.g., settling pond) include the costs of construction plus $20 \%$ for project costs.

\subsubsection{Operating Costs}

The operating costs include the costs of operating labor, maintenance, materials, power, and miscellaneous items. The cost of the operating labor includes these constituents:

\begin{tabular}{lr} 
Labor & $\$ 8.70 / \mathrm{hr}$ \\
Direct Supervision and Clerical (15\% of Labor) & $1.31 / \mathrm{hr}$ \\
Laboratory Charges (15\% of Labor) & $1.31 / \mathrm{hr}$ \\
Plant Overhead & $7.05 / \mathrm{hr}$ \\
Administration Overhead & $1.76 / \mathrm{hr}$ \\
\hline Total Operating Labor Cost & $\$ 20.13 / \mathrm{hr}$
\end{tabular}


The maintenance costs were usually taken as a flat percentage ( $1 \%$ to $6 \%$ ) of the capital installation cost. Whenever possible, the man hours were estimated and costed out at $\$ 20.13 / \mathrm{hr}$, which included an allowance for replacement parts. In cases where major maintenance replacement components were required, the costs were itemized separately (e.g., filter bags for baghouses). The major materials routinely consumed in the environmental control process were also itemized and costed separately, (e.g., lime, cement, asphalt, etc.). Power çansumption was estimated in terms of kilowatt hours and it was costed out at $\$ 0.03 / \mathrm{kWh}$. The miscellaneous category included contingency and other items (e.g., special supplies, parts, etc.) that were inexpensive and general in nature.

\subsubsection{Equivalent Annual Charge for Depreciable Capital Investment}

A fixed rate was applied to convert a depreciable capital investment into an equivalent annual revenue requirement. Rather than calculate a year-byyear cash flow, a single fixed charge rate is assumed to apply over the life of the facility. The fixed charge rate includes provisions for capital recovery, bond interest, return on equity, federal income tax, state income tax, property tax, and property insurance. The fixed charge rate was calculated for the facility assuming financial conditions typical for a uranium mining company. For such a company, the data in Table 8.6 were assumed.

\section{TABLE 8.6. Depreciable Capital Investment}

(\%)

Capitalization
Debt
Equity
Bond Interest Rate
Return on Equity
Federal Income Tax
State Income Tax
Property Tax
Property Insurance
Mine/Mil I Life
Depreciation

24
76
8
15
48
7

2.5 of Capital Cost

0.5 of Capital Cost

Site Dependent

Sum-of-the-Year's-

Digits Method 
When the factors assumed in Table 8.6 were used, the annual capital charge rate was calculated to be 0.2338 for a facility life of 20 years. The rate was simply multiplied by the capital installation cost to give the annual charge for depreciable capital.

\subsubsection{Equivalent Annual Charge for Nondepreciable Capital Investment}

The fixed charge described in Section 8.1.3 does not apply to nondepreciable assets, which include land and working capital. In this study, it was assumed that a cost equivalent to $5 \%$ of the depreciable investment would represent the annual land and working capital charge. This cost rate was used because the charge is minor, and it simplified the many calculations performed in this study.

\subsubsection{Annual Cost}

The annual cost is the sum of the operating cost, the annual depreciable charge, and the annual nondepreciable charge. This cost provides the economic comparision between methods for total costs on an annual basis.

\subsection{EFFECTIVENESS ESTIMATES FOR ENVIRONMENTAL CONTROL TECHNOLOGIES}

The effectiveness of the various environmental control technologies can vary considerably between sites. Like the costs for control, the effectiveness estimates are order-of-magnitude-type approximations. The effectiveness estimates for all of the uranium mine and mill sites are summarized in Tables 8.2, 8.3, and 8.4, and 8.5.

\subsubsection{Control of Airborne Dust from Production Equipment}

To control the dust effluents from mine ventilation, loading, crushing, grinding, by-product recovery, drying, ignition, and packaging-type operations, the list of equipment in Table 8.7 was assumed. The list provides a guide for a preliminary relative comparison of the equipment's dust collection efficiency only. The actual efficiencies of the equipment are likely to be lower because the dust grain loadings of exhaust air assumed in this study are lower than needed for the equipment to perform optimally. 
TABLE 8.7. Dust Collector Efficiency Estimates (3)

\section{Type of Equipment}

Cyclone

Orifice Scrubber

Wet Impingement Scrubber

Low-Energy Venturi Scrubber

High-Energy Venturi Scrubber

Baghouse Filter

HEPA Filter
Collection Efficiency (\%)

\begin{tabular}{cc}
\hline 5 Micron Particles $(a)$ & 1 Micron Particle \\
50 & -- \\
94 & 50 \\
97 & 80 \\
$99+$ & 96 \\
$99+$ & 98 \\
$99.9+$ & $99+$ \\
$99.99+$ & $99.97+$
\end{tabular}

(a) This study assumed the nominal particle size for dust was 5 microns.

\subsubsection{Control of Airborne Dust From Roads and Yards}

Road and yard dust can be controlled by suppressing the dust with moisture or chemicals. The frequency and amount of spraying depends on the weather, amount of usage, type of dust, type of surface, etc. If rigidly administered, the dust in these areas should be controlled with close to $100 \%$ effectiveness although costs may become prohibitive.

\subsubsection{Control of Airborne Dust From Ore Storage Piles}

The primary method of protecting the ore storage piles from wind erosion is to erect prevailing wind barriers or store the ore in buildings. With some types of ore and localities, it may be satisfactory to keep the ore tied down with water spray or to use the spray in conjunction with barriers. It was assumed in this study that a two-sided barrier located on the side of the most prevailing winds would be $20 \%$ to $60 \%$ effective in reducing dust. If supplementary spraying were used, a greater than $60 \%$ dust reduction is possible. The dampness would also reduce the release of dust from subsequent handling operations. The use of a full-scale building is estimated to be 80 to $100 \%$ effective in holding down the dust. However, when high-grade ore (e.g., >0.1\% $U$ ) is used, the building would need some ventilation to maintain low radon levels. 


\subsubsection{Control of Airborne Dust From Tailings Beaches}

In this study, plenty of water was available (except in the Thomas Caldera deposit of Utah) to maintain a water cover over the tailings. This appreciably reduces the amount of dust released from the tailings ponds and is up to $99+\%$ effective. The remaining particles that wash up onto the beach can be periodically sprayed to tie them down or washed back into the pond. If treatments are administered at the right times, up to $95 \%$ of dust released from this source will be eliminated; however, the costs may become prohibitive as $100 \%$ effectiveness is approached.

\subsubsection{Mine Water Control}

The effectiveness estimates for mine water control were taken from uranium mine data. (1) The estimates are as follows:

\section{Method}

Settling Pond

Add Flocculation and Clarification

Add Ion Exchanger

Add Barium Chloride Coprecipitation

Add Lime Neutralization

\section{Effectiveness}

30 to $90 \%$ of solids will settle out.

Total solids in solution are reduced by $97 \%$, chemical oxygen demand is reduced by $86 \%$, and radium content is reduced by up to $99 \%$.

Recovers up to $92 \%$ of uranium.

Radium is reduced up to $99.9 \%$.

Precipitates heavy metals, increases $\mathrm{pH}$, and helps remove up to $90 \%$ of radium.

\subsubsection{Control of Tailings Pond Seepage}

The effectiveness of various methods of depositing the tailings to control seepage are estimated in Table 8.8. The base technology in this study is the use of a clay-core dam for a tailings pond in lieu of the more traditional dams constructed out of tailings. This should reduce seepage by up to a factor of five. The effectiveness of adding a 3-ft clay liner to the pond bottom should reduce seepage by another factor of 5 to 10 . All of the remaining 
TABLE 8.8. Estimated Effectiveness of Various Methods of Seepage Control

Method

Clay-core dam without a lining (base)

Clay-core dam with a 3-ft clay liner

Clay-core dam with a 2-in. asphalt liner

Clay-core dam with a 60-mil rubber(a) liner

Dewater tailings and convey to clay-lined

landf $i 11$

Dewater tailings, blend with $10 \%$ cement, and pump to a clay-lined landfill

Dewater tailings, blend with $40 \%$ asphalt, and truck to an unlined landfill
Effectiveness

0 to $15 \%$ Seepage

0 to $3 \%$ Seepage

0 to $1 \%$ Seepage

0 to $0.2 \%$ Seepage

0 to $0.10 \%$ Seepage $^{(b)}$

0 to $0.08 \%$ Seepage $^{(b)}$

0 to $0.06 \%$ Seepage $^{(b)}$

(a) Multi-ply Hypalon or equivalent.

(b) Includes allowance for rubber-lined recycle water storage pond also. However, this pond will not contain as large an amount of radionuclides and it will be spread over a smaller area.

methods should essentially reduce seepage to zero, providing the liners are protected from breach by climatic effects, rodents, vehicular and animal traffic, etc. (The figures for effectiveness are best engineering judgements based upon very little available data and represent relative approximations on ly.)

\subsubsection{Tailings Covers (at Decommissioning)}

It will be necessary to cover the tailings on mounds, in landfill pits or evaporated tailings ponds to suppress radioactive dust, reduce radioactivity levels at the surface, and reduce the emanation of radon gas to the atmosphere.

The effectiveness of earth, clay, and other covers will vary from site-tosite. Past studies $(2,5)$ of uranium tailings covers estimated the relative effectiveness of various materials for the cover as: 


\begin{tabular}{lc}
\multicolumn{1}{c}{ Cover } & $\begin{array}{c}\text { Fraction of } \\
\text { Radon Emitted }\end{array}$ \\
\cline { 1 - 1 } No Cover (Base) & 1 \\
$1 \mathrm{ft}$ of Earth & 0.7 \\
$6 \mathrm{ft}$ of Earth & 0.09 \\
$10 \mathrm{ft}$ of Earth & 0.02 \\
$60 \mathrm{ft}$ of Earth & 0.003 \\
$1 \mathrm{in.} \mathrm{of} \mathrm{Asphalt}$ & 0.003 \\
$60 \mathrm{mil}$ of Rubber & 0.003 \\
(Hypalon or Equiv.) & \\
\hline & \\
\hline (a) Based upon 222Ra data for uranium \\
tailings.
\end{tabular}

\subsection{REFERENCES}

1. Environmental Protection Agency. 1975. Group II, Development Document for Inter im Final and Proposed Effluent Limitation Guidelines and New Source Performance Standards for the Ore Mining and Dressing Industry, EPA 440/1-75061, U.S. Environmental Protection Agency, Washington, DC.

2. Sears, M. G. et al. 1975. Correlation of Radioactive Waste Treatment Costs and the Environmental Impact of Waste Effluents in the Nuclear Fuel Cycle for Use in Establishing "As Low as Practicable" Guides - Milling of Uranium Ores, ORNL-TM-4903, Vol. 1, Oak Ridge National Laboratory, Oak Ridge, Tennessee.

3. Liptak, B. G. 1974. Environmental Engineers Handbook: Air Pollution, Vol. 2, Chilton Book Company, Radnor, Pennsylvania.

4. Engineering-Science, Inc. 1973. Field Surveillance and Enforcement Guide for Primary Metallurgical Industries, PB-230, 898, prepared for Environmental Protection Agency by Engineering-Science, Inc., McLean, Virginia.

5. U.S. Nuclear Regulatory Commission. 1977. Operation of Bear Creek Project Rocky Mountain Energy Company, Docket No. 40-8452, PB-267 375, National Technical Information Service, Springfield, Virginia. 

APPENDIX A

RADIOLOGICAL DATA 


\section{$\underline{\text { RADIOLOGICAL DATA }}^{(\mathrm{a})}$}

\section{A.1 SPECIFIC ACTIVITIES}

The specific activities of ${ }^{238} U$, and ${ }^{235} U$ can be calculated on a Ci/lb basis as follows:

$$
\text { Specific Activity }=S A=\lambda N
$$

where:

$$
\begin{aligned}
\lambda & =\text { the decay constant for a particular radioactive element } \\
N & =\text { number of atoms per gram } \\
\lambda & =0.693 / T_{1 / 2} \\
T_{1 / 2} & =\text { the half }-1 \text { ife of the element in seconds. }
\end{aligned}
$$

Therefore:

$$
\mathrm{SA}=\frac{(0.693) \mathrm{N}}{\mathrm{T}_{1 / 2}}=\text { discharge } / \mathrm{sec} / \mathrm{g}
$$

or:

$$
S A=\frac{(0.693) N}{T_{1 / 2}\left(3.7 \times 10^{10}\right)}=\frac{\left(1.87297 \times 10^{-11}\right) \mathrm{N}}{T_{1 / 2}}=\mathrm{Ci} / \mathrm{g}
$$

For ${ }^{238} \mathrm{U}$ the following specific activity can be derived:

$$
\begin{aligned}
& S A=\frac{\left(1.87297 \times 10^{-11}\right)(454 \mathrm{~g} / 1 \mathrm{~b})\left(0.6023 \times 10^{24} \mathrm{atom} / \mathrm{mole}\right)}{(238.0508 \mathrm{~g} / \mathrm{mole})\left(4.51 \times \times^{9} 10 \mathrm{yr}\right)(3.1536 \times 10 \mathrm{sec} / \mathrm{yr})} \\
& S A=1.51268 \times 10^{-4} \mathrm{Ci} / \mathrm{lb}
\end{aligned}
$$

(a) Excess significant figures are shown for some numbers and were used for computational purposes only. 
For ${ }^{235} \mathrm{U}$ :

$$
S A=9.731646 \times 10^{-4} \mathrm{Ci} / 1 \mathrm{~b}
$$

The ${ }^{238} U$ decay series is composed of 13 daughter products, as shown in Figure A.1. These 13 products have approximately 13 times the activity of ${ }^{238} U$ itself. Thus, when given the specific activity of ${ }^{238} U$, we can estimate the total specific activity as being 14 times as much. This was done for uranium in Appendices $B$ and $C$.

Figure A.2 shows the decay series for ${ }^{235} \mathrm{U}$. As shown, there are ten ${ }^{235} \mathrm{U}$ daughters. As with ${ }^{238} \mathrm{U}$, the daughter products contribute 10 times the specific activity of ${ }^{235} \mathrm{U}$.

\section{A.2 MAXIMUM PERMISSIBLE CONCENTRATION (MPC) AND RELATIVE RADIOTOXICITY}

Data for this section are taken from the CRC Handbook of Radioactive Nuclides. (1) The MPC standards used in this reference are based on Appendix $B$ of 10 CFR 20. Pertinent isotopes and their MPCs in air and water are shown in Table A.1. The MPCs shown are the limiting average concentrations in air and water that an employee may be exposed to for $40 \mathrm{hr} / \mathrm{wk}$ during a lifetime of employment. As seen for air, soluble ${ }^{238} \mathrm{U}$ and natural uranium have an MPC level of $7 \times 10^{-11} \mathrm{Ci} / \mathrm{ml}$. The MPC standards used to evaluate the environmental control technologies were for ${ }^{238} \mathrm{U}$ MPCs.

\section{A.3. REFERENCES}

1. Wang, Y. ed. 1969. Handbook of Radioactive Nuclides, The Chemical Rubber Company, Cleve Tand, Ohio. 


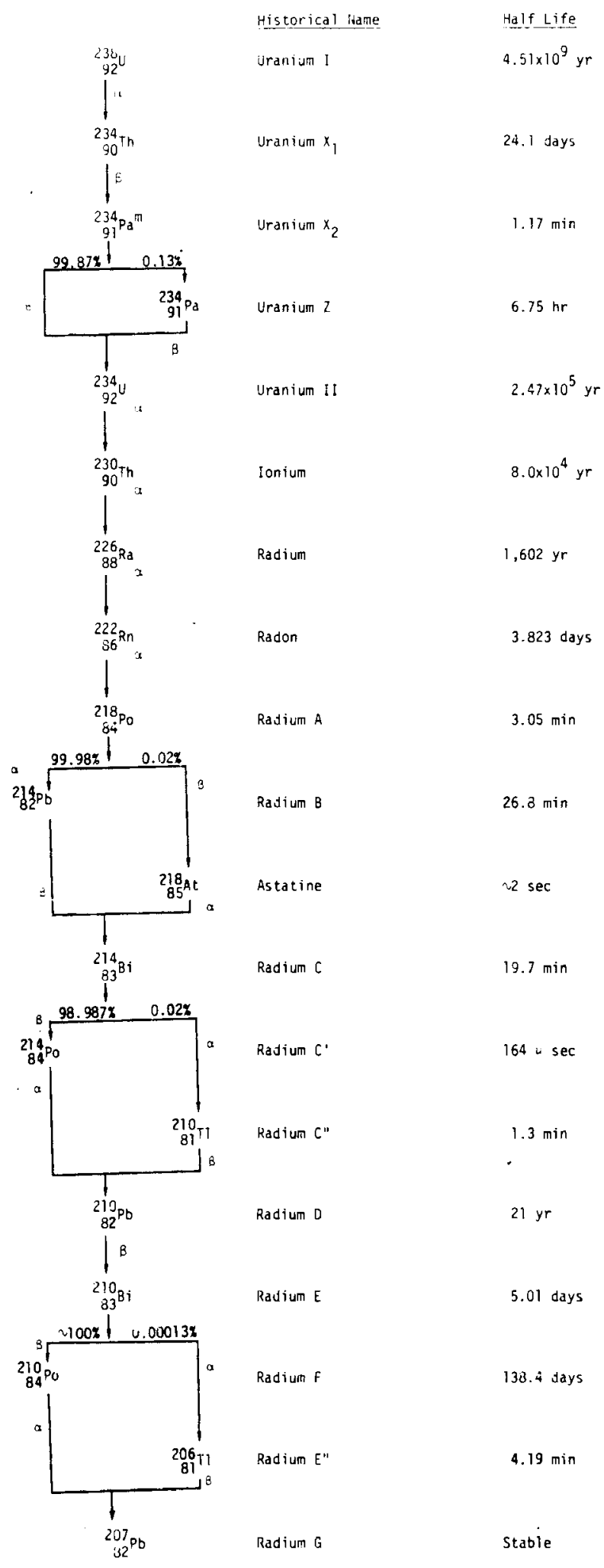

FIGURE A.1. ${ }^{238}$ U Decay Series

A. 3 


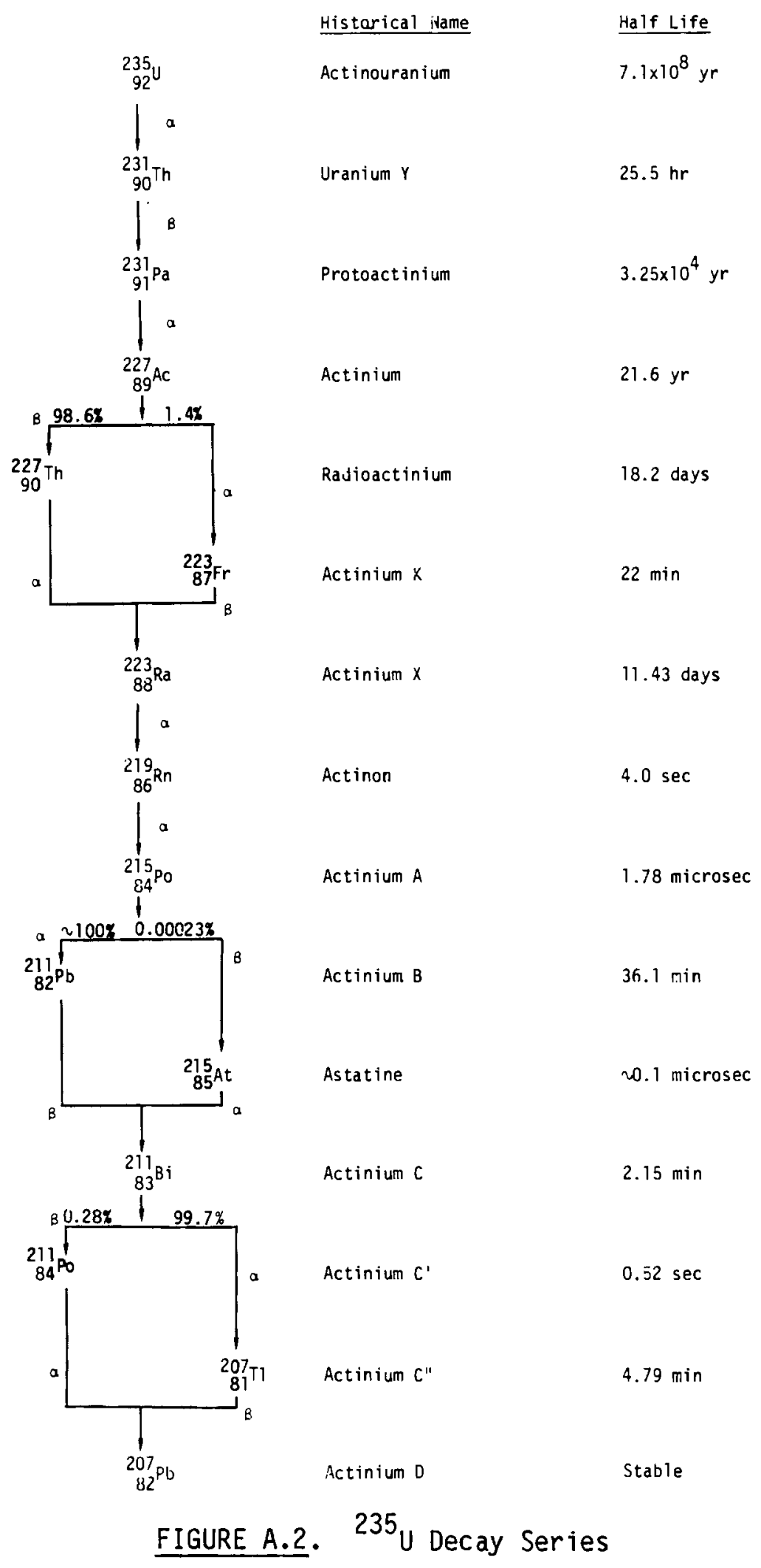

A. 4 
TABLE A.1. Maximum Permissible Concentration of Radionuclides in Air and Water

\begin{tabular}{|c|c|c|c|}
\hline \multicolumn{2}{|c|}{ Isotope } & MPC in Air, $\mu \mathrm{Ci} / \mathrm{ml}$ & MPC in Water, $\mu \mathrm{Ci} / \mathrm{ml}$ \\
\hline $238 U$ & $\begin{array}{l}\text { Soluble } \\
\text { Insoluble }\end{array}$ & $\begin{array}{l}7 \times 10^{-11} \\
1 \times 10^{-10}\end{array}$ & $\begin{array}{l}1 \times 10^{-3} \\
1 \times 10^{-3}\end{array}$ \\
\hline $235 u$ & $\begin{array}{l}\text { Soluble } \\
\text { Insoluble }\end{array}$ & $\begin{array}{l}5 \times 10^{-10} \\
1 \times 10^{-10}\end{array}$ & $\begin{array}{l}8 \times 10^{-4} \\
8 \times 10^{-4}\end{array}$ \\
\hline Natural Uranium & $\begin{array}{l}\text { Soluble } \\
\text { Insoluble }\end{array}$ & $\begin{array}{l}7 \times 10^{-11} \\
6 \times 10^{-11}\end{array}$ & $\begin{array}{l}5 \times 10^{-4} \\
5 \times 10^{-4}\end{array}$ \\
\hline $230 \mathrm{Th}$ & $\begin{array}{l}\text { Soluble } \\
\text { Insoluble }\end{array}$ & $\begin{array}{l}2 \times 10^{-12} \\
1 \times 10^{-11}\end{array}$ & $\begin{array}{l}5 \times 10^{-5} \\
9 \times 10^{-4}\end{array}$ \\
\hline $226 \mathrm{Ra}$ & $\begin{array}{l}\text { Soluble } \\
\text { Insoluble }\end{array}$ & $\begin{array}{l}3 \times 10^{-11} \\
5 \times 10^{-11}\end{array}$ & $\begin{array}{l}4 \times 10^{-7} \\
9 \times 10^{-4}\end{array}$ \\
\hline $222 \mathrm{Rn}$ & Soluble & $1 \times 10^{-7}$ & -- \\
\hline $210 \mathrm{pb}$ & $\begin{array}{l}\text { Soluble } \\
\text { Insoluble }\end{array}$ & $\begin{array}{l}1 \times 10^{-10} \\
2 \times 10^{-10}\end{array}$ & $\begin{array}{l}4 \times 10^{-6} \\
5 \times 10^{-3}\end{array}$ \\
\hline${ }^{231} \mathrm{~Pa}$ & $\begin{array}{l}\text { Soluble } \\
\text { Insoluble }\end{array}$ & $\begin{array}{l}1 \times 10-12 \\
1 \times 10-10\end{array}$ & $\begin{array}{l}3 \times 10^{-5} \\
8 \times 10^{-4}\end{array}$ \\
\hline${ }^{227} \mathrm{Ac}$ & $\begin{array}{l}\text { Soluble } \\
\text { Insoluble }\end{array}$ & $\begin{array}{l}2 \times 10^{-12} \\
3 \times 10^{-11}\end{array}$ & $\begin{array}{l}6 \times 10^{-5} \\
9 \times 10^{-3}\end{array}$ \\
\hline${ }^{234} \mathrm{Th}$ & $\begin{array}{l}\text { Soluble } \\
\text { Insoluble }\end{array}$ & $\begin{array}{l}6 \times 10^{-8} \\
3 \times 10^{-8}\end{array}$ & $\begin{array}{l}5 \times 10^{-4} \\
5 \times 10^{-4}\end{array}$ \\
\hline $234 u$ & $\begin{array}{l}\text { Soluble } \\
\text { Insolub le }\end{array}$ & $\begin{array}{l}6 \times 10-10 \\
1 \times 10-10\end{array}$ & $\begin{array}{l}9 \times 10^{-4} \\
9 \times 10^{-4}\end{array}$ \\
\hline $210_{B C}$ & $\begin{array}{l}\text { Solub le } \\
\text { Insoluble }\end{array}$ & $\begin{array}{l}6 \times 10^{-9} \\
6 \times 10^{-9}\end{array}$ & $\begin{array}{l}1 \times 10-3 \\
1 \times 10^{-3}\end{array}$ \\
\hline $210 \mathrm{po}_{0}$ & $\begin{array}{l}\text { Soluble } \\
\text { Inso lub le }\end{array}$ & $\begin{array}{l}5 \times 10^{-10} \\
2 \times 10^{-10}\end{array}$ & $\begin{array}{l}2 \times 10^{-5} \\
8 \times 10^{-4}\end{array}$ \\
\hline${ }^{223} \mathrm{Ra}$ & $\begin{array}{l}\text { Soluble } \\
\text { Insoluble }\end{array}$ & $\begin{array}{l}2 \times 10^{-9} \\
2 \times 10^{-10}\end{array}$ & $\begin{array}{l}2 \times 10^{-5} \\
1 \times 10^{-4}\end{array}$ \\
\hline
\end{tabular}


APPENDIX B

MINE GENERATED WASTES 


\section{MINE GENERATED WASTES $^{(a)}$}

\section{B.1 CHATTANOOGA SHALE MINE}

\section{Airborne Generated Wastes}

Dust level equals 0.1 to $0.15 \%$ of ore mined. Only $1 / 4$ of this is in the mine (controlled), the other $3 / 4$ is in loading and transporting. of the ore mined, $0.125 \%$ is assumed to be released as dust. The mines produce 4,550 tons/hr of ore with an average grade of $0.0065 \%$ of $\mathrm{U}_{3} \mathrm{O}_{8}$.

Controlled Dust

\section{Amount of:}

$$
\begin{aligned}
\text { dust in mines } & =(0.00125)(1 / 4)(4550 \text { ton } / \mathrm{hr}) \\
& (2000 \mathrm{lb} / \text { ton })=2843.75 \mathrm{lb} / \mathrm{hr} \\
= & \left(6.5 \times 10^{-5}\right)(2843.75)=0.185 \mathrm{lb} / \mathrm{hr} \\
\mathrm{U}_{3}{ }^{0} 8 \text { in mine dust } & (0.848)(0.185)=0.157 \mathrm{lb} / \mathrm{hr} \\
\text { uranium in mine dust }= & (0.993)(0.157)=0.156 \mathrm{lb} / \mathrm{hr} \\
238_{U} & (0.007)(0.157)=1.0 \times 10^{-3} \mathrm{lb} / \mathrm{hr} .
\end{aligned}
$$

The activity of the controllable mine dust:
$238 \mathrm{U}$
$235 \mathrm{U}$
238 daughters (13)
${ }^{235} \mathrm{U}$ daughters (10)
$0.156 \mathrm{lb} / \mathrm{hr}$
$1.0 \times 10^{-3} \mathrm{lb} / \mathrm{hr}$
trace
trace
$2.36 \times 10^{-5} \mathrm{Ci} / \mathrm{hr}$
$9.73 \times 10^{-7} \mathrm{Ci} / \mathrm{hr}$
$3.07 \times 10^{-4} \mathrm{Ci} / \mathrm{hr}$
$9.73 \times 10^{-6} \mathrm{Ci} / \mathrm{hr}$

(a) Excess significant figures are shown for some numbers and were used for computational purposes only. 


\section{Uncontrolled Dust}

Amount of:

$$
\begin{aligned}
\text { dust outside mines } & =(0.00125)(3 / 4)(4550 \mathrm{ton} / \mathrm{hr})(2000 \mathrm{lb} / \text { ton }) \\
& =8531.25 \mathrm{lb} / \mathrm{hr} \\
\mathrm{U}_{3} \mathrm{O}_{8} \text { in dust } & =0.5545 \mathrm{lb} / \mathrm{hr} \\
\text { uranium in dust } & =(0.848)(0.5545)=0.470 \mathrm{lb} / \mathrm{hr} \\
238 \mathrm{U} & =(0.993)(0.470)=0.467 \mathrm{lb} / \mathrm{hr} \\
235_{U} & =(.007)(0.470)=3.0 \times 10^{-3} \mathrm{lb} / \mathrm{hr} .
\end{aligned}
$$

The activity of the uncontrolled dust:

$\begin{array}{lcc}238 \mathrm{U} & 0.467 \mathrm{lb} / \mathrm{hr} & 7.06 \times 10^{-5} \mathrm{Ci} / \mathrm{hr} \\ 235 \mathrm{U} & 3.0 \times 10^{-3} \mathrm{lb} / \mathrm{hr} & 2.92 \times 10^{-6} \mathrm{Ci} / \mathrm{hr} \\ 238 \mathrm{U} \text { Daughters (13) } & \text { trace } & 9.18 \times 10^{-4} \mathrm{Ci} / \mathrm{hr} \\ 235 \mathrm{U} \text { Daughters }(10) & \text { trace } & 2.92 \times 10^{-5} \mathrm{Ci} / \mathrm{hr}\end{array}$

\section{Liquid Wastes}

There are 5,000 gpm of mine water removed from each mine. The average concentration of uranium in present mine water is 5 to $20 \mathrm{ppm}$. The Chattanooga shale mines have a much lower ore grade of $\mathrm{U}_{3} \mathrm{O}_{8}$ than present mines. Therefore, the amount of $\mathrm{U}_{3} \mathrm{O}_{8}$ is assumed to be $1 \mathrm{ppm}$ or $1 \mathrm{mg} / 1$ in the Chattanooga shale mine water.

Amount of :

$$
\begin{aligned}
U_{3}{ }^{0}= & 1 \mathrm{mg} / 1 \times 1 \mathrm{~g} / 1000 \mathrm{mg} \times 1 \mathrm{lb} / 454 \mathrm{~g} \\
& 3.791 / \mathrm{gal} \times 5000 \mathrm{gal} / \mathrm{min} \times 60 \mathrm{~min} / \mathrm{hr}=2.50 \mathrm{lb} / \mathrm{hr} \\
U= & (0.848)(2.5)=2.12 \mathrm{lb} / \mathrm{hr} \\
238_{U}= & (0.993)(2.124)=2.105 \mathrm{lb} / \mathrm{hr} \\
235_{U}= & (0.007)(2.124)=1.5 \times 10^{-2} \mathrm{lb} / \mathrm{hr} .
\end{aligned}
$$


The activity of the waste is:
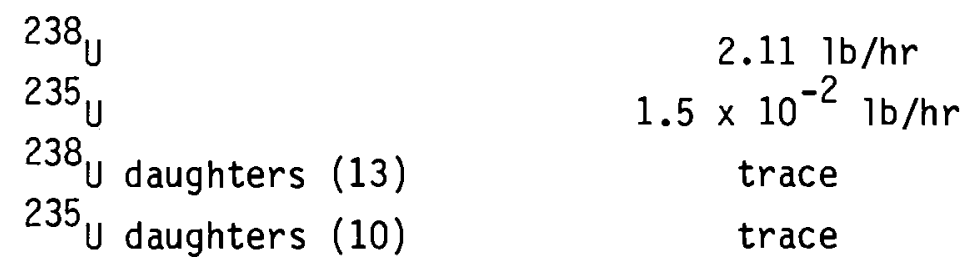

$$
\begin{aligned}
& 3.19 \times 10^{-4} \mathrm{Ci} / \mathrm{hr} \\
& 1.46 \times 10^{-5} \mathrm{Ci} / \mathrm{hr} \\
& 4.15 \times 10^{-3} \mathrm{Ci} / \mathrm{hr} \\
& 1.46 \times 10^{-4} \mathrm{Ci} / \mathrm{hr}
\end{aligned}
$$

\section{B.2 BOKAN MOUNTAIN MINE}

\section{Airborne Generated Wastes}

Dust level of uranium mines equals 0.1 to $0.15 \%$ of ore mined. These mines are located in an area of high precipitation and wet terrain and it is assumed the lower figure of $0.1 \%$ is appropriate. Only $1 / 4$ of this dust is controlled in the mines the other $3 / 4$ is uncontrolled loading and transporting dust. The mines produce 3,000 ton $/ \mathrm{hr}$ of ore with an average grade of $0.0030 \% \mathrm{U}_{3} 0_{8}$.

\section{Controlled Dust}

Amount of:

$$
\begin{array}{ll}
\text { dust in mines } & =(0.001)(1 / 4)(3000 \text { ton } / \mathrm{hr})(2000 \mathrm{lb} / \text { ton })=1500 \mathrm{lb} / \mathrm{hr} \\
\mathrm{U}_{3} 0_{8} \text { in mine dust } & =\left(3.0 \times 10^{-5}\right)(1500)=0.045 \mathrm{lb} / \mathrm{hr} \\
\text { uranium in mine dust } & =(0.848)(0.045)=0.0382 \mathrm{lb} / \mathrm{hr} \\
238_{U} & =(0.993)(0.0382)=0.0379 \mathrm{lb} / \mathrm{hr} \\
235_{U} & =(0.007)(0.0382)=3.0 \times 10^{-4} \mathrm{lb} / \mathrm{hr} .
\end{array}
$$

The activity of the controllable mine dust:

$\begin{array}{lcc}238 \mathrm{U} & 0.0379 \mathrm{lb} / \mathrm{hr} & 5.73 \times 10^{-6} \mathrm{Ci} / \mathrm{hr} \\ 235 \mathrm{U} & 3.0 \times 10^{-4} \mathrm{lb} / \mathrm{hr} & 2.92 \times 10^{-7} \mathrm{Ci} / \mathrm{hr} \\ 238 \mathrm{U} \text { daughters (13) } & \text { trace } & 7.45 \times 10^{-5} \mathrm{Ci} / \mathrm{hr} \\ 235 \mathrm{U} \text { daughters (10) } & \text { trace } & 2.92 \times 10^{-6} \mathrm{Ci} / \mathrm{hr} \\ \text { Uncontrolled Dust } & & \end{array}$

Amount of:

$$
\begin{array}{ll}
\text { dust outside mines } & =(3 / 4)(0.001)(3000 \text { ton } / \mathrm{hr})(2000 \mathrm{lb} / \mathrm{ton})=4500 \mathrm{lb} / \mathrm{hr} \\
U_{3} \mathrm{O}_{8} \text { in dust } & =\left(3.0 \times 10^{-5}\right)(4500)=0.135 \mathrm{lb} / \mathrm{hr}
\end{array}
$$




$$
\begin{array}{ll}
\text { uranium in dust } & =(0.848)(0.135)=0.1145 \mathrm{lb} / \mathrm{hr} \\
238_{U} & =(0.993)(0.1145)=0.1137 \mathrm{lb} / \mathrm{hr} \\
235_{U} & =(0.007)(0.1145)=8.0 \times 10^{-4} \mathrm{lb} / \mathrm{hr} .
\end{array}
$$

The activity of the uncontrolled dust:

$\begin{array}{lcc}238 \mathrm{U} & 0.1137 \mathrm{lb} / \mathrm{hr} & 1.72 \times 10^{-5} \mathrm{Ci} / \mathrm{hr} \\ 235 \mathrm{U} & 8.0 \times 10^{-4} \mathrm{lb} / \mathrm{hr} & 7.79 \times 10^{-7} \mathrm{Ci} / \mathrm{hr} \\ 238 \mathrm{U} \text { daughters (13) } & \text { trace } & 2.24 \times 10^{-4} \mathrm{Ci} / \mathrm{hr} \\ 235 \mathrm{U} \text { daughters }(10) & \text { trace } & 7.79 \times 10^{-6} \mathrm{Ci} / \mathrm{hr}\end{array}$

\section{Liquid Wastes}

Bokan Mountain mines can be classified as intermediate (500 to $2000 \mathrm{gpm}$ ) or dry (<500 gpm) mines in terms of water effluent. Assuming $500 \mathrm{gpm}$ as an average figure, the concentration of $\mathrm{U}_{3} \mathrm{O}_{8}$ is assumed to be $1 \mathrm{ppm}$ or $1 \mathrm{mg} / \mathrm{l}$; the same for all mines studied in this report.

Amount of:

$$
\begin{aligned}
\mathrm{U}_{3} \mathrm{O}_{8} & =1 \mathrm{mg} / 1 \times 1 \mathrm{~g} / 1000 \mathrm{mg} \times 1 \mathrm{lb} / 454 \mathrm{~g} \times 3.79 \mathrm{l} / \mathrm{gal} \\
& \times 500 \mathrm{gal} / \mathrm{min} \times 60 \mathrm{~min} / \mathrm{hr}=0.25 \mathrm{lb} / \mathrm{hr} \\
\text { uranium } & =(0.848)(0.25)=0.212 \mathrm{lb} / \mathrm{hr} \\
238_{U} & =(0.993)(0.212)=0.2105 \mathrm{lb} / \mathrm{hr} \\
235_{U} & =(0.007)(0.212)=1.5 \times 10^{-3} \mathrm{lb} / \mathrm{hr} .
\end{aligned}
$$

The activity of the water is:

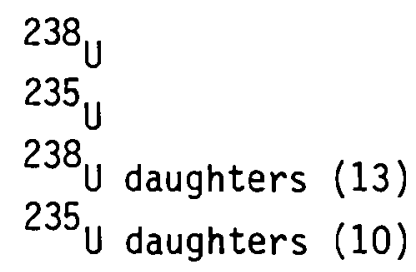

$$
\begin{aligned}
& 0.2105 \mathrm{lb} / \mathrm{hr} \\
& 1.5 \times 10^{-3} \mathrm{lb} / \mathrm{hr} \\
& \quad \operatorname{trace} \\
& \quad \text { trace }
\end{aligned}
$$

$3.18 \times 10^{-5} \mathrm{Ci} / \mathrm{hr}$ $1.46 \times 10^{-6} \mathrm{Ci} / \mathrm{hr}$ $4.14 \times 10^{-4} \mathrm{Ci} / \mathrm{hr}$ $1.46 \times 10^{-5} \mathrm{Ci} / \mathrm{hr}$ 


\section{B.3 THOMAS CALDERA MINE}

\section{Airborne Generated Wastes}

The range of airborne release factors is 0.1 to $0.15 \%$ of ore mined. The assumed value is $0.125 \%$. The concentration of $\mathrm{U}_{3} \mathrm{O}_{8}$ in this deposit is $0.003 \%$.

Amount of :

$$
\begin{array}{lll}
\text { dust } & =(0.00125)(3000 \text { ton } / \mathrm{hr})(2000 \mathrm{lb} / \text { ton })=7500 \mathrm{lb} / \mathrm{hr} \\
\mathrm{U}_{3} \mathrm{O}_{8} & =\left(3.0 \times 10^{-5}\right)(7500)=0.225 \mathrm{lb} / \mathrm{hr} \\
\text { Uranium }^{238_{\mathrm{U}}} & =(0.848)(0.225)=0.191 \mathrm{lb} / \mathrm{hr} \\
235_{\mathrm{U}} & =(0.993)(0.191)=0.189 \mathrm{lb} / \mathrm{hr} \\
& =(0.007)(0.191)=2.0 \times 10^{-3} \mathrm{lb} / \mathrm{hr} .
\end{array}
$$

The activity of the dust is:

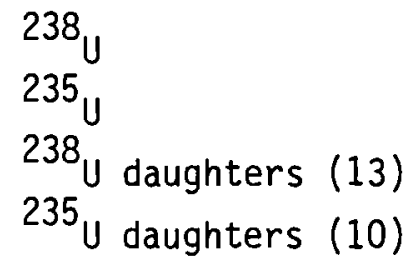

$$
\begin{gathered}
0.189 \mathrm{lb} / \mathrm{hr} \\
2.0 \times 10^{-3} \mathrm{lb} / \mathrm{hr} \\
\text { trace } \\
\text { trace }
\end{gathered}
$$

$2.86 \times 10^{-5} \mathrm{Ci} / \mathrm{hr}$ $1.95 \times 10^{-6} \mathrm{Ci} / \mathrm{hr}$ $3.72 \times 10^{-4} \mathrm{Ci} / \mathrm{hr}$ $1.95 \times 10^{-5} \mathrm{Ci} / \mathrm{hr}$

\section{Liquid Wastes}

The mine is located in an arid environment and will be assumed to be a dry mine $(<500 \mathrm{gpm})$. An average figure of $250 \mathrm{gpm}$ and a concentration of 1 ppm or $1 \mathrm{mg} / 1$ of $\mathrm{U}_{3} \mathrm{O}_{8}$ is assumed.

Amount of :

$$
\begin{aligned}
& \mathrm{U}_{3} \mathrm{O}_{8} \\
& =(1 \mathrm{mg} / 1)(1 \mathrm{~g} / 1000 \mathrm{mg})(1 \mathrm{lb} / 454 \mathrm{~g})(3.79 \mathrm{l} / \mathrm{gal}) \\
& (250 \mathrm{gal} / \mathrm{min})(60 \mathrm{~min} / \mathrm{hr})=0.125 \mathrm{lb} / \mathrm{hr} \\
& \text { uranium } \\
& =(0.848)(0.125)=0.106 \mathrm{lb} / \mathrm{hr} \\
& 238 \mathrm{U} \\
& =(0.993)(0.106)=0.105 \mathrm{lb} / \mathrm{hr} \\
& 235 \mathrm{U} \\
& =(0.007)(0.106)=1.0 \times 10^{-3} \mathrm{lb} / \mathrm{hr} \text {. }
\end{aligned}
$$


The activity of the water is:

$\begin{array}{lcc}{ }^{238} \mathrm{U} & 0.105 \mathrm{lb} / \mathrm{hr} & 1.59 \times 10^{-5} \mathrm{Ci} / \mathrm{hr} \\ { }^{235} \mathrm{U} & 1.0 \times 10^{-3} \mathrm{lb} / \mathrm{hr} & 9.73 \times 10^{-7} \mathrm{Ci} / \mathrm{hr} \\ { }^{238} \mathrm{U} \text { daughters (13) } & \text { trace } & 2.06 \times 10^{-4} \mathrm{Ci} / \mathrm{hr} \\ 235 \mathrm{U} \text { daughters (10) } & \text { trace } & 9.73 \times 10^{-6} \mathrm{Ci} / \mathrm{hr}\end{array}$

\section{B.4 FLORIDA PHOSPHATE MINE}

\section{Solid Waste}

The mining method used in this deposit is a dragline and dredge system. The ore recovered is in solution ( $30 \%$ solids) so there are no airborne effluents or dust given off. The only waste product in the mining phase is the overburden removed. The amount of overburden removed is $10,220,000$ tons/yr. The concentration of $\mathrm{U}_{3} \mathrm{O}_{8}$ contained in the removed ore is $65 \mathrm{ppm}$. The overburden is assumed to contain an average of $1 \mathrm{ppm}$ or $1 \mathrm{mg} / 1 \mathrm{U}_{3} \mathrm{O}_{8}$.

Amount of:

$$
\begin{aligned}
\text { solids }= & (10,220,000 \mathrm{ton} / \mathrm{hr})(1 \mathrm{yr} / 240 \text { days })(1 \text { day } / 24 \\
& \text { hrs })(2000 \mathrm{lb} / \text { ton })=3.55 \times 10^{6} \mathrm{lb} / \mathrm{hr} \\
= & \left(1.0 \times 10^{-6}\right)\left(3.55 \times 10^{6}\right)=3.55 \mathrm{lb} / \mathrm{hr} \\
U_{3} 0_{8} & =(0.848)(3.55)=3.01 \mathrm{lb} / \mathrm{hr} \\
\text { uranium }= & (0.993)(3.01)=2.99 \mathrm{bb} / \mathrm{hr} \\
{ }^{238} U & { }^{235} \mathrm{U}= \\
= & (0.007 \times 3.01)=2.0 \times 10^{-2} \mathrm{lb} / \mathrm{hr} .
\end{aligned}
$$

The activity of the solids is:

$\begin{array}{lcc}{ }^{238} \mathrm{U} & 2.99 \mathrm{lb} / \mathrm{hr} & 4.52 \times 10^{-4} \mathrm{Ci} / \mathrm{hr} \\ { }^{235} \mathrm{U} & 2.0 \times 10^{-2} \mathrm{lb} / \mathrm{hr} & 1.95 \times 10^{-5} \mathrm{Ci} / \mathrm{hr} \\ { }^{238} \mathrm{U} \text { daughters }(13) & \text { trace } & 5.88 \times 10^{-3} \mathrm{Ci} / \mathrm{hr} \\ { }^{235} \mathrm{U} \text { daughters }(10) & \text { trace } & 1.95 \times 10^{-4} \mathrm{Ci} / \mathrm{hr}\end{array}$




\section{APPENDIX C}

MILL GENERATED WASTES 


\section{MILL GENERATED WASTES $^{\text {(a) }}$}

\section{C.1 CHATTANOOGA SHALE MILL}

The flowsheet (Figure C.1) shows the operations of the Chattanooga shale mill. The activity levels are determined for the rates of generated wastes shown in the flowsheet.

\section{Solids Returned to Mine}

There are 454.5 tons/hr of solid tails to be returned to the mine for disposal. A very liberal estimate of the amount of $\mathrm{U}_{3} \mathrm{O}_{8}$ in the solids is $58.8 \mathrm{lb} / \mathrm{hr}$. The amount of uranium in the solids is $84.8 \%$ of that, or 49.86 $\mathrm{lb} / \mathrm{hr}$. The uranium contains ${ }^{238} U$ and ${ }^{235} U$ at a ratio of $0.993: 0.007$, thus there are $49.51 \mathrm{lb} / \mathrm{hr}{ }^{238} \mathrm{U}$ and $0.35 \mathrm{lb} / \mathrm{hr}{ }^{235} \mathrm{U}$.

The activity of the waste stream is:

$\begin{array}{lcc}238 \mathrm{U} & 49.51 \mathrm{lb} / \mathrm{hr} & 7.49 \times 10^{-3} \mathrm{Ci} / \mathrm{hr} \\ 235 \mathrm{U} & 0.35 \mathrm{lb} / \mathrm{hr} & 3.41 \times 10^{-4} \mathrm{Ci} / \mathrm{hr} \\ 238_{\mathrm{U}} & 9.74 \times 10^{-2} \mathrm{Ci} / \mathrm{hr} \\ 235_{\mathrm{U} \text { daughters }(13)} & \text { trace } & 3.41 \times 10^{-3} \mathrm{Ci} / \mathrm{hr}\end{array}$

The above waste stream is all solids and can be returned to the mine for disposal or sent to an approved site.

Crushing and Grinding Dust

Of the $57.3 \mathrm{lb} / \mathrm{hr}$ of ore in the dust, $3.7 \times 10^{-3} \mathrm{lb} / \mathrm{hr}$ are $\mathrm{U}_{3} \mathrm{O}_{8}$. The uranium content $=(0.848)\left(3.7 \times 10^{-3}\right)=3.14 \times 10^{-3} \mathrm{lb} / \mathrm{hr}$. The uranium is split between ${ }^{238} \mathrm{U}$ and ${ }^{235} \mathrm{U}$ at a ratio of $0.993: 0.007$. Thus, there are $3.12 \times 10^{-3}$ $\mathrm{lb} / \mathrm{hr}{ }^{238} \mathrm{U}$ and $2.2 \times 10^{-5} \mathrm{lb} / \mathrm{hr}{ }^{235} \mathrm{U}$.

(a) Excess significant figures are shown for some numbers and were used for computational purposes only. 


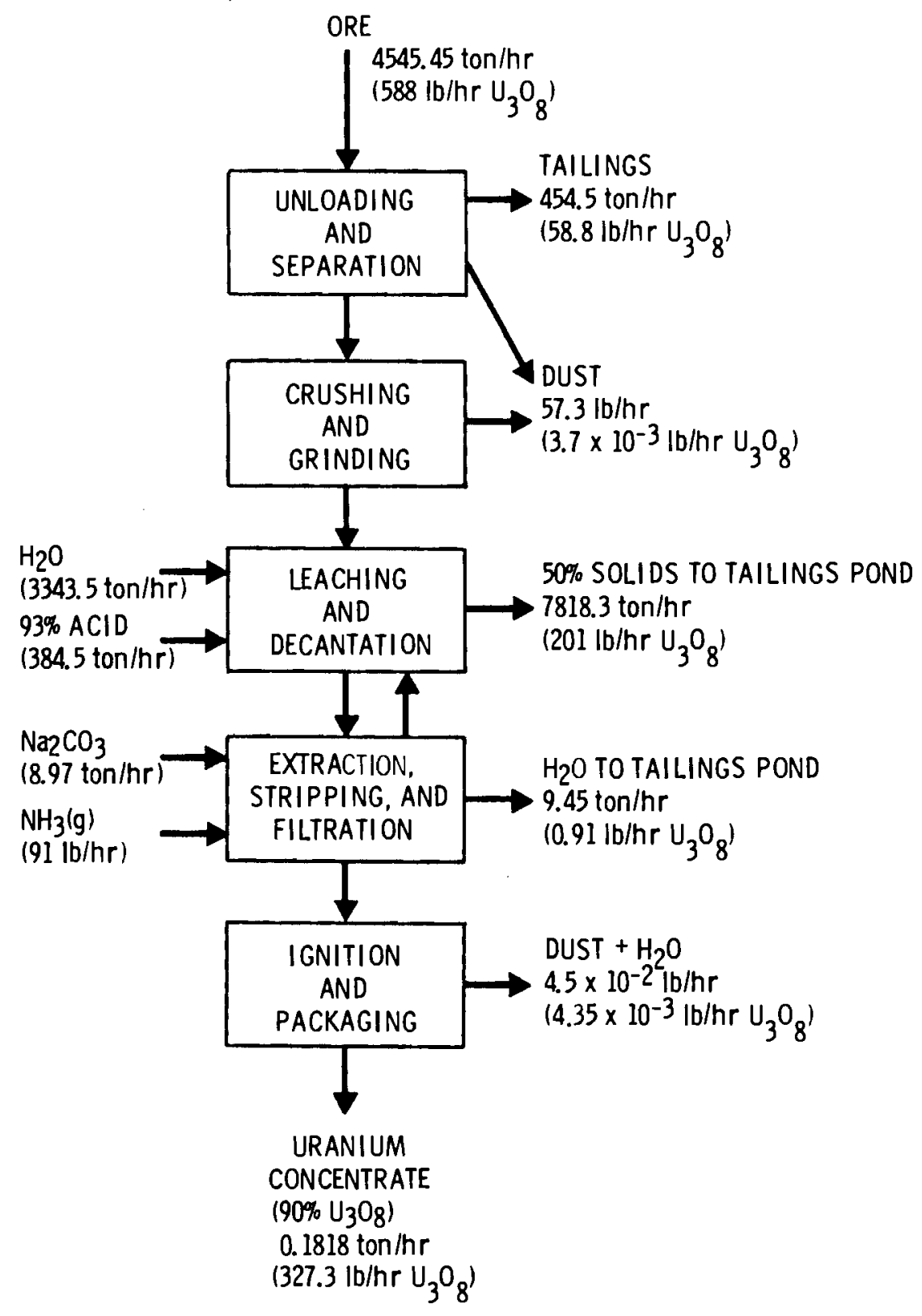

FIGURE C.1. Chattanooga Shale Mill Flowsheet

The activity of the dust stream is:

$\begin{array}{lcc}238 \mathrm{U} & 3.12 \times 10^{-3} \mathrm{lb} / \mathrm{hr} & 4.72 \times 10^{-7} \mathrm{Ci} / \mathrm{hr} \\ 235_{U} & 2.20 \times 10^{-5} \mathrm{lb} / \mathrm{hr} & 2.14 \times 10^{-8} \mathrm{Ci} / \mathrm{hr} \\ 238 \mathrm{U} \text { daughters (13) } & \text { trace } & 6.13 \times 10^{-6} \mathrm{Ci} / \mathrm{hr} \\ 235_{U} \text { daughters }(10) & \text { trace } & 2.14 \times 10^{-7} \mathrm{Ci} / \mathrm{hr}\end{array}$


Ignition and Packaging Dust

There are $4.5 \times 10^{-2} \mathrm{lb} / \mathrm{hr}$ of dust and water given off at this point in the process. The amount of $\mathrm{U}_{3} \mathrm{O}_{8}$ is $4.35 \times 10^{-3} \mathrm{lb} / \mathrm{hr}$. The uranium content $=$ $(0.848)\left(4.35 \times 10^{-3}\right)=3.69 \times 10^{-3} \mathrm{lb} / \mathrm{hr}$. This uranium is split into ${ }^{238} \mathrm{U}$ and ${ }^{235} \mathrm{U}$ at a ratio of $0.993: 0.007$. Thus, there are $3.66 \times 10^{-3} \mathrm{lb} / \mathrm{hr}$ of ${ }^{238} \mathrm{U}$ and $3.0 \times 10^{-5} \mathrm{lb} / \mathrm{hr}$ of ${ }^{235} \mathrm{U}$. The daughter products of both ${ }^{238} \mathrm{U}$ and ${ }^{235} \mathrm{U}$ have already been removed from the $\mathrm{U}_{3} 0_{8}$ except for some ${ }^{230} \mathrm{Th}$ and ${ }^{234} \mathrm{U}$ in the $238 \mathrm{U}$ decay series. Thorium-230 is assumed to have an activity level $5 \%$ of the ${ }^{238} \mathrm{U}$ and ${ }^{234} \mathrm{U}$ is assumed to have the same level as ${ }^{238} \mathrm{U}$.

The activity of the dust stream is:

$\begin{array}{lcc}238_{\mathrm{U}} & 3.66 \times 10^{-3} \mathrm{lb} / \mathrm{hr} & 5.54 \times 10^{-7} \mathrm{Ci} / \mathrm{hr} \\ 235_{\mathrm{U}} & 3.00 \times 10^{-5} \mathrm{lb} / \mathrm{hr} & 2.92 \times 10^{-8} \mathrm{Ci} / \mathrm{hr} \\ 234_{\mathrm{U}} & \text { trace } & 5.54 \times 10^{-7} \mathrm{Ci} / \mathrm{hr} \\ 230_{\mathrm{Th}} & \text { trace } & 2.77 \times 10^{-8} \mathrm{Ci} / \mathrm{hr}\end{array}$

Waste To Tailings Pond

The following streams and respective loads are sent to a tailings pond:

- leaching and decantation stream - $50 \%$ solids at a rate of 7818.3 ton/hr containing $201 \mathrm{lb} / \mathrm{hr}$ of $\mathrm{U}_{3} \mathrm{O}_{8}$ with a total flow of 15,637 gpm.

- extraction, stripping and filtration stream - 9.45 tons/hr containing $0.91 \mathrm{lb} / \mathrm{hr}$ of $\mathrm{U}_{3} \mathrm{O}_{8}$ with a total flow of $37.8 \mathrm{gpm}$.

The tatal load to the tailings pond is 7827.75 ton/hr, containing 201.91 $\mathrm{lb} / \mathrm{hr}$ of $\mathrm{U}_{3} \mathrm{O}_{8}$. The total flow to the pond is $15,675 \mathrm{gpm}$. All daughter products in entering ore are contained in the tailings pond except those emitted in dust streams, the tailings stream returned to the mine, or in the final product.

The activity of the ${ }^{238} \mathrm{U}$ daughter products in the tailings pond is determined below: 
Activity of ${ }^{238} \mathrm{U}$ daughters in:

entering ore $=\left(\begin{array}{lllll}588 & \mathrm{lb} \mathrm{U}_{3} \mathrm{O}_{8} / \mathrm{hr}\end{array}\right)\left(0.848 \mathrm{lb} \mathrm{U} / 1 \mathrm{~b} \mathrm{U} \mathrm{U}_{3} \mathrm{O}_{8}\right)$

$\left(0.993 \mathrm{lb}^{238} \mathrm{U} / \mathrm{lb} \mathrm{U}\right)\left(1.512 \times 10^{-4} \mathrm{Ci} / 1 \mathrm{~b}{ }^{238} \mathrm{U}\right)(13)$

$=9.737 \times 10^{-1} \mathrm{Ci} / \mathrm{hr}$

dust streams $=\left(6.135 \times 10^{-6}\right)+\left(5.54 \times 10^{-7}\right)+\left(2.77 \times 10^{-8}\right)$

$$
=6.72 \times 10^{-6} \mathrm{Ci} / \mathrm{hr}
$$

ore returned to mine $=9.74 \times 10^{-2} \mathrm{Ci} / \mathrm{hr}$.

The only daughters in the product are ${ }^{234} U$, with an activity level equal to ${ }^{238} \mathrm{U}$, and ${ }^{230} \mathrm{Th}$, with an activity level $5 \%$ of ${ }^{238} \mathrm{U}$. The activity level of ${ }^{238} \mathrm{U}$ is determined first; the activity level of the daughters $\left({ }^{234} \mathrm{U}+{ }^{230} \mathrm{Th}\right)$ is then calculated at $105 \%$.

Activity level of $238_{U}$

$$
\begin{aligned}
\text { in product }= & \left(327.3 \mathrm{lb} \mathrm{U}_{3} \mathrm{O}_{8} / \mathrm{hr}\right)\left(0.848 \mathrm{lb} \mathrm{U} / 1 \mathrm{~b} \mathrm{U}_{3} \mathrm{O}_{8}\right) \\
& \left(0.993 \mathrm{lb}{ }^{238} \mathrm{U} / 1 \mathrm{~b} \mathrm{U}\right)\left(1.512 \times 10^{-4} \mathrm{Ci} / 1 \mathrm{~b}{ }^{238} \mathrm{U}\right) \\
= & 4.169 \times 10^{-2} \mathrm{Ci} / \mathrm{hr}
\end{aligned}
$$

Activity level of ${ }^{238} \mathrm{U}$ daughters

$$
\begin{aligned}
\text { in product } & =(1.05)\left(4.169 \times 10^{-2} \mathrm{Ci} / \mathrm{hr}\right) \\
& =4.38 \times 10^{-2} \mathrm{Ci} / \mathrm{hr}
\end{aligned}
$$

Activity level of ${ }^{238} U$ daughters in

$$
\begin{aligned}
\text { tailings pond }= & \left(9.737 \times 10^{-1}\right)-\left(6.72 \times 10^{-6}\right)-\left(9.74 \times 10^{-2}\right) \\
& -\left(4.38 \times 10^{-2}\right) \\
= & 8.325 \times 10^{-1} \mathrm{Ci} / \mathrm{hr} .
\end{aligned}
$$

The activity of the ${ }^{235} U$ daughters in the tailings pond can be calculated due to the assumption that all of them are in the pond except those emitted as dust in the process and as solids returned to the mine. 
Activity of ${ }^{235} U$ daughters in:

entering ore $=\left(\begin{array}{lllll}588 & \mathrm{lb} \mathrm{U}_{3} \mathrm{O}_{8} / \mathrm{hr}\end{array}\right)\left(0.848 \mathrm{lb} \mathrm{U} / \mathrm{lb} \mathrm{U}_{3} \mathrm{O}_{8}\right)$

$$
\begin{aligned}
& \left(0.007 \mathrm{lb}^{235} \mathrm{U} / \mathrm{lb} \mathrm{U}\right)\left(9.73 \times 10^{-4} \mathrm{Ci} / 1 \mathrm{~b}{ }^{235} \mathrm{U}\right)(10) \\
= & 3.397 \times 10^{-2} \mathrm{Ci} / \mathrm{hr} \\
\text { dust streams }= & 2.14 \times 10^{-7} \mathrm{Ci} / \mathrm{hr} \\
\text { ore returned to mine }= & 3.41 \times 10^{-3} \mathrm{Ci} / \mathrm{hr} \\
\text { tailings pond }= & \left(3.397 \times 10^{-2}\right)-\left(2.14 \times 10^{-7}\right)-\left(3.41 \times 10^{-3}\right) \\
= & 3.056 \times 10^{-2} \mathrm{Ci} / \mathrm{hr} .
\end{aligned}
$$

The amount of uranium in tailings sent to the pond $=(0.848)(201.91)=171.22$ $\mathrm{lb} / \mathrm{hr}$. This uranium is split into ${ }^{238} U$ and ${ }^{235} U$ at a ratio of $0.993: 0.007$. Thus, there are $170.02 \mathrm{lb} / \mathrm{hr}$ of ${ }^{238} \mathrm{U}$ and $1.20 \mathrm{lb} / \mathrm{hr}$ of ${ }^{235} \mathrm{U}$.

The activity of the tailings pond is:

$\begin{array}{lcr}238 \mathrm{U} & 170.02 \mathrm{lb} / \mathrm{hr} & 2.57 \times 10^{-2} \mathrm{Ci} / \mathrm{hr} \\ 235_{\mathrm{U}} & 1.20 \mathrm{lb} / \mathrm{hr} & 1.17 \times 10^{-3} \mathrm{Ci} / \mathrm{hr} \\ 238_{\mathrm{U}} \text { daughters } & \text { trace } & 8.325 \times 10^{-1} \mathrm{Ci} / \mathrm{hr} \\ 235_{\mathrm{U}} \text { daughters } & \text { trace } & 3.056 \times 10^{-2} \mathrm{Ci} / \mathrm{hr}\end{array}$

\section{C.2 BOKAN MOUNTAIN MILL}

The flowsheet (Figure C.2) shows the operations of the Bokan Mountain mill. The activity levels are determined for the rates of generated wastes shown in the flowsheet.

Unloading, Crushing, and Grinding Dust

There are $1.67 \mathrm{ton} / \mathrm{hr}$ of ore dust. Of this, $0.10 \mathrm{bb} / \mathrm{hr}$ are $\mathrm{U}_{3} 0_{8}$. The uranium content $=(0.848)(0.10)=8.48 \times 10^{-2} \mathrm{lb} / \mathrm{hr}$. The uranium is split between ${ }^{238} U$ and $235 U$ at a ratio of $0.993: 0.007$. Thus, there are $8.42 \times$ $10^{-2} \mathrm{lb} / \mathrm{hr}{ }^{238} \mathrm{U}$ and $6.0 \times 10^{-4} \mathrm{lb} / \mathrm{hr}{ }^{235} \mathrm{U}$. 


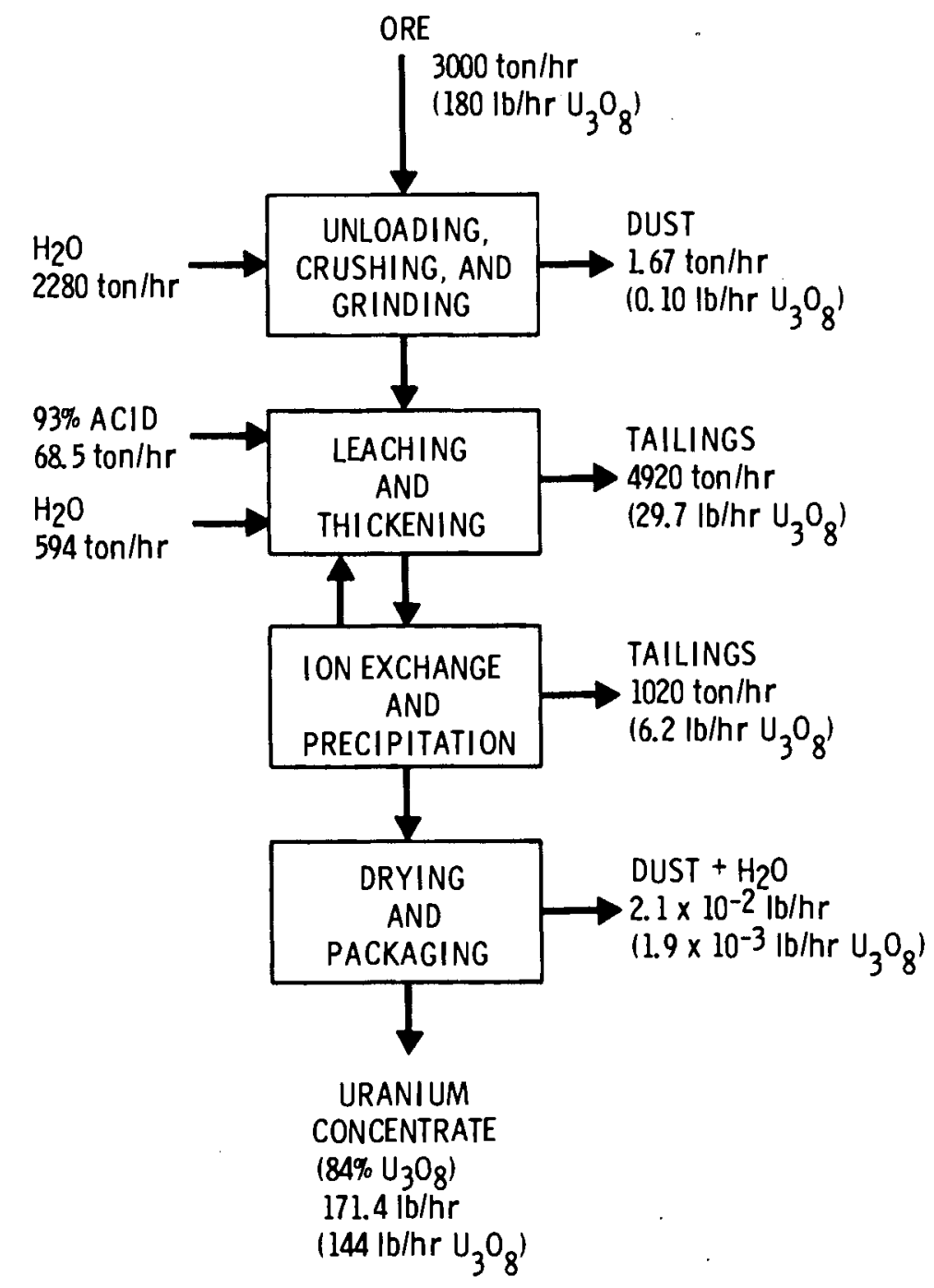

FIGURE C.2. Bokan Mountain Mi11(a)

(a) Assume $80 \%$ uranium recovery rate.

The activity of the dust stream is:
$238_{\mathrm{U}}$
$8.42 \times 10^{-2} \mathrm{lb} / \mathrm{hr}$
$1.27 \times 10^{-5} \mathrm{Ci} / \mathrm{hr}$
235
$6.00 \times 10^{-4} \mathrm{lb} / \mathrm{hr}$
$5.84 \times 10^{-7} \mathrm{Ci} / \mathrm{hr}$
$238 \mathrm{U}$ daughters (13)
trace
$1.66 \times 10^{-4} \mathrm{Ci} / \mathrm{hr}$
$235 \mathrm{U}$ daughters (10)
trace
$5.84 \times 10^{-6} \mathrm{Ci} / \mathrm{hr}$ 
Drying and Packaging Dust

There are $2.1 \times 10^{-2} \mathrm{lb} / \mathrm{hr}$ of dust and water. Of this, $1.87 \times 10^{-2} \mathrm{lb} / \mathrm{hr}$ are water and $1.9 \times 10^{-3} \mathrm{lb} / \mathrm{hr}$ are $U_{3} \mathrm{O}_{8}$. The uranium content $=(0.848)$ $\left(1.9 \times 10^{-3}\right)=1.61 \times 10^{-3} \mathrm{lb} / \mathrm{hr}$. Of this uranium, ${ }^{238} \mathrm{U}$ and ${ }^{235} \mathrm{U}$ are present at a ratio of $0.993: 0.007$. Thus, there are $1.60 \times 10^{-3} \mathrm{lb} / \mathrm{hr}$ of ${ }^{238} \mathrm{U}$ and $1.0 \times 10^{-5} \mathrm{lb} / \mathrm{hr}$ of ${ }^{235} \mathrm{U}$. All the ${ }^{235} \mathrm{U}$ daughter products have been removed from the process by this point but ${ }^{230}$ Th and ${ }^{234} \mathrm{U}$, daughter products of ${ }^{238} \mathrm{U}$, remain. The ${ }^{230}$ Th activity level is only $5 \%$ of ${ }^{238} U$ and the ${ }^{234} U$ activity level is the same as ${ }^{238} \mathrm{U}$.

The activity of the dust stream is:

$\begin{array}{lcl}{ }^{238} \mathrm{U} & 1.60 \times 10^{-3} \mathrm{lb} / \mathrm{hr} & 2.42 \times 10^{-7} \mathrm{Ci} / \mathrm{hr} \\ { }^{235_{\mathrm{U}}} & 1.00 \times 10^{-5} \mathrm{lb} / \mathrm{hr} & 9.73 \times 10^{-9} \mathrm{Ci} / \mathrm{hr} \\ { }^{234_{\mathrm{U}}} & \text { trace } & 2.42 \times 10^{-7} \mathrm{Ci} / \mathrm{hr} \\ { }^{230} \mathrm{Th} & \text { trace } & 1.21 \times 10^{-8} \mathrm{Cj} / \mathrm{hr}\end{array}$

Waste to Tailings Pond

The following streams and respective loads are sent to a tailings pond.

- leaching and thickening stream - 4,920 ton/hr containing $29.7 \mathrm{lb} / \mathrm{hr}$ $\mathrm{U}_{3} \mathrm{O}_{8}$. This stream is $58 \%$ solids and the total flow is $8,266 \mathrm{gpm}$.

- ion exchange and precipitation stream - 1,020 ton/hr containing 6.2 $\mathrm{lb} / \mathrm{hr} \mathrm{U}_{3} \mathrm{O}_{8}$ with a total flow of $4,080 \mathrm{gpm}$.

The total to the tailings pond is $5,940 \mathrm{ton} / \mathrm{hr}$ containing $35.9 \mathrm{lb} / \mathrm{hr}$ $\mathrm{U}_{3} \mathrm{O}_{8}$. The total flow to the tailings pond is $12,346 \mathrm{gpm}$. All daughter products in the entering ore are contained in the tailings pond except those emitted in the dust streams or in the final product.

The activity of the ${ }^{238} \mathrm{U}$ daughter products in the tailings pond is determined below.

Activity of ${ }^{238} \mathrm{U}$ daughters in:

$$
\begin{aligned}
\text { entering ore } & =(180)(0.848)(0.993)\left(1.512 \times 10^{-4}\right)(1) \\
& =2.981 \times 10^{-1} \mathrm{Ci} / \mathrm{hr}
\end{aligned}
$$




$$
\begin{aligned}
\text { dust streams } & =\left(1.66 \times 10^{-4}\right)+\left(2.42 \times 10^{-7}\right)+\left(1.21 \times 10^{-8}\right) \\
& =1.662 \times 10^{-4} \mathrm{Ci} / \mathrm{hr}
\end{aligned}
$$

The only ${ }^{238} \mathrm{U}$ daughters in the final product are ${ }^{234} \mathrm{U}$ and ${ }^{230}$ Th. The activity level of ${ }^{238} \mathrm{U}$ is determined first; the activity level of the daughters $\left({ }^{238} U+\right.$ ${ }^{230} \mathrm{Th}$ ) is then calculated at $105 \%$.

Activity of ${ }^{238} \mathrm{U}$ daughters in:

$$
\begin{aligned}
\text { product } & =(144)(0.848)(0.993)\left(1.512 \times 10^{-4}\right)(1.05) \\
& =1.93 \times 10^{-2} \mathrm{Ci} / \mathrm{hr} \\
\text { tailings pond } & =\left(2.981 \times 10^{-1}\right)-\left(1.662 \times 10^{-4}\right)-\left(1.93 \times 10^{-2}\right) \\
& =2.79 \times 10^{-1} \mathrm{Ci} / \mathrm{hr} .
\end{aligned}
$$

The activity of the ${ }^{235} \mathrm{U}$ daughters in the tailings pond can be calculated due to the assumption that all of the daughter products are in the tailings pond except those emitted with the dust stream. The activity of the $235 \mathrm{U}$ daughters is determined below.

Activity of ${ }^{235} \mathrm{U}$ daughters in:

$$
\begin{aligned}
\text { entering ore } & =(152.64)(0.007)\left(9.732 \times 10^{-4}\right)(10) \\
& =1.0398 \times 10^{-2} \mathrm{Ci} / \mathrm{hr} \\
\text { dust stream } & =5.84 \times 10^{-6} \mathrm{Ci} / \mathrm{hr} \\
\text { tailings pond } & =\left(1.0398 \times 10^{-2}\right)-\left(5.84 \times 10^{-6}\right) \\
& =1.039 \times 10^{-2} \mathrm{Ci} / \mathrm{hr} .
\end{aligned}
$$

The amount of ${ }^{238} U$ in the tailings pond $=(35.9)(0.848)(0.993)=30.23$ $\mathrm{lb} / \mathrm{hr}$. The amount of ${ }^{235} \mathrm{U}$ in the tailings pond $=(35.9)(0.848)(0.007)=$ $0.213 \mathrm{lb} / \mathrm{hr}$. 
The activity of the tailings pond is:

$\begin{array}{lcl}238 \mathrm{U} & 30.23 \mathrm{lb} / \mathrm{hr} & 4.57 \times 10^{-3} \mathrm{Ci} / \mathrm{hr} \\ 235 \mathrm{U} & 0.213 \mathrm{lb} / \mathrm{hr} & 2.07 \times 10^{-4} \mathrm{Ci} / \mathrm{hr} \\ 238 \mathrm{U} \text { daughters } & \text { trace } & 2.79 \times 10^{-1} \mathrm{Ci} / \mathrm{hr} \\ 235 \mathrm{U} \text { daughters } & \text { trace } & 1.039 \times 10^{-2} \mathrm{Ci} / \mathrm{hr}\end{array}$

\section{C.3 THOMAS CALDERA MILL}

The flowsheet (Figure C.3) shows the operations at Thomas Caldera. The activity levels are determined for the rates of generated wastes shown in the flowsheet.

Unloading and Storage Dust

Of the $1.67 \mathrm{ton} / \mathrm{hr}$ of ore dust, $0.10 \mathrm{lb} / \mathrm{hr}$ are $\mathrm{U}_{3} 0_{8}$. The uranium content $=(0.848)(0.10)=8.48 \times 10^{-2} \mathrm{lb} / \mathrm{hr}$. The uranium is split between ${ }^{238} \mathrm{U}$ and ${ }^{235} \mathrm{U}$ at a ratio of $0.993: 0.007$. Thus, there are $8.42 \times 10^{-2} \mathrm{lb} / \mathrm{hr}$ $238 \mathrm{U}$ and $6.0 \times 10^{-4} \mathrm{ib} / \mathrm{hr}{ }^{235} \mathrm{U}$.

The activity of the dust stream is:

$\begin{array}{lcc}238 \mathrm{U} & 8.42 \times 10^{-2} \mathrm{lb} / \mathrm{hr} & 1.27 \times 10^{-5} \mathrm{Ci} / \mathrm{hr} \\ 235 \mathrm{U} & 6.00 \times 10^{-4} \mathrm{lb} / \mathrm{hr} & 5.84 \times 10^{-7} \mathrm{Ci} / \mathrm{hr} \\ 238 \mathrm{U} \text { daughters (13) } & \text { trace } & 1.66 \times 10^{-4} \mathrm{Ci} / \mathrm{hr} \\ 235 \mathrm{U} \text { daughters (10) } & \text { trace } & 5.84 \times 10^{-6} \mathrm{Ci} / \mathrm{hr}\end{array}$

Crushing and Grinding Dust

Of the $866.7 \mathrm{lb} / \mathrm{hr}$ of ore dust, $2.6 \times 10^{-2} \mathrm{lb} / \mathrm{hr}$ are $\mathrm{U}_{3} \mathrm{O}_{8}$. The uranium content $(0.848)\left(2.6 \times 10^{-2}\right)=2.2 \times 10^{-2} \mathrm{lb} / \mathrm{hr}$. The uranium is split between ${ }^{238} U$ and ${ }^{235} U$ at a ratio of $0.993: 0.007$. Therefore, there are $2.18 \times 10^{-2}$ $\mathrm{lb} / \mathrm{hr}$ of ${ }^{238} \mathrm{U}$ and $2.0 \times 10^{-4} \mathrm{lb} / \mathrm{hr}$ of ${ }^{235} \mathrm{U}$. 


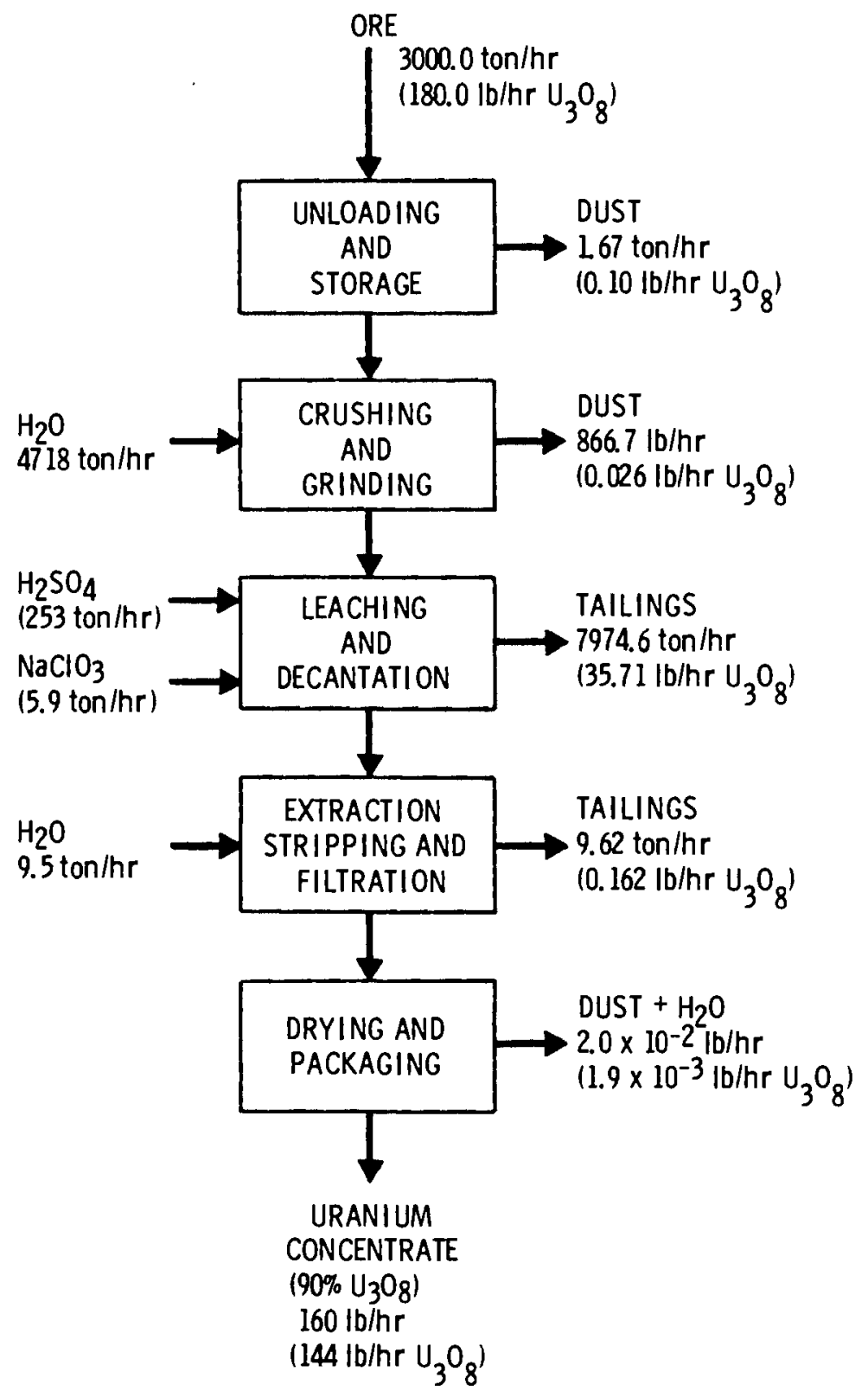

FIGURE C.3. Thomas Caldera Mill Flowsheet (a)

(a) Assume $80 \%$ uranium recovery rate. 
The activity of this dust stream is:

$\begin{array}{lcc}238_{U} & 2.18 \times 10^{-2} \mathrm{lb} / \mathrm{hr} & 3.30 \times 10^{-6} \mathrm{Ci} / \mathrm{hr} \\ 235_{U} & 2.00 \times 10^{-4} \mathrm{lb} / \mathrm{hr} & 1.95 \times 10^{-7} \mathrm{Ci} / \mathrm{hr} \\ { }^{238_{U}} & \text { trace } & 4.29 \times 10^{-5} \mathrm{Ci} / \mathrm{hr} \\ 235_{U} \text { daughters (13) } & \text { trace } & 1.95 \times 10^{-6} \mathrm{Ci} / \mathrm{hr}\end{array}$

Drying and Packaging Dust

There are $2.0 \times 10^{-2} \mathrm{lb} / \mathrm{hr}$ of dust and water. Of this, $1.79 \times 10^{-2} \mathrm{lb} / \mathrm{hr}$ are water and $1.9 \times 10^{-3} \mathrm{lb} / \mathrm{hr}$ are $\mathrm{U}_{3} \mathrm{O}_{8}$. The uranium content $=(0.848)$ $\left(1.9 \times 10^{-3}\right)=1.61 \times 10^{-3} \mathrm{lb} / \mathrm{hr}$. Of this uranium, ${ }^{238} U$ and ${ }^{235} \mathrm{U}$ are present at a ratio of $0.993: 0.007$. Thus, there are $1.60 \times 10^{-3} \mathrm{lb} / \mathrm{hr}{ }^{238} \mathrm{U}$ and $1.0 \times$ $10^{-5} \mathrm{lb} / \mathrm{hr}{ }^{235} \mathrm{U}$. All the daughter products of ${ }^{235} \mathrm{U}$ have been removed from the process by this point but ${ }^{230}$ Th and ${ }^{234} \mathrm{U}$, daughter products of ${ }^{238} \mathrm{U}$, remain. The ${ }^{230}$ Th activity level is only $5 \%$ of ${ }^{238} \mathrm{U}$; the ${ }^{234} \mathrm{U}$ activity level is the same as ${ }^{238} \mathrm{U}$.

The activity of the dust stream is:

$\begin{array}{lcc}{ }^{238} \mathrm{U} & 1.60 \times 10^{-3} \mathrm{lb} / \mathrm{hr} & 2.42 \times 10^{-7} \mathrm{Ci} / \mathrm{hr} \\ { }^{235} \mathrm{U} & 1.00 \times 10^{-5} \mathrm{lb} / \mathrm{hr} & 9.73 \times 10^{-9} \mathrm{Ci} / \mathrm{hr} \\ { }^{234} \mathrm{U} & \text { trace } & 2.42 \times 10^{-7} \mathrm{Ci} / \mathrm{hr} \\ { }^{230} \mathrm{Th} & \text { trace } & 1.21 \times 10^{-8} \mathrm{Ci} / \mathrm{hr}\end{array}$

\section{Waste to Tailings Pond}

The following streams and respective loads are sent to a tailings pond.

- leaching and decantation stream - 7974.6 ton/hr containing 35.71 $\mathrm{lb} / \mathrm{hr} \mathrm{U}_{3} \mathrm{O}_{8}$ with a total flow of $15,949 \mathrm{gpm}$.

- extraction, stripping, and filtration - 9.62 ton/hr containing 0.162 $\mathrm{lb} / \mathrm{hr} \mathrm{U}_{3} \mathrm{O}_{8}$ with a total flow of $38.5 \mathrm{gpm}$. 
The total load to the tailings pond $=7984.2 \mathrm{ton} / \mathrm{hr}$ containing 35.87 $\mathrm{lb} / \mathrm{hr} \mathrm{U}_{3} \mathrm{O}_{8}$. The total flow to the pond is $15,987 \mathrm{gpm}$. All daughter products in the entering ore are contained in the tailings pond except those emitted in the dust streams or in the final product.

The activity of the ${ }^{238} U$ daughters in the tailings pond is determined below.

Activity of ${ }^{238} \mathrm{U}$ daughters in:

$$
\begin{aligned}
\text { entering ore }= & (180)(0.848)(0.993)\left(1.512 \times 10^{-4}\right)(13) \\
= & 2.981 \times 10^{-1} \mathrm{Ci} / \mathrm{hr} \\
\text { dust streams }= & \left(1.66 \times 10^{-4}\right)+\left(4.29 \times 10^{-5}\right)+\left(2.42 \times 10^{-7}\right) \\
& +\left(1.21 \times 10^{-8}\right)=2.09 \times 10^{-4} \mathrm{Ci} / \mathrm{hr} .
\end{aligned}
$$

Only ${ }^{234} \mathrm{U}$ and ${ }^{230}$ Th remain as daughter products in the final product. The activity level of ${ }^{238} U$ is determined; then the activity level of the daughters is calculated at $105 \%$.

$$
\begin{aligned}
& \text { Activity of }{ }^{238} \mathrm{U} \text { daughters in: } \\
& \text { product }=(144)(0.848)(0.993)\left(1.512 \times 10^{-4}\right)(1.05) \\
& =1.93 \times 10^{-2} \mathrm{Ci} / \mathrm{hr} \\
& \text { tailings pond }=\left(2.981 \times 10^{-1}\right)-\left(2.09 \times 10^{-4}\right)-\left(1.93 \times 10^{-2}\right) \\
& =2.79 \times 10^{-1} \mathrm{Ci} / \mathrm{hr} \text {. }
\end{aligned}
$$

The activity of the ${ }^{235} U$ daughters in the tailings pond can be calculated due to the assumption that all of the daughter products are in the pond except those emitted with the dust streams. This activity is determined below.

$$
\begin{aligned}
\text { Activity of }{ }^{235} U \text { daughters in: } \\
\text { entering ore }=(180)(0.848)(0.007)\left(9.732 \times 10^{-4}\right)(10) \\
=1.0398 \times 10^{-2} \mathrm{Ci} / \mathrm{hr}
\end{aligned}
$$




$$
\begin{aligned}
\text { dust streams } & =\left(5.84 \times 10^{-6}\right)+\left(1.95 \times 10^{-6}\right) \\
& =7.79 \times 10^{-6} \mathrm{Ci} / \mathrm{hr} \\
\text { tailings pond } & =\left(1.0398 \times 10^{-2}\right)-\left(7.79 \times 10^{-6}\right) \\
& =1.039 \times 10^{-2} \mathrm{Ci} / \mathrm{hr} .
\end{aligned}
$$

The amount of ${ }^{238} U$ in the tailings pond $=(35.87)(0.848)(0.933)=30.20$ $\mathrm{lb} / \mathrm{hr}$. The amount of ${ }^{235} \mathrm{U}=(35.87)(0.848)(0.007)=0.218 \mathrm{lb} / \mathrm{hr}$.

The activity of the tailings pond is:

$\begin{array}{lcc}{ }^{238} \mathrm{U} & 30.20 \mathrm{lb} / \mathrm{hr} & 4.57 \times 10^{-3} \mathrm{Ci} / \mathrm{hr} \\ 235_{\mathrm{U}} & 0.218 \mathrm{lb} / \mathrm{hr} & 2.12 \times 10^{-4} \mathrm{Ci} / \mathrm{hr} \\ 238_{\mathrm{U}} \text { daughters } & \text { trace } & 2.79 \times 10^{-1} \mathrm{Ci} / \mathrm{hr} \\ 235_{\mathrm{U} \text { daughters }} & \text { trace } & 1.04 \times 10^{-2} \mathrm{Ci} / \mathrm{hr}\end{array}$

\section{C.4. FLORIDA PHOSPHATE MILL}

The flowsheet (Figure C.4) shows the operations of the Florida mill. The activity levels are determined for the rates of generated wastes shown in the flowsheet.

\section{Dust From Drying and Packaging}

There are $7.2 \times 10^{-3} \mathrm{lb} / \mathrm{hr}$ of dust and water given off at this point in the process. The amount of $\mathrm{U}_{3} \mathrm{O}_{8}$ is $6.5 \times 10^{-4} \mathrm{lb} / \mathrm{hr}$. The uranium content $=$ $(0.848)\left(6.5 \times 10^{-4}\right)=5.5 \times 10^{-4} \mathrm{lb} / \mathrm{hr}$. The uranium is split into ${ }^{238} \mathrm{U}$ and $235 \mathrm{U}$ at a ratio of $0.993: 0.007$. Thus, there are $5.46 \times 10^{-4} \mathrm{lb} / \mathrm{hr}{ }^{238} \mathrm{U}$ and $3.85 \times 10^{-6} \mathrm{lb} / \mathrm{hr}{ }^{235} \mathrm{U}$. At this point in the process the daughter products of both ${ }^{238} \mathrm{U}$ and ${ }^{235} \mathrm{U}$ have already been removed from the $\mathrm{U}_{3} \mathrm{O}_{8}$ except for some ${ }^{230}$ Th and ${ }^{234} \mathrm{U}$ in the ${ }^{238} \mathrm{U}$ decay series. ${ }^{230} \mathrm{Th}$ is assumed to have an activity level of $5 \%$ of ${ }^{238} U$ and ${ }^{234} U$ is assumed to have the same activity level as ${ }^{238} U$. 


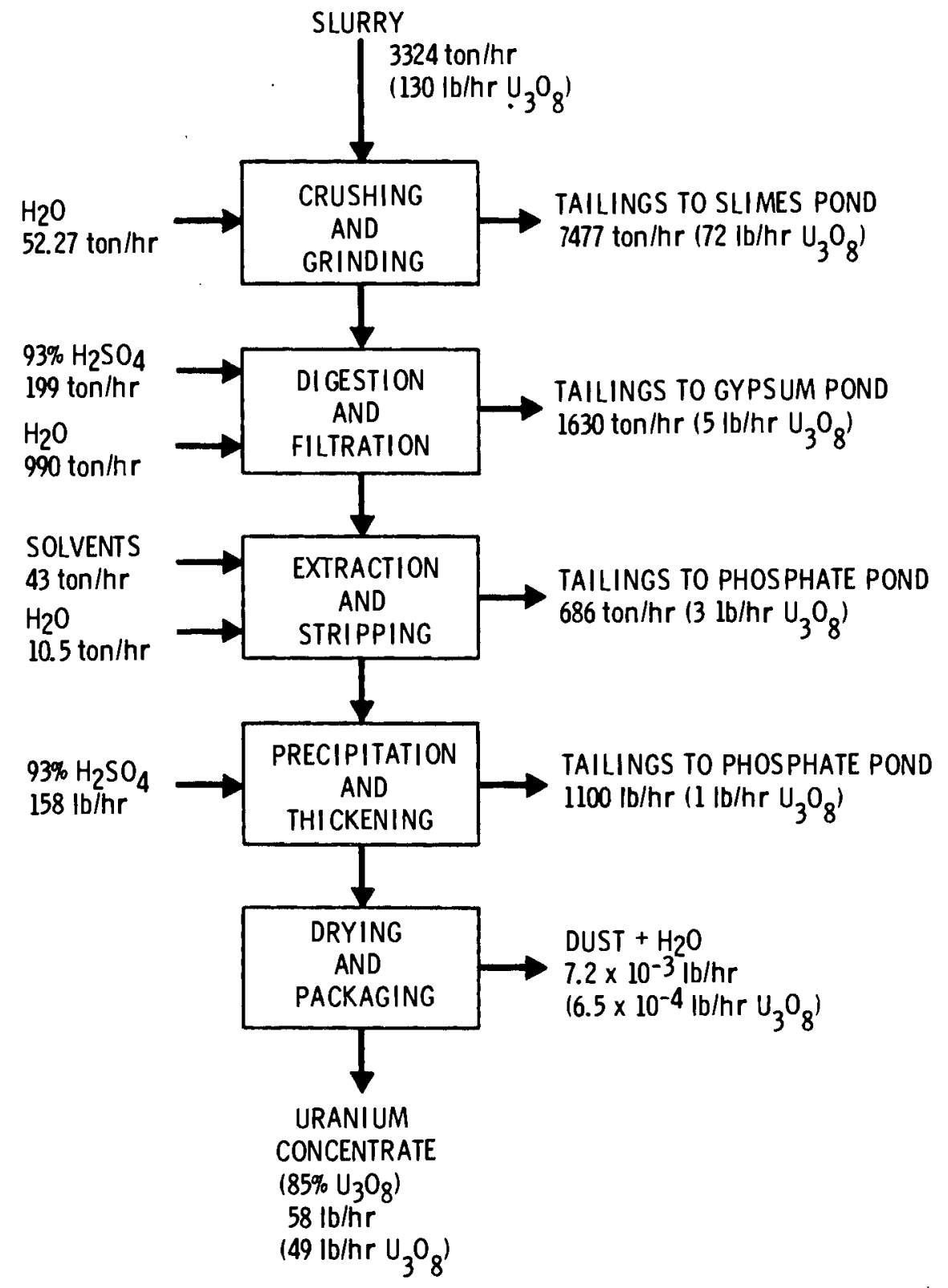

FIGURE C.4. Florida Phosphate Mill Flowsheet 
The activity of the dust stream is:

$\begin{array}{lrr}{ }^{238} \mathrm{U} & 5.46 \times 10^{-4} \mathrm{lb} / \mathrm{hr} & 8.26 \times 10^{-8} \mathrm{Ci} / \mathrm{hr} \\ { }^{235} \mathrm{U} & 3.85 \times 10^{-6} \mathrm{lb} / \mathrm{hr} & 3.75 \times 10^{-9} \mathrm{Ci} / \mathrm{hr} \\ { }^{230} \mathrm{Th} & \text { trace } & 4.13 \times 10^{-9} \mathrm{Ci} / \mathrm{hr} \\ { }^{234} \mathrm{U} & \text { trace } & 8.26 \times 10^{-8} \mathrm{ci} / \mathrm{hr}\end{array}$

Slimes Tailings

There are 7,477 ton/hr of liquid effluents in the slimes tailings stream. This flow is $29,200 \mathrm{gpm}$ and $4 \%$ solids. It contains $72 \mathrm{lb} / \mathrm{hr} \mathrm{U} \mathrm{U}_{3} \mathrm{O}_{8}$. The amount of uranium in this stream $=(0.848)(72)=61.06 \mathrm{lb} / \mathrm{hr}$. The ratio of $238_{\mathrm{U}}$ to ${ }^{235} \mathrm{U}$ is $0.993: 0.007$ so there are $60.63 \mathrm{lb} / \mathrm{hr}{ }^{238} \mathrm{U}$ and $0.43 \mathrm{lb} / \mathrm{hr}{ }^{235} \mathrm{U}$ in the stream. In order to apportion the daughter products' activities among the tailings streams a complete activity balance must be performed. The daughter products in the entering ore, uranium concentrate product, and dust must be calculated first. Then the remaining daughter products will be "assigned" to the four streams on a weighted average of their $\mathrm{U}_{3} \mathrm{O}_{8}$.

- daughter product activity in entering ore:

amount of:

$$
\begin{aligned}
\text { uranium } & =(0.848)(130) \\
& =110.241 \mathrm{~b} / \mathrm{hr} U \\
238_{U} & =(0.993)(110.24) \\
& =109.47 \mathrm{lb} / \mathrm{hr}^{238} \mathrm{U} \\
235_{U} & =(0.007)(110.24) \\
& =0.771 \mathrm{~b} / \mathrm{hr}^{235} \mathrm{U}
\end{aligned}
$$

activity of:

$$
\begin{aligned}
{ }^{238} U & =(109.47)\left(1.5126812 \times 10^{-4}\right) \\
& =1.656 \times 10^{-2} \mathrm{Ci} / \mathrm{hr}
\end{aligned}
$$




$$
\begin{aligned}
{ }^{238} U \text { daughters } & =(13)\left(1.656 \times 10^{-2}\right) \\
& =2.1527 \times 10^{-1} \mathrm{Ci} / \mathrm{hr} \\
{ }^{235} \mathrm{U} & =(0.77)\left(9.7316456 \times 10^{-4}\right) \\
& =7.493 \times 10^{-4} \mathrm{Ci} / \mathrm{hr} \\
235_{U} \text { daughters } & =(10)\left(7.493 \times 10^{-4}\right) \\
& =7.493 \times 10^{-3} \mathrm{Ci} / \mathrm{hr} .
\end{aligned}
$$

- daughter product activity in uranium concentrate product:

amount of:

$$
\begin{aligned}
\text { uranium } & =(49)(0.848) \\
& =41.55 \mathrm{lb} / \mathrm{hr} \mathrm{U} \\
238 \mathrm{U} & =(0.993)(41.55) \\
& =41.26 \mathrm{lb} / \mathrm{hr} 238 \mathrm{U} \\
\text { activity of: } \quad{ }^{238} \mathrm{U} & =(41.26)\left(1.5126812 \times 10^{-4}\right) \\
& =6.24 \times 10^{-3} \mathrm{Ci} / \mathrm{hr} .
\end{aligned}
$$

The only daughter products in the $U_{3} 0_{8}$ are ${ }^{230}$ Th and ${ }^{234} U$ from the ${ }^{238} U$ decay chain.

activity of :

$$
\begin{aligned}
{ }^{238} \mathrm{U} \text { daughters } & =(1.05)\left(6.24 \times 10^{-3}\right) \\
& =6.55 \times 10^{-3} \mathrm{Ci} / \mathrm{hr} .
\end{aligned}
$$

- daughter product activity in dust stream:

$$
{ }^{238} \mathrm{U} \text { daughters }=8.67 \times 10^{-3} \mathrm{Ci} / \mathrm{hr} \text {. }
$$

- daughter products in tailings streams - All entering ${ }^{235} \mathrm{U}$ daughters go to tailings streams: 
activity of:

$$
\begin{aligned}
{ }^{235} \mathrm{U} \text { daughters }= & 7.493 \times 10^{-3} \mathrm{Ci} / \mathrm{hr} \\
{ }^{238} \mathrm{U} \text { daughters }= & \left(2.1527 \times 10^{-1}\right)-\left(6.55 \times 10^{-3}\right) \\
& -\left(8.76 \times 10^{-8}\right) \\
= & 2.0872 \times 10^{-1} \mathrm{Ci} / \mathrm{hr} .
\end{aligned}
$$

The activity levels are assumed to be apportioned among the tailings streams according to the $\mathrm{U}_{3} \mathrm{O}_{8}$ content. The total amount of $\mathrm{U}_{3} \mathrm{O}_{8}$ to all ponds is $81 \mathrm{lb} / \mathrm{hr}$. Therefore, the activity level of ${ }^{238} \mathrm{U}$ daughters in the slimes stream is $(72 / 81)\left(2.087 \times 10^{-1}\right)=1.855 \times 10^{-1} \mathrm{Ci} / \mathrm{hr}$ and the activity level of ${ }^{235} \mathrm{U}$ in the slimes stream is $(72 / 81)\left(7.493 \times 10^{-3}\right)=6.66 \times 10^{-3} \mathrm{Ci} / \mathrm{hr}$.

The activity of the slimes tailings stream is:

$\begin{array}{lcl}238 \mathrm{U} & 60.63 \mathrm{lb} / \mathrm{hr} & 9.17 \times 10^{-3} \mathrm{Ci} / \mathrm{hr} \\ 235_{\mathrm{U}} & 0.43 \mathrm{lb} / \mathrm{hr} & 4.19 \times 10^{-4} \mathrm{Ci} / \mathrm{hr} \\ 238_{\mathrm{U}} \text { daughters } & \text { trace } & 1.855 \times 10^{-1} \mathrm{Ci} / \mathrm{hr} \\ 235_{\mathrm{U} \text { daughters }} & \text { trace } & 6.66 \times 10^{-3} \mathrm{Ci} / \mathrm{hr}\end{array}$

\section{Gypsum Tailings}

There are 1,630 ton/hr of $50 \%$ solids in the gypsum tailings stream. This flow is $4,700 \mathrm{gpm}$ and contains $5 \mathrm{lb} / \mathrm{hr}$ of $\mathrm{U}_{3} \mathrm{O}_{8}$. The uranium content = $(0.848)(5)=4.24 \mathrm{lb} / \mathrm{hr}$. The ratio of $238_{\mathrm{U}}{ }^{3}$ to ${ }^{235} \mathrm{U}$ is $0.993: 0.007$ so there are $4.21 \mathrm{lb} / \mathrm{hr}$ of ${ }^{238} \mathrm{U}$ and $2.97 \times 10^{-2} \mathrm{lb} / \mathrm{hr}$ of $235 \mathrm{U}$.

The activity level of the ${ }^{238} \mathrm{U}$ daughter products are $(5 / 81)(2.0872 \mathrm{x}$ $\left.10^{-1}\right)=1.29 \times 10^{-2} \mathrm{Ci} / \mathrm{hr}$. The activity level of the ${ }^{235} \mathrm{U}$ daughter products are $(5 / 81)\left(7.493 \times 10^{-3}\right)=4.63 \times 10^{-4} \mathrm{Ci} / \mathrm{hr}$.

The activity of the gypsum tailings stream is:
$238_{\mathrm{U}}$
$4.21 \mathrm{lb} / \mathrm{hr}$
$6.37 \times 10^{-4} \mathrm{Ci} / \mathrm{hr}$
$235 \mathrm{U}$
$2.97 \times 10^{-2} \mathrm{lb} / \mathrm{hr}$
$2.89 \times 10^{-5} \mathrm{Ci} / \mathrm{hr}$
$238_{\mathrm{U}}$ daughters
trace
$1.29 \times 10^{-2} \mathrm{Ci} / \mathrm{hr}$
$235 \mathrm{U}$ daughters
trace
$4.63 \times 10^{-4} \mathrm{Ci} / \mathrm{hr}$ 


\section{Tailings to Phosphate Pond}

The following streams and respective loads are sent to the phosphate pond:

- extraction and stripping stream - 686 ton/hr containing $3 \mathrm{lb} / \mathrm{hr}$ $\mathrm{U}_{3} \mathrm{O}_{8}$ with a total flow of $2,370 \mathrm{gpm}$ ( $22 \%$ solids)

- precipitation and thickening stream - 1,100 1b/hr containing $1 \mathrm{lb} / \mathrm{hr}$ $\mathrm{U}_{3} \mathrm{O}_{8}$ with a total flow of $2.2 \mathrm{gpm}$.

The total load to the tailings pond is 686.6 ton/hr, containing $4 \mathrm{lb} / \mathrm{hr}$ $\mathrm{U}_{3} \mathrm{O}_{8}$. The total flow to the pond is $2372.2 \mathrm{gpm}$. The amount of uranium into the pond $=(0.848)(4)=3.39 \mathrm{lb} / \mathrm{hr}$. The ratio of ${ }^{238} \mathrm{U}$ to ${ }^{235} \mathrm{U}$ in the uranium is 0.993:0.007. Therefore, there are $3.37 \mathrm{lb} / \mathrm{hr}$ of ${ }^{238} \mathrm{U}$ and $2.0 \times$ $10^{-2} \mathrm{lb} / \mathrm{hr}$ of ${ }^{235} \mathrm{U}$.

The activity level of the ${ }^{238} U$ daughter products $=(4 / 81)(2.0872 \times$ $\left.10^{-1}\right)=1.03 \times 10^{-2} \mathrm{Ci} / \mathrm{hr}$. The activity level of the ${ }^{235} \mathrm{U}$ daughter products $=$ $(4 / 81)\left(7.493 \times 10^{-3}\right)=3.70 \times 10^{-4} \mathrm{Ci} / \mathrm{hr}$.

The activity of the phosphate pond is:

$\begin{array}{lcc}{ }^{238} \mathrm{U} & 3.37 \mathrm{lb} / \mathrm{hr} & 5.10 \times 10^{-4} \mathrm{Ci} / \mathrm{hr} \\ { }^{235} \mathrm{U} & 2.0 \times 10^{-2} \mathrm{lb} / \mathrm{hr} & 1.95 \times 10^{-5} \mathrm{Ci} / \mathrm{hr} \\ { }^{238} \mathrm{U} \text { daughters } & \text { trace } & 1.03 \times 10^{-2} \mathrm{Ci} / \mathrm{hr} \\ 235_{\mathrm{U} \text { daughters }} & \text { trace } & 3.70 \times 10^{-4} \mathrm{Ci} / \mathrm{hr}\end{array}$




\section{DISTRIBUTION}

No. of

Copies

\section{OFFSITE}

A.A. Churm

DOE Patent Division

9800 S. Cass Ave.

Argonne, IL 60439

R.W. Ramsey

DOE Division of Environmental and

Safety Engineering

Washington, DC 20545

W.E. Mott

DOE Division of Environmental and Safety Engineering

Washington, DC 20545

J. Counts

DOE Division of Environmental and

Safety Engineering

Washington, DC 20545

27 DOE Technical Information Center

Bobby $\mathrm{Clark}$

Flanders Filters

P.0. Box 1219

Washington, NC 27889

J.H. Cavendish

National Lead Company

of Ohio

P.0. Box 39158

Cincinnati, OH 45239

Frank E. Driggers

El DuPont

Savannah River Laboratories

Aiken, SC 29801
No. of

Copies

D.R. Everhart

Manager

Grand Junction Operation

Office

U.S. Dept. of Energy

Grand Junction, CO 81502

Dr. T.W. Offield

U.S. Geological Survey

Federal Center

Box 25046

Mail Stop 916

Denver, CO 80225

J.A. Patterson

Director of Resource

Assessment Operations

12th \& Pennsylvania Ave. N.W.

Mail Stop 6521, RA 224

Washington, DC 20461

Roy Post

University of Arizona

Department of Nuclear

Engineering

Tucson, AZ 85721

W.M. Shaffer III

Acfg. Director

Fuel Cycle Project Office

Savannah River Operations

Office

P.0. Box A

Aiken, SC 29801

M.H. Staatz

U.S. Geological Survey

1711 Illinois Street

Room 327

Golden, C0 80401 
No. of

Copies

ONSITE

DOE Richland Operations office

H. E. Ransom

23 Pacific Northwest Laboratory

D. E. Blahnik

C. H. Bloomster

D. E. Deonigi
No. of

Copies

D. A. Dingee

R. M. Fleischman

V. E. Lee

W. V. Loscutoff

R. C. Liikala

S. A. Weakley (5)

L. W. Long

L. D. Willians

J. K. Young

Technical Information Files (5)

Publishing Coordination KE (2) 